

Digitized by the Internet Archive in 2007 with funding from Microsoft Corporation 





\title{
MEMOIRS
}

\author{
OF THE
}

\section{LIFE OF AGRIPPINA,}

\author{
THE
}

WIFE OE GERMANICUS. 



\title{
MEMOIRS
}

\author{
OP THE
}

\section{LIFE OF AGRIPPINA,}

THE

WIFE OF GERMANICUS.

\author{
$B Y$ \\ ELIZABETH HAMILTON, \\ AUTHOR OF " LETTERS ON THE ELEMENTARX \\ PRINGIPLES OF EDUCATION;" \&c. \&c.
}

"Hitory may be faid to embody Truth, and prove from Facts "the Reafonablenefs of Opinion." Johnow.

\section{Jonnow.}

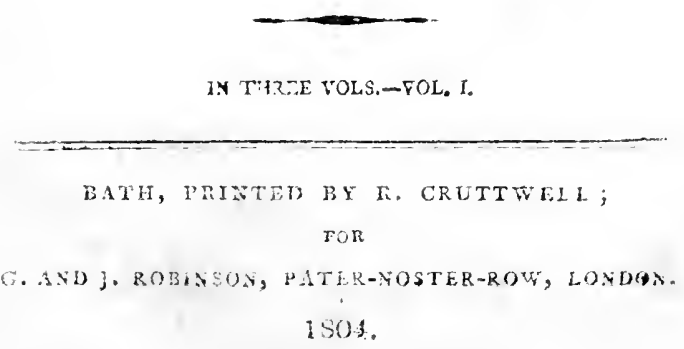





\section{CONTENTS.}

PREFACE.-P. vii.

GENEALOGICAL SKETCH.-P. xxxir.

CHAPTER I.-P. 1.

Preliminary Observations on the History and Character of the Ancient Romans.

CHAPTER II.-P. 62.

OCtavius Cesar, his Birth; Education; Marriage with Scribonis; Divorce; Marriagerith Liq1a. -Education of Junia; her Marriage with Mar. cellus; with Vipsanius Agrippa; with TibeRIUS.

\section{CHAPTER III.-P. SO.}

Agrippina's infant Charafler; Care of Avgustus in her Education; contrabled to GERMANICUs; her Mother's Profligacy and Wretchedness.

CHAP. 


\section{CHAPTER IV.P. 105.}

Conduct of lavia to AGrippixa anil ker Brotiers.-

Lucius C.esar sent from Rome-Calus Ciasar married to Lrilla ; sent into Asia.--GERMANICUS arsibines the manly Goring married to AGRIPrina.

\section{CHAPTER V.-P. 122.}

Lucius Casar sent to Marseilles; dies by Poison.Augustus made acquainted with Junn's guily Contuft; his Grief.-Trial of JuL1A; her Banistment.-Dexth of Cart S CasAR.-Recall of TIBLRius; alopted by the Emperst-Gernavicus aloptad by TIBERIUS.

CHAPTER VI.-P. 152.

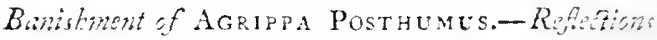
on the Condut of Augustus.-Domestic Life of Arrippina.-Domestic Ecoromy of the Rominis.Importance attacted to Education.-Slazery.-7.:-

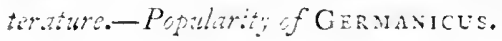

\section{CHAPTER VII.-P. 179.}

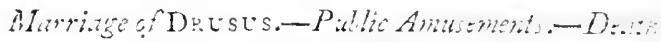

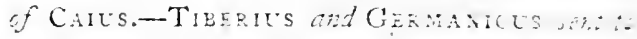

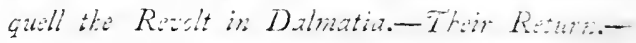

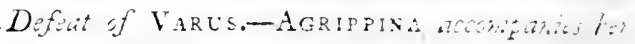

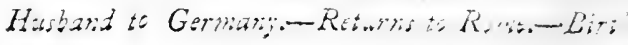


y Caligula.-Second Expedition into Germany. - Deatí of Augustus.-Murder of Agrippa Postriumus.

CHAPTER VIII.-P. 224.

Feurs of Tiberius.-Loyalty of Germanicus.Agrippiva accoinpanies bim into Gaul.-Mutiny of the Legions.-Heroism of Agrippina.-At the Request of GERManicus, she retires to Ubiorum Oppidum.

\section{CHAPTER IX.-P. 256.}

AgRipPINA proceeds to the City of Ubii.-Manners of the Germans.-Entertainments.-Martial Dance. -Gaming.-Resped for their Female Relations.$A$ German Wedding.-Thusselda the wife of Arminius.-Her Adventures. 

$7 \mathrm{O}$ point out the adrantages which 1 are to be derived from paying some attention to the nature of the human mind in the education of youth, was the object of a former work; the Author's aim in the present is to give such an illustration of the principles that were then unfolded, as may render them more extensively useful.

In the task of instructing others many are indeed concerned; but the duties of self-instruction and sil:government are imposed on all. Whorot. 1.

a

erer 


\section{[ viii]}

ever can lend assistance towards the rue performance of these important duties, may be considered as the bene. factor of the human race; and from the approbation with which her feeble efforts have been hitherto honoured, the Author is convincel, that even those who bring their single mite into the treasury, shall in no wise fail of reward.

Such a knowledge of the human mind as is to be obtained from observation and experience, appears to be placed within the reach of every one capable of reflection, and this retlection it is the aim of every moralist to excite, when he reasons upon the consequences of vice and virtue: But. io those who wish to attain a knowledge of their own licarts, and are anxiously solicitons for their improvement, something more than gencra! ohservations ase requisite. 


\section{[ ix ]}

in order to the government of the passions, it is necessary to be acquainted with their origin and progress; a species of knowledge, to be derived not so much from a riew of their consequences, as, from an accurate observation of their gradual developement. In pursuing this encuiriry, we ought not to be discouraged at finding it more complex than we at first view apprehended. The metaphysician may indeed separate the passions from each other, as the experimental pliilosopher separates the rays of light by the prism, and represent each singly to our view in one uniform colour. But in human character it is not thus that the passions are found to appear. Every passion, even that which predominates, is there seen blended with those which gave it birth. and with the passions and affections "o which it has aftinity: and it is by 


\section{$\left[\begin{array}{lll}x & ]\end{array}\right.$}

observing these affinitics, that we are enabled to pronounce on the good or evil tendency of any particular passion. If pride, for instance, be a virtuc, it will be found in connexion with, and productive of, affections of the benerolent class; if on the contrary it should appear allied to the malerolent and vindictive, we need not hesitate to pronounce it a dangerous inmate of the human bosom.

Convinced of the importance of throwing light upon a sulject so universally interetsing, and fully aware of the dislike which the young and unreflecting are apt to conceive again.st whatever appears in a diclactic form, the Author formed the design of conveying the observations that had occurred to her, through a more agreeable medium.

She soon perceived that it was not by fiction her purpose could be accomplished. 


\section{$\left[\begin{array}{ll}\mathrm{xi} & ]\end{array}\right.$}

A work of imagination, in which the characters are of the author's own creation, and in which every event is at his disposal, may be so managed, as to be admirably calculated to pro. mote the reception of a farourite theory, but can never be consiclered as a confirmation of its truth. Nor will the tineory built upon such a basis be of long duration; for though the brilliant illusions of fancy may affect the sensibilitics of the heart, and so far captivate the understanding as to render it unwilling to exert itself in detecting the fallacy of arguments which have spoken so powerfully to the feelings, the charm will at length be broken, and then the system which had been supported by its influence, will inevitably sink into disgrace.

The characters in a work of imagination may, it is true, be drawn in ract conformity to nature, and placed 


\section{[ xii ]}

in such situations as to afford a strihing illustration of certain truths; but how are those who are little accustomied to make observations on human life to judge of the genuineness of the representation? They cannot appeal to experience, and if they refer to the feelings, it is but too probable that the decision will be erroneous. Should it even be otherwise, there is still reason to doubt whether the emotions produced by the narration of fictitious events will awaken those reflections upon the progress of the passions, for which the work may have been principally intended.

Where the effect produced upon tire feelings is powerful, all that is adrlressed to the judgment appear's dull; nor is it to be expected, that the roung and ardent mind will receive much insprovement from lessons of wistom, perused at a moment; 


\section{- [ xiii $]$}

"When hope and fear alternate fway the breaft,

"Like light and fhade upon a waring field,

" Courfing each other."

If from an interesting novel so litthe is to be expected, from a novel void of interest we can hope for nothing; since, however wise, however moral, it.would have few readers. The same sermon which a person of taste would listen to with delight from the mouth of the preacher, would, if delivered from the stage, appear intolerably dull. So necessary it is that the tone of mind should be in unison with the object of attention! Hence arises the advantage which the biographer possesses over the novelist. Amusement is expected by the reader from both; but in sitting down to peruse the memoirs of a fellow-being, in whose past existence we have assurance, in whose cternal existence we have hope, the expectation of amuscment is chastened

by 


\section{[ xiv ]}

by the solemnity of the ideas attached to truth. The emotions produced will, on this account, be probably less vivid, but the interest will be deeper; while the impression made upon the mind, by a belief in the reality of the scene will give a peculiar force to whatever is calculated to operate either as warning or cxample.

Such was the tenour of the arguments which determined the Author in fafour of biography. What subject to make choice of, was the question that next occurred; and it must be confessed, that it was far from being easily resolved.

To give the memoirs of those who have but lately departed from the scene, and who still live in the hearts of their friencts and the memory of the public, may at first view appear an easy task. Concerning them there seens to be no difficulty in obtaining information. 


\section{$\left[\begin{array}{ll}x v & \end{array}\right]$}

information. All the events of their lives, their peculiar habits and sentiments, their joys and sorrows, their frailties and their rirtues, may be collected from the lips of living witnesses. Buit even with all these sources: of information at his command, the biographer who wishes to convey instruction to the living from the grave of the dead, will find himself encounpassed with many difficulties. The obstacles by which he is opposed, are, in some instances, such as sensibility will never attempt to surmount; and in others, of a nature which not even the united powers of industry and genius can overcome.

In the lives of persons who have filled a private station, exercising their talents and their virtues in the performance of the relative and social sluties, there may be much to honour, and much to applaud; but thicre can- 


\section{[ si $]$}

not, in the nature of things, le a sufficient varicty of incident to attraft. attention. In the few instances where. the memoirs of such persons have been given to the world, we accordingly seldom find more than a general eulogrium on their characters; which, tho it may leave an impression farourable to virtue, is not calculated to add much to our knowledge. Nor concerning rikrse who have been placed in situations more conspicuous, who in their hes were considered as the ornaments of their country, and whose names are mniversally known anel renerated, is it exay for the biographer to give such particulars as can alone convey a full anel just idea of the character.

To trace the progress of an extramelinary miud from the first dawn of genius to maturity; to mank the circumstances from which it receised its neculiar bent; to develope the sources whence 


\section{[ xvii ]}

whence the understanding derived its stores; and thus (if I may be allowed the expression) to pourtray the characteristic features of the soul, though a task that requires transcendent abilities for its accomplishment, is but a part of what the biographer is expected to perform.

Every individual, however high his. intellectual cndowments, is impelted by passions, and influenced by affections, which essentially affect his character and conduct. Without a compleat display of these, the delineation will remain imperfect; and yet completely to delineate them, is not in human power: for however possible it may be to trace the progress of talents, and to take the measure of the understanding, HE who made the heart can alone appreciate its frailties and its virtues. Their record is on high, but the memorial that remains is imperfect, 


\section{[ xrii ]}

fect, and the manner of their growth has eluded obscrvation. To special acts of benevolence many may indeed give testimony; but the secret trials of the heart, those exercises of patience, forbearance, and fortitude, by which it obtained a triumph over the selfish affections, are not of a nature to be disclosed.

In private life, the virtues are cxcrcised by the temper, dispositions, and sentiments of those with whom one is intimately connected. Wisdom is learned from experience; and this experience is in many instances derived from the errors of the individual, or from the errors and frailties of those most dear to him. These are, thesc ought to be, for ever reiled from vulgar eres. The heart must be without a spark of delicacy or feeling, that would roluntarily drag them into notice. 


\section{[ xix ]}

If in tracing the virtues of the illustrious dead we find it so difficult to arrive at truth, how shall we dare to dip our pencil in the darker shardes? Is it from indifferent spectators, from friends or foes, that we shall take our colouring? Upon whom, alas! can we depend? Casual observers are liable to misapprehension; where there has been enmity, there will be prejudice; and ill would it suit the tenderness of friendship to point out the blemishes which have been washed with its tears, and to harrow up the faults which time would soon have buried in oblivion!

Nor is it from what passes in conversation, when the spirits are animated beyond the usual tone, and the mind is influenced by associations which an intimate acquaintance with crery member of the company could alone: explain, that a just iccei of the princi- 


\section{$\left[\begin{array}{lll}\mathrm{x} x & \end{array}\right]$}

pies and sentiments of an individual is to be obtained. The observations which drop even from persons of deep reflection, upon subjects casually introduced, are not always to be received as conclasive testimony of their serious opinions; far less ought the expressions drawn forth by opposition in the warmth of colloquial debate to be recorded as certain indications of peevishness or irascibility. The writer who speaks from his own knowledge, may doubtless, in his statement, be exceedingly correct; he nay describe with faithful accuracy the personal defects, the incidental weaknesses of a departed friend, and by his philosophical impartiality entitle hinself to rank with the investigator of nature,

"One who could peep and botanize

"Upon his mother's grate!"

But with whaterer avidity this species of information may be recrived, we llatural!y 


\section{[ $\mathrm{xxi}]$}

aaturally revolt from the hand that offers it. It is also to be questioned. whether all that could be learned fron: such disclosures of the secret transactions of private life, would in any degree compensate for the moral crits wbich would ensue, did such instances of breach of confidence become common. Intimacy wouk then be considered as a snare, and the companion of the social board dreaded as it spy, who was to report to the world? the unguarder sallies of the moment.

Are we, then, it may be asked, to make no enquiries conceming the characters of those who have gone lefore us to the silent house: Shouki delicacy with regard to the feelings of surriving friends be permitted to silence the roice of twith : or respect for departed genius to cancel the renembrance of its follies, and to reil ins crimes?: On this general riew of the 


\section{[ xxii ]}

question it becomes not the present writer to decide. It is enough for her to point out the difficulties which must be encountered by a mind not destitute of sensibility, in attempting to give a genuine likeness of any wellknown eharacter.

If uncertainty dwell upon the transactions of a recent period, it may be deemed fruitless to carry our researches into times that are now remote: and fruitless it must undoubtedly prove, if we confine our enquiries to the lives and characters of private citizens. Eren of those votaries of science, or favourites of the muses, who have "built to themselves a name," how few are there concerning whom we can now obtain such information as would afford any addition to our knowledge of the human mind? Of such however it cannot be said, that " their memorial has perished with them." In their writings. 


\section{[ xxiii ]}

ings they ha ve left an evidence of their talcnts, whose testimony cannot be suborned; but still they do not afford sufficient data to the biographer, who is required to give an account of the actions, as well as of the sentiments. It he go, to former ages in quest of materials, he can only hope to find them in the page of history; and the transactions that are there recorded, will, in the opinion of many, appear too far removed from the occurrences of common life, to convey instruction to those who aspire not beyond the sphere in which Providence has placed them.

$\mathrm{T} \Theta$ the writer of the following memoirs the objection above stated did not appear so forcible as it has been by others represented. In order to get a clear insight into the nature of the passions, and the consequences arising from their indulgence, it is perhaps 


\section{[ xxiv ]}

necessary that we extend our view berond the station in which Providence has placed us. If human nature be our object, it is needless to confine ourselves to rank, or sex, or perion of society, for we shall find it in crery clineandsituationinfariably the sume.

The actions of a person of exalted rank nay not, it is true, afford us any directexample caprablent application to the transations of our linited ophere; but are we hence to inter, that an examination of the passions and opinions in which those attions originated, is without its lise: To know how this man mese to pwer, and that atchered greatuess, ma be a fiuitlens specularion to the mivate citizen. But to Know how far the atamment of the ofjectofiandition tendert to happines; to areertain the comsequences of indukging the lowe of walth. or power. xy distincton. and all the pasions with 


\section{[ $\operatorname{xxr}$ ]}

Which they are connected; are objects in which all have an equal degree of interest. When the sphere of action is circumscribed, the passions must of necessity be subject to controul. It is in the rank soil of unlimited power that we are to look for these giant productions of the active principle: but let it be remembered, that though situation may lop some of the most. lixuriant shoots, the root is still the same; and that human pride operates in the production of human misery as certainly in the bosom of the peasant as in that of the prince.

That the characters of those who stand on the dangerous pinnacle of greatiess are peculiarly liable to misrepresentation, cannot be denied. Their crrors are marks at which calumny delights to throw her darts, whilst flattery holds up her concave mirror to their slightest virtucs. But 
as time adrances, malice and flattery disappear; and from artions which have been scrutinized and canvassed by friends and foes, and received and acknowledged as facts by both parties, truth then endearous to extract the evidence on which posterity is to pro. nounce its verdict.

It is, indeed, the conquerors and disturbers of the carth, to whose actions the attention of succeeding ages has been chictly deroted; "for," as it has uern well observed by a renerable historian, "it has mifortunately happen-d. the Muse of Ilistory hath been so much in lofe with Mars, that she hath consersed but little with Minerva."*

the character of Agrippina must be considered as an exception to the above ubseration. By the masterly fand of lacitus it has been delineated

"Henry's Hit. ui Bridin, wal. in p. gI.

with 


\section{$\therefore$ [ xxvii ].}

with a force and spirit, which gives the original to our eyes glowing with life and animation. The features are, indeed, so prominent, that the most unskilful artist could not fail of taking a likeness; and it is this consideration which has chiefly operated as an encouragement to what has been attempted in the following pages. The age in which Agrippina lived is likewise considered as a favourable circumstance. With the names of her contemporaries all are in some degree conversant. The most remaikable erents of the period are so familiar even to the unlearned, that imagination can without difficulty enter on the scene, and be pleased to form an intimacy with objects which had hitherto been only indistinctly riewed, as from a distance.

In singling out the grand-daughter of Angustus as the subject of her first 


\section{[ sxriii ]}

attempt at biographizal sketching, the author may perhaps have been influenced by impressions made upon the mind at that period of life when the feelings are usually stronger than the judgment: but though, on mature deliberation, she perceived that the choice was not without objections, none occurred that were of sufficient force to induce her to relinguish the design.

In one whose range of infomation is, even when compared with many of her own sex, extremely limited, and who in classical learning vies not with a school-boy of the lowest form, an attempt to approach so near to classic ground, may have the appearance of presumption: but as the most enlightened are always the most liberal and candicl, she has little reason to fear being thus interpreted.

In the memoiss of $\ln$ grippina, the learned reader will not expect to find a1) 


\section{[ $\operatorname{xxix}]$}

any accession to his knowledge with regard to farts; though, when presented in a detached form, they may possibly, in some instances, give rise to reflections that did not before occur: nor will he be displeased to re-peruse even those more trifling anecdotes, which, by delighting the youthtul fancy, had served to sweeten the labours of his school-day hours. In a work intended only for the learned, these might with propriety have been onitted; but as there are many rearlers of her own sex, who are only acquainted with the outline of Roman history, crery minute circumstance which tended to render the scene familiar to the imagination, was essential to the author's plan. In this respect, advat1tage might undoubtedly have been derived from the assistance of the artist; but by the author who aspires at haring a book approved on other grounds 


\section{$[\mathrm{xxs}]$}

grounds than the merits of its artentiticus embellishments, such decorations will be rejected, as, while they do not essentially enhance the value of the work, add naterially to its price.

It now remains to gire some account of the materials that have heen emintoyal in the compilation of the following Memoirs. These have been chiefly taken from the records of antiquity; for though it was only through the medium of translation that these coukd be consulted, it appeared more adviseable thus to apply to the source, than to seek for information from the compilers of modern history.

Mr. Murphys translation of the Annals of Tacitus, and the notes prefixed to that valuable performance, have afforded almost the whole of the outline; occasionally assisted by Suctonius, in Mr. Thomsons translation. For whatever related to Agrippina in Dio Cas- 


\section{$\left[\begin{array}{ll}\text { xxxi } & 0\end{array}\right.$}

sius, or in V. Paterculus, the Author has been indebted to the kinduess of two learned friends, who obligingly translated such extracts from each as they thought would be in any wise useful. In the description of manners and customs she has been assisted by the works of numerous writers, but where accuracy was required, has chicfly consulted the treatise of Mr. Adams on Roman antiquitics. To aroid swelling the page with a parade of quotations, authorities have never been referred to, except where the very words of the author are quoted; and it is believed that those who are most intimately acquainicd with the original, will not be most forward to tax the author with having exaggerated the features of the portrait, which, with feeble hand, she has attempted to delineate. 


\section{[ sxiil ]}

In the life of Agrippina, sinc Ina never departed from her authoritics; though where they were silent, slue has endeavoured to fill the chasm in the manner that appeared most consonant to probability. The employment of Agriphinas leisure hours, her iomestic avocation', society, de. were circumstances which it suited not the thenity of history to record. Bat circumstances too tivial for history ale essentially necessary to the biographer, who ains at exciting an interest for the subject of his memoirs in the read. crs breast. General descriptions prosses not a sufficient influence os er the imagination or the feelings, to answer hiv purpose. "Where we de not coneerve distinctly, we do not sympathize cecply in any human affection.".*

If Agriplina may sonetines be foum in scenes into which she was not frol.

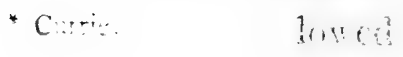




\section{[ xxxiii ]}

lowed by the historian, - the scenes themsclves, every object with which they are filed, and every onament by whin they are decorated, are faithfully copied from the most authentie describers of ancient manners.

The period of Agrippinas residence in Germany could not be passed orer without some account of the native inhabitants. In a detached form, this accomnt would have been disgusting to those to whom it was aiready familiar, and dull and uninteresting to the ignorant. By interwearing it with the merrative, it was hoped that it might be rendered acceptable to both. In a few other instances a similar liberty has been taken. How far the anthor has suecected upon these occasions in keeping up the character of the heroine, by ascribing to her such sentiments and feelings as were perfectly 


\section{[ xxwir ]}

fectly appropriate, crery rearler will for himself determine.

Throughout the whole performance criticism may find mich to censure, but it is hoped that candonir will find something to applaud: and let those who arc least willing to admit extenuation or apology for the author: failures renember, that "to have attempted much is always laudable, eren when the enterprise is above the strength that undertakes it." 
1 xxxy

\section{GENEALOGICAL SKETCII}

AS the names that moft frequently occur in thefe Memoirs are all in fome degree connected with the family of the Cæfars, in order to give a clear idea of their different degrees of confanguinity, it may be proper to prefent the reader with a thort therch of the three principal branches, and the manner in which they are interwoven with each other. Thefe are, firft, the defcendants of Auguftus; fecondly, the defcendants of Livia, adopted by Auguftus; and thirdly, the defcendants of his fitter Oetavia.

Caius Octavins Auguftus Cxfar was the son of Caius Octavius, by Atia, the neice of Julius Cæfar. He married, firft, Claudia; coond, Scribonia: and third. Livia. B!

Scribonia 


\section{[ rxxi]}

Scribonta the had one daughter, Julia, whe marrieci, firti, Mareellus; fecond, M. Vipfanius Agrippa; and third, Tiberius.

By Agrippa Julia had live children; viz. Caits, Lucius, Agrippina, Juliat, and Agrippa Pofthumus. Her focond hutband Y. Agrippa had by his fint marriage with Pomponia, the danghter of Atticus, one daughter, Vipfunic Agrippina; who wits married beft to Tiberius, the itep-fon of Anguttus, and fecondly, to Afmins Gallus. Viplunia was confequently (though no relation to Augutus) half-iffer to his grand-children.

Octavia, the fifter of $\Lambda$ uguftus, was married firft to Cladidus Marcellus, by whom the had two daughters. After the death of Marcellus, Octaria marricd Mark Antony, by whom the had two daughiers, both of the name of Antonia. Her fecond daughter by Mareelis was marricd firt to Agrippa, (mentioned abore) fecond to Julius Antonimus, the fon of Antony by his former wite.

Octaria's danghers by Antony were manied, the che re to Donitius Anobarbus; tic younger to Nero Drufus, the fou of Livia, and brothex ot'Tiberius. 


\section{[ xxrrii ]}

The children of Antonia and Drutus, wetr, frft, Germanicus; fecond, Claudius; third. Licilla. Germanicus, fon of Antonia, and rrandion of Octavia, married Agrippina, the grand-daughter of Auguftus.

The fors of Livia, the third wife of Auguftu. by her firt hathand Claudius Nero, were, thr. Theriur; fecont, Nero Drufus.

Tiberizs marred, firit, Vipfania Agrippina; wid fecon, Jelia, itepwother to Tipunia, and daughter to Anguftus.

Iy Vipfania Tiberms had one fon, Drufus, who married his coufin Livilin, the daughter of his uncle Drufus and Antonia. Tiburins was adopted by Aluguftís A. D. 4, fucculded Inim in the empire A.D. 14, and died A. D. 8.

Drufus, the fecond fon of Livia by Clatidix Nero, married Antonia, as mentioned abowe; her fon Germanicus, by his marriage with Agrippina, united the family of Liria with that of the Cxfars, and joined the two banches of the honfe of Octaritis. Their children wers related cqually to Auguftus, to Octavia, and to Livia; their names were as foliow:

1. Nero Cafä. Ite married his coufn Inlia, grand-daugher of Therins, and daughter ot Drutus and hisilld.

$\therefore$ Druits 


\section{[ xxxviii ]}

2. Drufus Cafar. Amilia Lepida became his wife.

3. Cains. Died in infancy.

4. Drufus Cafar, afterwards named Caligula. He maried, disored, and murdered fiveral wives.

5. Agrippina. Married, firf, Domitius Enobarbus, by whom the had one fon, Nero emperor of Rome; ficond, to Palsianus Crifpus; third, to her uncle Claudius.

6. Druflia. She was twice married.

7. Julia, She was likewile tuice marricá, but not in the life-tine of her muther. 


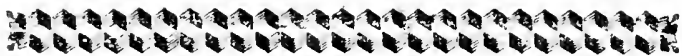

\section{CHAPTER I.}

Preliminary Observations on the History and Character of the Anitent Romans.

CO various and fo fplendid are the 1 memorials of Roman greatnefs, that had the hiftory of Rome been loft, almoft every nation of Europe and of Afia could produce fufficient tefimony of the magnificence of her views, and the extent of her conquefts. There misht have appeared to the antiquary a fatisfactory proof of the power and genius of that extratoidinary people; but records of more importance have happily been preferved, and when no veftige of Roman camp, or theatre, or temple, Mall remain, Roman literature roL. I. 


\section{$[\because]$}

will continue to excite the admiration of the world.

When we trace the progrefs of this mighty people, from an affemblage of banditti to the attainment of almoft univerfal empire; when we obferve the wifdom that infpired their councils, the fuccefs that attended their arms, and the many extraordinary proofs of heroic valour and confummate virtue which were exhibited in the conduct of individuals; we are apt to conclude, that, in mental as well as in corporeal powers, they muft have excelled the prefent race of mankind. Dazzled by the fplendour of great atchievements, we do not ftop to examine minutely into the grounds of our admiration. Charmed by the found of virtue, imagination is led captive, and we are but little inclined tos weigh the merit that has thus delighted us, in the impartial fale of truth.

So much does the colouring of the hissorian aid the impofition, that 1 believe 


\section{[ 3 ]}

few young people rife from the perufal of the Roman Hiftory with any other impreffion than that of unlimited admiration for the perfect virtue of the heroes of the republic, and of deteftation equally unqualified for their fucceffors. The mind, accuftomed to reflection, will be impreffed with fentiments of efteem and reprobation, not lefs powerful, but more difcriminating and enlightened. Taught by philofophy, and the experience of ages, to doubt the poffibility of a fudden and total change in the character of a whole people, fuch an one will not feek in recent circumftances for the caufe of taic picnomenon, but will with patient aflduity trace it to its remuteft fource.

The period of history which is cone nected with the fubject of the following memoirs, is that to which the above ob. fervation will be found particularly applicable. In the reign of Augustus, men were fuch as they had been formed by the 


\section{$[4]$}

inftitutions of the republic; and though the increating prevalence of lusury had, no doubt, a contiderable infuence in produ. cing a change in the national manners, the root of thofe more prominent virtues and vices, which ftill characterifed the Roman people, was implonted in a deeper foil.

A compleat analyfis of the caufes which operated on the formation of the national charact $r$ of the Romans, is far beyond the abilities of the prefent writen. But as the mention of a few of the more obvious may fussget fubject of reflection to thofe who would never think of looking into $x$ profound treatife, they thall be bricfyy ftate in the order they that have occurred the author's mind.

The further we extend our obfervation: upon the ditinguihing peculiarites whin form the characterific features of national character, the more fully thall we be con. vinced of the crimandinary infuence of political inftitution. Political infitution is 


\section{[ 5 b ]}

to fociety what carly education is to the individual. It gives a permanent dirention to defire and averfion, the matter-keys of all the puffions and affections of the human hart.

From minds inured to the influence of abject fear, nothing great or noble can be expected. It is a principal which necefiarily deftroys activity, and impairs benevolence, rend ring the difpofition either cruel or abject. Under tyrannical forms of government, the affociations producing fear mut inevitably have an almolt univerfal operation; individual minds may ftroggle againt its influence, hut the national character will be rendered contempible, in proportion to the extent and rigour of the defpotifm. While Rome gloried in her freedom, the contained withis her bufom an inuumerable multitude of llaves. Thefe, in procefs of time, obinitel feetom, acquired iroperty, and, from their numbers and their wealth, maty 


\section{[ $\left.6 \begin{array}{ll}6 & ]\end{array}\right]$}

be fuppcied to have had no inconfiderable influence in producing the apparent change of nutional character.

In the fince degree in which the impreffrons made by the flavif y rinciple of fear have a tendency to debale and enfecbie the human mind, will the operation of more generous motives be found to elevate and ftrengthen it. Of this nature is the love of liberty; which, when unpolluted by felfinnefs, exalts and purifies the heart. That it was, at any time, entirely free from this admixture in the Roman breaft, hiftory will not juftify us in afferting; but, limited as we munt acknowledge it to have been in its operation, a principle fo noble could not fail to produce the moft falutary confequences; nor need we hefitate to pronounce, that, from the foundation of Rome to the deftruction of the republic, the love of freedom was the foil which produced and fortered all the manly virtues.

By connecting the idea of liberty with that of the chief good, ambition was di. 


\section{[ 7 ]}

rected into fuch channels as fwelled the tide of national profperity. The love of glory, that moft active principle of the human mind, was rendered fubfervient, not to the felfin gratification of individual intereft, but to the aggrandifement of the ftate. In the mind of a Roman citizen every idea of glory was affociated with the idea of Rome: not with Rome, as the place of his birth, or the feat of his refidence, but as the community of which he formed, not a nominal, but an effential part. The ftrength of this fentiment is evident throughout the Roman hiftory; where we have many proofs, how entirely the idea of felf may be annihilated in the fervour of parriotic zeal.

This affociation, from which Rome de. rived fo much of her power and influence, may be traced to the earlieft inftitutions of the republic. By thefe it was arffully contrived, that the honour and intereft of every individual fhould be blended with 


\section{$\left[\begin{array}{lll}8 & ]\end{array}\right]$}

that of his order; while the intereft of each order was intimately connected with the intereft and prefervation of the ftate.

While the Roman people depended on pillage for their futfiftence, it was, in the fpirit of this policy, ordained, that the booty obtained in war fhould not enrich an individual, but become the property of the community. Thus, while neither arts nor commerce afforded means of acquiring property, all ranks muft neceflarily have become dependent on the public for fupport; Lur while every citizen exercifed a thare of the foverei, $n$ power, this dependence only connected the idea of individual intereit more clofely with that of the public.

A villing obedience to the laws was another confequence of this affociation; and an obedience, mingled with the love of glory, is of fo generous a nature, that it cannot fail to prove the parent of many virtues. In the carly ages of Rome, we 


\section{$\left[\begin{array}{lll}{[} & 9\end{array}\right]$}

may often obferve it giving a falutary check to pride in the moment of viftory, and affording a rallying point to defpondency after reccrit inisfortune. Thus, fortitude and felf-control became confpicuous virtues in the Roman character.

For this felf-command and obedience to the laws, the mind of a young Roman was prepared by the whole courfe of his education. The ancients were nor fo unwife as to imagine, that the paffions which have been permitted to gain an afcendancy in the infant ftate, will by rules and precepts be conjured into fubjection; they were not fo inconfiftent as to fix in the youthful mind affociations of happinefs and glory, that were incompatible with the virtues of a citizen, or inimical to the public welfare. Obedience to the laws, and to parental autherity, infend of being confidered by the Romans as adverfe to the fpirit of liberty, were damed its beft fupport; for with the Romans the 


\section{$\left[\begin{array}{ll}10 & ]\end{array}\right.$}

idea of liberty comprehended the exercife of all the duties, as well as the enjoyment of all the privileges, of a citizen. It was to this fentiment, more than to the valour of their legions, that they owed the conqueft of the world; it infpired their leaders with confidence, and breathed into their armies the foul of difcipline.

"In the times to which I now refer," fays $\mathrm{T}_{\mathrm{ACIT}} \mathrm{U}$ s, in fpeaking of the concluding period of republican virtue, "the fon of " every family was the legitimate offspring "of a virtuous mother. The infant, as "foon as born, was not configned to the " mean dwelling of a hireling nurfe, but "was reared and cherihed in the bofom " of a tender parent. To regulate all " houfehold affairs, and attend to her in" fant race, was, at that time, the glory " of" the female character. A matron, "related to the family, and diftinguifhed "by the purity of her life, was chofen "to watch the progrefs of the tender 


\section{[ 111$]$}

" mind. In her prefence not one indecent "word was uttered; nothing was done "againft propriety and good manners. " The hours of ftudy and ferious employ" ment were fettled by her direction; and " not only fo, but even the diverfions of " the children were conducted with modeft " referve and fanctity of manners. The "confequence of this regular difcipline "was, that the young mind grew up in " innocence, unftained by vice, unwarped " by irregular paffions; and under that cul. "ture received the feeds of fcience."

The advantages of this found foundation, appeared in the ftrength of the fuperftructure, and the height to which it attained. It was not the knowledge of remote facts, nor of foreign languages, nor an acquaintance with the hiftory of diftant nations, nor of any one branch of fcience or literature, that could correfpond with the Roman notions of an accomplifhed gentleman; but fuch an improvement of 


\section{[ 12 ]}

every powr and fantry, as fhould render him capdole of frrving his country in evely di fer ut capacity. The Roman canditate for pullic favour was taurnt to aet, as well as to think; and white he exercifed the active, it was not permitted him to neslect the cultivation of the faculties that are confidiced as ipeculative.

Immoral Fame, the only fpecies of immorality which beaned a fteady light upon the ligan world, was the object to which every cfiort of ambition was taught to point. The love of glory animated every exertion of the youthful mind. Infpire: by this generous fentiment, the young Ronan underwent, with patince, the fevereit duties of the military fervice; and only returned from the campaign to ren with greater ardour the ftudy of cloquence, of the laws, and of polite literature. His progrefs was not eftimated by the length of time that his name bad been enrolled on the books of an univer. 


\section{$\left[\begin{array}{lll}13 & ]\end{array}\right.$}

fity ; nor was it by keeping a certain number of terms that he obtained the ftamp of proficiency in any liberal fience. His merits were brought to a feverer teit. They underwent the fcrutiny of a jealous and difcerning public.

As there is in modern Europe nothing analogous to the conftitution of ancient Rome, young readers are apt to confider the Parician as a ftanding order of nobility, enjoying an hereditary right to the chief offices of the fiate. To corred this error, it may be neceflary to obferve, that the title of Patrician belonged only, in a proper fenfe, to thofe families of which the Senate was compoled in the eariient times, before the Commons had chtrined amimion to the public honours: bat that the character of nobility was wholly de. rived from the Curvle Magifnacies which any family had bome; and that thofe who could boaft of the greateft number were always accounted the noblert.

Thie 


\section{[ 18 is $]$}

The attainment of this illuftrious ranis was the object of a generous and nobic ambition. It was to be purchafed, through every ftep, by the vigorous exertions of manly eloquence, unblemihed reputation, and heroic virtue.

Before a young Roman prefumed to offer himfelf as a candidate for the office of Quæltor, the firft in the career of glory, he had not only fecured the favour of his general and of the army, by his conduct in a military campaign, but had given proof of his knowledge of the laws, and principles of equity, by pleading the caufe of the oppreffed before the tribunal of the public. By the conftitution of Romulus, it was made the duty, the honour, and the intereft of the rich and great, to exert their talents in the fervice of their fellowcitizens, and to become the patrons and protectors of the innocent and diftreffed. They gave their labours to the people, and the people repaid the obligation by 


\section{[ 15 ]}

the honours and preferments of which they had the fole difpofal.

That the promife of talents and of virtue, which had procured the fuffrages of the citizens to the youthful candidate, might have time for proof; five years, from the attainment of the quxeftorhip, were required to elapfe, before the offices next in order could be conferred. Thefe were the dignities of $\mathbb{E}$ dile, and of Tribune of the people.

To the former magittrate was committed the care of the public edifices, the celebration of the public games, and of all thofe fplendid ceremonies, fo dear to the populace; to the latter was entrufted a charge of more folid importance, the rights and liberties of the people. From the $\mathbb{E}$ dile was expected a tafte for magnificence, and unbounded liberality in expence: from the Tribune, all thofe qualitics neceffary to conftitute a fuccefful as well as a popular champion of public liberty. 


\section{$\left[\begin{array}{lll}16 & ]\end{array}\right.$}

IIe who had with honour fulfilled the functions of thefe fubordinate magitracies, misht, in his forty-third year, (for to that mature period did the term of probation extend) put in his claim to the office of Conful, which may be confidered as the fovereisn Aignity.

The duties of this high office required the exercife of fuch various talents, as, in the degeneracy of later times, have rarely been united in an individual. The political genius of a ftatefman, the valour of a foldier, the fkill of a general, the wifdom of a legillator, and an intimate knowledge of men and things, drawn not $\mathrm{m}$. ly from the theory of the fchools, but from the furer fource of actual obfervation. Such were the qualifications neceffary for the attainment of the confular dignity, at that glorious period in the hiftory of Rome, when her auguft fente gave laws to the world. Such were the men who, while they prefided at her councils, and led her legions 


\section{[ 17 ]}

to victory, devoted every moment that could be fnatched from the duties of an active life, to the compilation of thofe immortal works which will continue to enlighten the lateft pofterity. Thefe proofs of intellectual vigour were not confined to a few folitary inftances. They were fufficiently numerous to be characteriftic of the Roman people; whofe hifory prefents to later ages no leffon fo inftructive or im. portant, as the affurance that it gives of the confequence of beftowing cultivation, and affording employment, to all the various powers and faculties of the human foul. In the aufpicious foil of freedom the mind attains a perfection which no lefs genial influence can produce; for it is only in the foil of freedom that all her faculties are called forth. With the lofs of liberty the Romans foon loft all pretenfions to fuperiority in intellectual vigour. By the fecrecy of court policy, the fiphere of obfervation was narrowed; by its jeavor..

c lonfy. 


\section{$\left[\begin{array}{lll}1 & 18 & \text { ] }\end{array}\right.$}

loufy, the exercife of judgment was re ftrained. Tyranny prefcribed bounds to the operation of reafon; and though the germs of tafte and fancy were gracioufly permitted to expand, the fhortnefs of the period in which they fourified is a convincing proof, that where the primary facultics are without firength, thefe will foon decay.

Ii enumerating the raures which contributed to the vigour and elevation of the Ruman charaiter, we muft not cmit to mention the influence of female manners as one of the moft important. Had the minds of the Romar youth received their fint imprefions from innorance and folly, we may with fome conficnce pronounce, that the robic worid not have produced many c sampes of manly virtue. in the

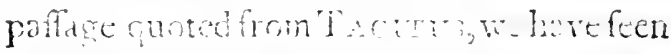
the mane in which the Roman ladies performer ane of the mot effential duties of the matron character. Taught to place 


\section{[ 19 ]}

her glory in the faithful difcharge of the domeftic and maternal duties, a Roman matron imperceptibly acquired an elevation of fentiment, a dignity of manners, which rendered her equally the object of eftcem and of refpect. Her country was no lefs dear to her than to her hutb ind; but the fame fpirit of patriotifm which impelled lim to exert his valour in the fiell, or his wifdom in the fenate, animated her mind in the inftruction of her children, and the regulation of her family. Superior to every puerile purfuit, the only object of her ambition was an increafe of the fame and glory of her race. The flrength of mind infpired by this principle does not accord with our ideas of female amiability; but when we recollect that the views of a $R O$. man matron extended not beyond the prefent fcene, we fhall rather applard than condemn the heroifm which tanght her to imprefs upon the minds of her fons, that it was better to die wihl glory, than to live without renown. 


\section{$\left[\begin{array}{lll}2 & 20 & ]\end{array}\right]$}

While the matrons of ancient Rone preferved this elevation of fentiment, they were no lefs remarkable for modefty and decorum. They had wifdom to know their proper fphere, and were not impelled by vanity to quit it. Bur though they did not think it neceffary to roam abroad in quelt of admiration, it does not appear that their infuence on public manners was the lefs falutary or exienfive. Never, indeed, does the female character appear to have been more efteemed or venerated: the refpect in which it was held, by foft. ening all the ftemer paffions, facilitated the prozrefs of civilization, and gave to the Roman mind, pcihaps, as great a degres of polifh as is confintent with any degree of Atrength.

Were we to confine our view of the rendency of the koman infitutions to their infuence upon the inteliectual powers, we huvid behold perpetual fubject of admiration and applaufe; but when wC talic 


\section{$\left[\begin{array}{ll}1 & 21\end{array}\right]$}

take a wider furvey of this interefting fubject, and obferve the manner in which they operated upon the paffions of the heart, our admiration will, in many inftances, be changed into abhorrence, and our applaufe into contempt.

Some inveftigation of this point becomes neceffary, fince without it that apparent change in the Roman character which produced the lofs of liberty, will appear violent and inexplicable. Nor is it a fpeculation of idle curiofity, but of univerfal intereft; for, were the abilities of the writer equal to the tafk, the refult would imprefs conviction on every ferious mind, that where an improper bias is given to the affections of the heart, the faculties of the undertanding, even in their moft perfect ftate, will oppofe a feeble barrier to corruption. The Romans might, on a fuperficial view, feem to have been fenfible of this, from the pains they took to guard the infant mind from the early do. 


\section{[ 22 ]}

minion of the felfin paffions; but to this they were led from motives lefs comprehenfive and enlightened. It was not from a confideration of their malignity, but of the ohftruction which they gave to the cultivation of the mental powers, that they were put under the reftraint of rigid difcipline. The $R$ omans went as far as human wifdom could penetrate; but they reached not the receffes of the heart. They endeavoured to put a falutary check upon the career of the youthful pafions, but they thought not of purifying the fource from which they fprung. The affociations, which all their inftitutions, religious and political, tended to froduce, were alliet to prite, and adverie to malevolence. The Love of Liberty, that generous principle, which, when founded on a proper bafis, embraces in its operation all the beft affections of the human heart, excited in the Roman brean an influence that was very partial and imperfect. A citizen of

Rome 


\section{[ $\left.\begin{array}{lll}23 & 3\end{array}\right]$}

Rome gloried in freedom as his birthright. He confidered his privileges as indefeafible, ineftimable, and far more precious than life: he, therefore, freely ventured life for their fupport, and entertained a jealous apprehenfion of whatever threatcned even remotely to affect them. The rights of his fellow-citizens were bis, and for that reafon were watched with the fame afidinity, and guarded with the fame vigilance, as his own; but while the confcioufnefs of freedom nerved his mind, and gave ftrength and firmnefs to every faculiy of the foul, it did not teach his heart to refpect the feelings of others; nor did it warm it with the generous wih of extending the valued blefing. With his idea of liberty the power of exercifing unlimited tyranny over a great part of his fpecies was firmly united. This fentiment, which flowed from the right that Rome haughtily aflumed of bringing all other nations into subjection, increafed with the fuccefs of 


\section{[ 24 ]}

her arms, till the fpirit of national arro. gance was confidercd as a national virtue. Nor was the pride of power confined to the body politic; it was felt and exercifed by all the fuperior orders in their individual capacity. Domeftic tyranny was authorifed and eftablinhed by the laws. The life of the flave was at the difpofal of his mafter; and by the laws of Rome, children were, in every refpect, the flaves of the parent.

Before the conquets of the Romans had introduced the more depraved manners of the Eaftern nations, the domentic flaves had all fome ufeful employment, which it was the bufnefs of the miftrefs to infpect. As luxury increafed the numbers of the menial crew, they became idle and vicious; and where the heads of the family partook of the fame character, found obfequioufnefs and flattery a furer road to favour than integrity and diligence. The moral conduct of thefe defpifed beings feems 


\section{$\left[\begin{array}{ll}25 & 25\end{array}\right]$}

feems, indeed, to have been little more the object of attention to the Romans in their Pagan ftace, than it has been in after times to fome of thofe who call themfelves Chriftians. Not that the Pagans were univerfally infenfible to the moral improvement of their flaves; in moft families of any note, the education of thofe of tender years was an object of peculiar intereft, and many of the flaves of both fexes were inftructed not only in the arts which contribute to luxury, but in the fciences which ornament it.

Nor was Hope, the beft comfort of our imperfect condition, denied to the Roman flaves. Under a generous matter, emancipation was almoft the certain reward of good behaviour; thofe who could render themfelves in any way ufeful, feldom failed, in the courfe of a few years' fervitude, to obtain the fame favour. Nor were they even in their ftate of bondage deprived of all poffibility of acquiring property; 


\section{$\left[\begin{array}{ll}26 & \end{array}\right]$}

they were frequently fo rich as to be ena. bled to purchafe their liberty; but even after thcy hid obtained freedom, they were ftill confudered as belonging to the family of their laft owner, who, in having exchanged the rights of proprictor for that of patron, had bound them by a frronger, becaufe more natural tie. The number of freed-men and frced-women attached to every fanily of dillinction was immenfe; fome of thefe, by exerting their talents in the arts or in commerce, but many more by the lefs honourable means of fraud, flattery, and peculation, attaned the poffeflion of enormous wealth. The conftant fociety of minds embued fo deeply with the felfith principle could not fail of being prejudicial to the young, and may doubtlefs be afcribed as one of the caufes which accelerated the progrefs of corruption. Whatever may be averred of the flave fyltem in modern times, it is very cvident that its effects upon the Roman mind were excealingly 


\section{[ 28 ]}

exceedingly pernicious. As flaves were not confidercd in the light of rational beings, their evidence was not admiffible, unlefs when it was extorted by torture. It appears to have been a point of honour to make offer of the fufferings of thofe unhappy wretches for this purpofe, whenever perfons of rank wilhed to clear themfelves from the imputation of any fate offence; and the coolnefs with which this offer was made, and the indifference with which the practice is mentioned, alike bear teftimony to the degree in which the habir of exercifing abfolute cominion over fuch a valt portion of their fellow-creatures had deAtroyed the fympathies of the human heart.

As the manners degenerated, crucliy increafed; and as the cruel had fomething to fear from the workings of revenge, the life of the manter was guarded by a law, which ordained, that if the matter was murdered by a flave, all the others, in his family, of either fex, and of every age, 


\section{$\left[\begin{array}{lll}2 & 28 & ]\end{array}\right]$}

fhould fuffer death.* That a law fo barbarous fhould ever have been deemed neceffary, is a fufficient proof of the tendency of flavery to produce and fofter the malignant paffions; and that its rigour fhould have been juftified in a period of unexampled refinement, fhews that the degrading influence of this pernicious fyftem operates upon the enflaver no lefs than upon the enflaved.

While fimplicity of manners prevailed, and poverty reftrained the licentioufnefs of free-will, the confequences of that pride, which the poffeffion of power never fails to engender, was difguifed or rendered innoxious by the refpect for public opinion.

* The number of naves at one time led to execution in the reign of NERO occafioned a popular infurrection. Many even among the fenators relented at the idea of laughtering four hundred pergons for the guilt of one; but the rigour of the law was vindicated by an able fpeaker, and all were doomed to fuffer, without diftinction of fex or age. 


\section{[ 29 ]}

It was not till it had formed a junction with avarice and fenfuality, that it was feen in its true colours, as the parent of the malevolent pafions. When this period of corruption arrived, the power of exercifing tyranny and opprefion on the wide field of a provincial government, became the prime object of ambition. It It was now that the nations which had yielded to the fuperiority of the Roman arms, firft felt the fatal confequences of fubjection. The groans of the miferable excited neither the feelings of thame, nor of compunction. Every commanuer was not a VERRES; but from the ac unts tranfmitied to us of the manner i which the proconfular authority was sercifed by fome of the moft diftinguifhed characters that graced the latter period of the republic, we may be convinced that abfolute power will feldom make to itelf very rigid rules of juftice.

If the civil infitutions of the republis had any influence in the formation of nation! 


\section{[ 30 ]}

character, that influence was incalculably increased by the power of fuperftition.

"The religion of Rome," fays Mr. Gibion, "was not merely a fpeculative doctrine, profteffed in the fchools, or taught in the temples. The innumerable deities and rites of Polytheifm were clofely interwoven with every circumftance of bufinefs or pleafure, of public or of private life; and it feemed impofitible to efcape the obfervance of them, without, at the fame time, renouncing the commerce of mankind, and amufements of fociety."

A worfhip which thus mingled with all the tranfactions of common life, could not fail to affix certain ideas of refpect, reverence, or afickion, to the charaster or uffice of the deitics, who were the oljects of fuch devout aboation. If we take the liberty of examining the "cleswit mythology" of tise Heatuons, we hall not find much reafon to imagine that thefe affocia- 


\section{[ 311 ]}

tions were very likely to improve the virtues of the heart. The fullen tyranny of Jupiter, the vindictive malice of his royal confort, the licentioufnefs of Venus, and the brutal fenfuality of Bacchus, were acknowledged characteriftics, duly celebrated by their refpective votaries, Pride, revenge, and fenfual indulgence, being thus confecrated by the example of the gods, wcre clevated to the rank of virtues.

It is obferved by the elegant Author of Decline and Fall of the Roman Empire, that " the public fpectacles were an effential part of the cheerful devotion of the Pagans, and the gods were fuppofed to accept, as the moft grateful offering, the games that the prince and people offered in honour of their peculiar feftivals." Of the public fpectacles exhibited at the games, the combat of gladiators, and the tunting of wild heatt", appear to have been at all rimes held in highe:t eftimation. In the former, men, regularly 


\section{[ 32 ]}

trained and educated for the purpofe, fought, and bled, and died upon the public ftage; the magnificence of the entertainment being in proportion to the number of the wretched victims. In the latter, a number of ferocious animals, whofe fury was augmented by every art that ingenuity could invent, were let loofe againlt a few timid and defencelefs laves, whofe Thrieks of terror and groans of agony were drowned in the louder acclamations of the rejoicing multitude!

To behold the agonizing wounds and painful deduhs of thefe unhappy mortals, might be deemed a grateful fpectacle to the gods of Rume; but one who has been educuied under the benevolent fyitem of the Gofpel, mut have fuccefsfully combated with many early prejutices, before he can allow to fich exhibit ins the appellation of chorful! Had hiftory havded down to us no wther means of afcertaining the general difpofition of the Romans, the de. 


\section{[ 33 ]}

light which they took in contemplating fuch horrid fcenes, would be fufficient evidence of its tendency to cruelty. Before the fufferings of any living creature can afford a pleafurable fenfation to the human mind, the generous fympathies of nature muft have been extinguifhed; and fo powerfully are thefe fympathies connected with the benevolent affections, that all the virtues of the heart are impaired by their annihilation. We cannot fuppofe, that he who was accuftomed to view with complacency the agonies of a fellow-creature, even though that fellow-creature was degraded to the rank of flave, would have much compunction in following the dictates of revenge. Nor need we fcruple to infer, that he who regarded the life of a flave as an object of contempt, would, when paffion prompted, and opportunity occurred, thew-little regard to the life or happinefs of a fellow-citizen.

The page of hiftory bears teftimony to the fact. We there perceive, even in the VOL. I. 


\section{[ $\left.34 \begin{array}{ll}34 & \end{array}\right]$}

ages of politenefs and refinement, the permanent effects of thofe inftitutions, which had torn from the heart the tender feelings of humanity.

The clemency of Augustus has been the theme of eulogium to authors, ancient and modern; yet Augustus, the patron of letters, the mild, the polite Augustus, * with his own hands tore out the eyes of Gallius, theprotor, after having feen him put to the torture! The only crime of the

* There are fer things more worthy the animadrefinn of the moralift, than the inproper ufe of epithets. The young reader, afraid to truft his own judgment, relies on the fuperior penetration of his au. thor. When he oberses the proptrator of actions from which his felings revelt, and which his principles ovght uneginvorily to condernn, decorated with ap. pe.tions tha ix ixlong to bencrolence and integrity; his idess of right and wrong, are in danger of being perplexal, vice becomes lefs and lefs the object of his batrut, and sirtue ceades to infire the wamth of ap. probation. Where the tite of an author cielights the imasination, $i$ is orfy, by falle epithets, to miflead the judgrent; and perbaps there is none who ourht to be

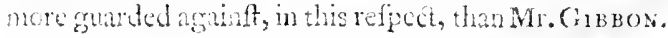

unhappy 


\section{$\left[\begin{array}{ll}35 & ]\end{array}\right.$}

unhappy nobleman was that of having excited the fufpicion of the tyrant by carrying under his cloak a double tablet, which was unfortunately miftaken for a fword!*

Augustus was bred to the trade of war, he had been practifed in the fcience of deftruction, and therefore may be confidered as an exceptionable example: but to the younger Pliny no fuch exception can be taken. Dittinguilhed by genius, enlightened by philofophy, endowed with all the endearing qualities of the heart, $P_{L I N Y}$ was with juftice confidered as the moft accomplifhed nobleman of his times. When

* Suetonius, p. irl. Thompson's Tranflation. Let the behariour of AUgustus upen this occafion be compared with that of a Chriftian wonarch, when his life was actually endiangered $b-$ the bail of at minin, and our blind admiration of ancient feritue. and ancient clemency willabate fomewhat of its fervour. IId the unhappy maniac, who ained the fatai blow at our beloved fovereign, lived under the mild acminitration of Augustus, it is more than probable l'int his wife, and family, and friends, would have been deroted to torture and to death! 


\section{[ 36 ]}

fuch a man as Pliny gives an account of his having put innocent females to the torture, by way of experiment; we may juftly infer that thofe affociations, which circumfcribed the operations of fympathy, and threw contempt on the fufferings of the wretched, had a very extenfive influence.

Though in Rome the priefthood did not form a diftinet and feparate order of citizens, the power attached to the office was fo great, as to enable the patricians to maintain a decided fuperiority over the other branches of the community. Their policy taught them to increale and preferve that tendency to fupertition, which is the concomitant of credulity and ignorance. Enlifting all the friking phenomena of nature into their fervice, they made every change in the ftate of the elements, every movement of the feathered tribes, nay even the very garbage from which the eyes of delicacy turns abhorrent, 


\section{$\left[\begin{array}{lll}3 & 37 & \end{array}\right]$}

means of working on the hopes and fears of the deluded multitude.

Whoever confiders the confequences that mult inevitably arife from the habit of contantly viewing oljects as connected, that have in reality no co.nncetion, will eafily perceive, why it fhould prove almoft impoffible for the mind of man to remain uninfucnced by the prejudices which he imputes upon others. The Ruman Pontiffs, like thofe, who in times lefs remote have endeavuured to govern the vulgar by fimlar expedients, were feldom fully contcious of the fallacy and impofition of the arts they practifed. Nor let us impute to them the honour or the infamy of creating a refined fyitem of fraud, formed exactly to fuic their purpofe. The wifdom of Numa adapted the popular fuperftition to the purpofes of government; but the impreffion made upon the mind of the magitrate by omens and prodigies was not lefs vivid nor fincere than that 


\section{$\left[\begin{array}{ll}38 & \end{array}\right]$}

that which was felt by the meaneft plebeian. Accuftomed from his earlieft years to attach undefinet ideas of evil to certain phenomena, he, with unfeigned zeal, endeavoured to propitiate thofe gods, whofe capricious favour was, as he believed, to be purchared by a punctual obforvance of vain rites and trifling ceremonies. We may be affured that thefe affociations tcok too firm a hold of the Roman mind to be broken by the cobweb deductions of philofophy.

That " the various modes of workhip which prevailed in the Roman world, were all confidered by the people as equally true; by the phitofopher as equally falfe; and by the magiftrate as equally ufeful;"; is an obfervation very elegantly expreffed, but which is in fome degrce refuted by every page of Roman hiftory.

Let us refer to thofe illuftrious authors, whefe ftation on the theatre of public

* GibBon.

life 


\section{[ 39 ]}

life was no lefs eminent than that which they have continued to maintain in the republic of letters. Not to mention the writers who flourifhed in the earlier ages, let us confine our inveftigation to the works of Tacitus, Cicero, or Pliny; in all we fhall find indubitable traces of a credulity with regard to fupernatural events, omens, prodigies, and dreams, that would difgrace the moft paltry fcribbler in any country of modern Europe. That fpecies of fuperftition, which, fince the reception of Chriftianity, has only been found in connection with extreme ignorance, was among the Romans common to all. Neither genius nor learning efcuped its influence; and if on minds fo culcivated and capacious as thofe we have above referred to, the impreflion made by early education proved too powerful to be eradicated; we may affuredly infer, that a tendency to fuperftition formed a ftriking trait in the national character. 


\section{[ 40 l $]$}

As it was not pretended that the Gods of Rome were deferving of efteem, refpect, or veneration, on account of any inherent virtues; their partiality for the favoured city formed their greateft or rather their only merit. When the gods of other nations thewed any fymptoms of the fame favourable difpufition, they were received and adopted as oljicts of adoration, without any hefitation on account of their jarring attributes; and thus, in procets of time, every debafing paffion of the human breat found a patron in the pantheon of diviniries. Actuated in this particular by the fame principles of policy which induced them gradually to admit the cuics of Italy into a participation of the rights of Ro. mans, they hoped, by extending the privileges of $g$ gdfip, to increafe the number of thofe who were interefted in the prefervation of the Atate.*

* "On lçait gute les Romains a curent dans leur ville tes dieux des autres pays. Ils les recurent en conquer. 


\section{$\left[\begin{array}{ll}41 & {[}\end{array}\right.$}

The freedom of Rome was no fooner conferred upon forcign deities, than they became legitimate objedts of Roman worfhip; but we have every reifon to believe, that till tiscy were thus naturalized they were obrioxious to hatred and contempt.

"The fuperftition of the people was not," it is true, "cmbittered by any mixture of theological rancour, nor wat it confined by the chains of any fpeculative fyltem;"* but fuperflition which taught pride to gl. ry in fubduing the enmity of oppofing deities, by the invincille force of the Roman arms, cannor be fuppofed to

ans; ils les faufoient porter dans les triomphes: mais lorque les étrungers viatnt cux-même lcs etablir on les reprina d'arbord. On fçait de plıs, que les Romains avoient coutume de donner aux diritités etrangérs les noms de celles des leur qui y avoient le plus de rapport. Mais lorfune les pretres des autres pays roulerant faire adopter a Rone leur divinités tous leur propres noms, is ne furent pas toufferts; et ce fut un des grands ubticles que trouve la religion Chrétienne." -Moxtescueu fur les caules de la grandeur des Romains et de leur decadence: c. xvi.

* Gibbox. atlied 


\section{[ 42 ]}

the Roman arms, cannot be fuppofed to have been nearly allied to the "mild fpirit of toleration." Pride is in its nature intolerant and vindictive; and when we confider, that pride was in the Roman breaft combined with every idea of dignity and glory; that it was nurtured by public fentiment, and unchecked by religious principle; we thall not be very eafily perfuaded that Roman pride was divefted of any of its conftituent properties.

Such was the arrogance of the Roman fpirit, that it in many inftances perverted the judgment, and detcrred the mind from entering on the examination of objects, which true philofophy would have deemed at leaft curious, if not important. The contempt in which they held all the reft of the world, impreffed the minds even of the moft Jearned with a haughty difdain of all that was not Roman. A glaring proof of this may be feen in the account given by Tacitus of the Jewifh nation. At the 


\section{[ 443 ]}

time he wrote, the Jews had been for nearly two centuries under the Roman yoke. The conquet of Jerufalem was confidered by him as one of the moft glorious atchievements which diftinguifhed the reign of his favourite Emperor, and is defcribed with all the force and brilliancy of his incomparable pen. But though Josephus was his cotemporary, and the patron of Josephus was his friend; though Rome then was full of Jews of all ranks and defcriptions, among whom were perhaps many who did not yield to TAcitus himfelf in point of learning; the fon-in-law of Agricola diftained to feek for information from barbarians, and rather chofe to expofe his ignoranceto the latelt pofterity, than to condefcend to acquaint himfelf with the truth. When we reflect, that it was to this pride that Chriftianity had to oppofe itfelf, we fhall not be furprifed at the declaration of the Apoftle, that "not 


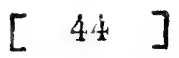

many wife, not many learned" were numbered with her early votaries.

The religion of the Pagans, as interwoven with the political inftitutions of Rome, had not only a tendency to corrupt the heart by the introduction of pride, cruelty, and malevolence; bur to feduce the ima ination, by a falle tafte for finery and thew. As a nation of warriors, the Roinan difdained all employment but that of war. Neither arts nor commerce were purfued as the means of acquiring property, and confequently the intervals of peace were fpent in idlenefs. Active minds can never be idle with impunity; and the wifdom of the legillatur faw that, to prevent mifchief, it was neceffary to furnilh the idle wirls a conftant fupply of amufement. Hence all the pomp and fplendour of the Pagan worthip; which in fo far obtained the end propofed, as it attracted the attention of the populace, and gave an object on which the reftlefsnefs of activity might 


\section{[ 45 ]}

might fpend itfelf, without diflurbing the public tranquillity. The farther confequences of a paffion for anufernent thus infpired will be feen hereafter.

Of the influence of the fenciments of honourable ambition, which were ming!ed with every endearment of maternal love, enough his already been faid, to give fome idea of the confequences that arife to fociety from the formation of the female mind. It was the union of elevated fentiment with modefty and referve, which rendered the character of a Roman matrun an object of efteem and veneration. We may however obferve, thit had the efteem which the virtues of the Roman females were caiculated to infpire, been permitted to mingle with tile paffions of the youthful bofom, the effects produced would have been fill happier and more extenive. But the chaftened fentiment of virturus love was unknown to the Roman breaft. Marriage was with them merely an infi- 


\section{[ 46 ]}

ftitution of policy. Unions were formed and diffolved from motives of intereft or convenience; but that refined affection which binds heart to heart, had no concern in lighting the hymeneal torch.

As the Romans inarried without love, we need not be furprifed to find that they loved without delicacy. Where no fentiments of efteem blend their mild influences with paffion, unbridled licentioufnefs will fooner or later be the confequence. Poverty and an active life preferved the more ancient republicans from the groffnefs of depravity; but no fooner had luxury opened the flood-gates of fenfuality, than the Romans funk into brutality. The Roman females foon caught the contagion of licentioufnefs. Unfpotted chaftity was no longer the matron's glory, or the maiden's pride. The care and inftruction of her children, or fkill and prodence evinced in the management of domeltic affairs, no longer conferred dignity in the eyes of an 


\section{$\left[\begin{array}{lll}4 & 47 & \end{array}\right]$}

ithufrious dame. The refped given to virtue could no longer gratify her ambition, for with objects of a very different nature ambition was now affociated. So that the was diftinguifhed, it was of little confequence that the was defpired. We need not feek a furer criterion of corruption.

Before the reign of Augustus, the Roman character had undergone a rapid and important change. With the influx of wealth, and extent of dominion, thole pallions whofe feeds had been fown by the religious and political inftitutions of the republic, at a period coeval with its date, ripened to maturity. Poverty and the Atrictnefs of rigid difcipline had repreffed their growth; but beneath the foftering hand of luxury, they frung and flourilhed. Every circumftance that had tended to counteract or reftrain their influence, was diminithed or annililated, before the Roman worki ftooped to acknowledge the authority of a matter. 


\section{[ 48 ]}

The important confequences of thofe hal its of thinking which blended the idea of perfonal glory with the welfare and glory of Rime, have already been noticed; but this fentiment depended too much upon fympathy, to operate for any length of time upon diffarit armies, which no longer breathed the fpirit of freemen and citiz:ns, having an equal intereft in the profperity of the commonwealth for which they fought. Compofed of va. rious nations, having no tie but that of difcipline and obedience to the fame general, they imperceptihly transferred to their commander the allegiance and affection which in former times had been referved for the ftate. The general on his part, having hal his am?ition polluted by the love of power and riches, no longer confidered the applaufe of his fellow-citizens, and the glory of an illufrious name, as rewards fufficiently folid. Avarice was the concomitant of luxury, and inordinate wealth 


\section{[ 499 ]}

wealth couid alone gratify the pride that was united with fenfuality. The command of an army, which conferred fovereign authority in a diftant province, was confidered as the fureft and fhorteft road to fortune: and as neither juftice nor compaffion to barbarians formed any part of his religious code, he omitted no methods of extortion, of rapine, or of cruelty, which could facilitate the attainment of his object. Enriched by plunder, he returned to Rome, certain of purchafing from the cupidity of a degenerate people thofe public honours which had formerly been the meed of confpicuous valour or diftinguifhed virtue.

In the tafte for thews and public fnectacles, a tafte which policy had herihed as the means of foftening the ferocity of a fierce and warlike feon: he fond a ready inftrument of cor: won. That greedinefs of amufement, whin is etcur the prognoftic or ite iynptom of the mind's difeafe, VOL. I. 


\section{[ 50 ]}

was now augmented by indulgence into an epidemic phrenzy. All the nobler affections yielded to its influence; and as the fpectacles, by which the infatiable thirft for amufement could only now be gratified, were little calculated to excite generous emotions; public fpirit was neither kept alive by fympathy, nor rekindled by emulation. In lofing public fpirit, the Romans loft the fole animating principle on which their virtues depended for exiftence. While the love of virtue was fupported by a rigid fimplicity of manners, the talents of CresAR, feconded by the wealth of Crassus, and the power of PomPEY, would have in vain attempted to overthrow the confitution of their country; but the change of manners, and the prevalence of vice, rendered it an eafy enterprife. - The penetration of CESAR difcovered the vulnerable part. Heknew that luxury is prodigal, and that prodigality is felfin, and that felfinnefs fcruples 


\section{[ 51 l $]$}

not to purchafe the low gratifications of depraved appetite at the expence of the public good. He therefore, by his example of profufion, increafed prodigality, encouraged luxury, and promoted that defire of felfilh gratification, which he knew how to turn to his own advantage.

Judging that the man who has not courage to combat his own vicious inclinations, will not evince much conftancy in the caufe of freedom; he confidered all in whom the fpirit of independence was too feeble to reftrain the love of pleafure, as deferters from the ftandard of liberty.

His expectation was juftified by the event. His camp became the afylum of every diftinguifhed profligate, who in fcenes of giddy riot or oftentatious luxury had fquandered the fortunes of his anceftors. The number was formidable. By the levity of idlenefs, and the factious fpirit of difcontent, it was every day increafed. The fortunes of $\mathrm{C}$ 促AR prevailed. But in 


\section{[ 52 ]}

fact the triumph of CESAR was nothing more than the triumph of the felfin and fenfual paftions over thofe reftraints which a contempt of riches and love of national glory had once impofed. Roman liberty did not die a violent, but a natural death. In vain did a few vigorous and independent minds endeavour to protract the hour of her diffolution. In vain did they hope from the death of C.sSAR a reftoration of her exiftence. The dagger of Brutas, might, like the Galvanic Shock, produce a Short and convulfive motion, but the animating foul of liberty, had fled for ever!

The defign of the prefent differtation does not permit us to purfue the confequences of thofe circumftances which confpired in the formation and developement of Roman character, beyond the firft ages of the empire. To the general ftate of fociety in that period we muft confine our views. But connected as that period is with an event of univerfal importance to 


\section{[ 53 l $]$}

the human race, my readers will pardon a lhort digreflion upon a fubject of fuch general intereft.

The more ferioufly we contemplate the effects of thofe affociations which the political inftitutions and idolatrous worhip of ancient Rome infpired, and which philofophy itfelf tended to rivet in the human mind; the more deeply fhall we be impreffed with admiration at the unfearchable wifdom and omnipotent power of that BeIng, by whom it was decreed, that at this very era of depravity a religion thould make its way into the world, which not only overturned the fpeculative opinions that influenced the underftanding, but compelled its votaries to make a facrifice of all the paffions and prejudices which education and habit had entwined with every fibre of the heart! Opinions which arc formed from abtract fpeculations vary with erery change in the roint of riew from which they are contcmlated; but 


\section{[ 54 S $]$}

the affociations which have engendered pride, the love of power or of glory, a difpofition to cruelty, to fenfuality, or revenge, take too firm a hold upon the mind to be diffolved at the command of reafon. The wifdom of philofophy, fo far from aiming at the fubjugation of all the malignant pafions, only partially difapproved them; each fect pleading for the indulgence of the particular clafs which was connected with its peculiar tenets. The ftern virtue of the Stoic was proud, vindictive, and unrelenting. The felfin fytem of the Epicurean was effeminate and fenfual: and although the Academic philofophy admitted of more fublime and elevated fentiments of moral duty, the foundation upon which thefe fentiments were built, was of a nature fo unfteady and fluctuating, that lowever they might occafionally influence the condust of an individual, they could have no general operation upon human character.

Completely 


\section{$\lfloor 55\rfloor$}

Completely to change the ideas of happinefs or glory in the mind of an individual, is a talk fo difficult as to have been rarely accomplifhed. To eradicate the paffions and prejudices connected with thefe affociations, may well by human wifdom be deemed impoffible, for never by human power has it been effected. To what caufe but to the overruling providence of the great $\mathrm{CREATOR}_{\mathrm{R}}$, can we then aflign the progrefs of a religion, which changed every principle of action, oppofed all the prejudices of education, and condemned the cuftoms and habits which time, and the intercourfes of fociety, had rendered congenial to the mind? In vain might PAUl have planted or A pollos watered, nothing but Divine grace could have been effectual " in turning the hearts of the difobedient to the wifdom of the juft!" But however powerfully Divine grace was maniferted in preparing the hearts of men for the reception of the $\mathrm{Gofpel}$, we have no reafon 


\section{[ 56 ]}

reafon to believe, that it at once conquered all the prejudices of education, or entirely and miraculoufly fubdued the paffions which the corrupt cutoms of fociety had inflamed and cherithed. Saint Paul, in his Epifte to the Romans, evidently addreffes himfelf to men who were ftill labouring under theinfluence of thofe affociations, whofe pernicious tendency we have been endeavouring to explain. The pain and difficulty of diffolving them could only be compared to deatb_-" a death unto fin, and new birth unto righteoufnefs." And when we confider the extraordinary change that was to be produced, we thall nor think the metaphor overntrained.

At a period when the groffent impurities were practifed without fhame and without difgrace, the Chritians were required to preferve unfpotted holinefs. Pure as the unbleminhed facrifice which they had been taught to ofler to their divinitics, they were to prefent their bodies to the LORD.

They 


\section{[ 57 ]}

They who had been acccuftomed io confider themfelves as fuperior to the reft of the human race, were no longer to think of themficlves more bighly than they ought to tbink, but to tbink foberly. The refined policy of Augus'rus had introduced that politenefs which throws the veil of deceit over rancour and internal hatred; but the Chriftians were to love without diffmulation, openly and without difguife, to abbor evil, and to cleave to that which was good. They who had had their hearts fhut againf the tender impulfes of humanity, who had confidered the fufferings of their inferiors as beneath their notice or regard, were to diftribute to the neceffrties of the faints, to rejoice with them that rejoiced, and wecp with them that weepd; and they who had been accuitomed to view revenge in the light of an heroic virtue, were to avenge themfelves no more; to give place to wrath; to feed the encmy that bungered, and to sive drink to the thirfly foe. 


\section{[ 558 ]}

Of the difficulty of effecting fuch a total change in the fentiments, manners, and affections, we who have been brought up under the influence of the Gofpel difpenfation can form but a very inadequate idea. Even the infidel who now denies the truth of Divine revelation, has drawn from the fource which he affects to defpife, ideas of moral purity and perfection which never entered into the heart of heathen moralist to conceive; vices, which, in the ages of Roman refinement, philofophers could applaud, and poets celebrate, would now procure irrevocable and difgraceful banilhment from fociety. But in the age of Nero, when the light of the Gorpel began to dawn upon the Pagan world, the heart was not only corrupted by the prevalence of vice, but the underftanding darkened by falfe notions of virtue. No wonder, then, if paffions and prejudices, which had been the growth of ages, hould fometimes appear to have retained an in-

fluence 


\section{[ $\quad 59$ ]}

Huence in the minds of individuals, however oppofite to the tenets of that religion which they now profefled.

It has been obferved by a learned prelate, to whom his contemporaries and pofterity will admit the juftice of applying the eulogium beftowed by Mr. Gibbon on thofe philofophers "whofe names adorn the age in which they lived, and exalt the dignity of human nature," that " the fame intolerant fyltem which had been adopted by the em. perors in their treatment of Chriftians whilt they themfelves were Pagans, was afterwards obferved by them in their treatment of Pagans when they themfelves became Chriftians."**

Nor is it intolerance only that defcended from the ancient inftitutions of Rome to defile the pure current of the Gofpel virtues. The long-cherifhed fpirit of Roman pride, and that love of power which was the

- The Bifhop of Landaff's Letters to Mr. Gibion. diftinguifhing 


\section{[ 60 ]}

diftinguifhing characteriftic of Roman ambition, may in after ages have been forme simes found to triumph over the meeknefs and moderation inculcated by the religion of Jesus. The impoing pageantries of Pagan worhip was another and a fruitful fource of corruption. Minds long accuftomed to attach ideas of refpect and veneration to the fplendour of decoration, the pomp of proceffions, and the obfervance of a multitude of trifling ceremonies, could not eafily break thefe affociations, however oppofite they might be to the fpirituality of Chriftian devotion. Superfition, whofe roots had taken hold of the foil by a thoufandramifications, was tco deeply fixed to be eafily eradicated. Before the firft preachers of the Gofpel it had indeed fallen proftrate; but in imperfect profelytes it revived and flourifhed; nor has it, in the centuries that have fucceeded, given way, fo as to promife its fpeedy extirpation from the Chriftian world.

Imperfecty 


\section{[ 61 l $]$}

limperfectly as the religion of Jesus may have been underftood and practifed by many of its votaries, the benevolent mind will rejoice in tracing its benignant influence in humanizing the paffions, and ameliorating the condition of the human race. Let us cherith the delightful hope, that its more perfect acceptance and more univerfal influence will complete the triumph of reafon and virtue, teaching every heart to give glory to GoD, and to glow with benevolence towards man. 


\section{CHAPTER II.}

Octavius Casar, his birth; education: marriage with SCRIBONIA; divorce; marriage with LIVIA.-Education of JULIA; her marriage with MA R CELLUS; with Vespasian US AgR IPPA; rithTrBERIUS.

FROM THE 671ST TO THE 742D YEAR OF ROME.

CTAVIUS C.ESAR, afterwards honoured by the title of AUGUSTUS, was defcended from an equeftrian family, of which his father Caivs was the firt who obtained the fenatorian dignity. His mother Atia, niece to Julius Ciesar, was a woman of excmplary conduct and diftinguifhed accomplifhments. Her care 


\section{[ 63 ]}

in the education of her fon is celebrated by TAcitus, who attributes the early maturity of his talents to her affiduous cultivation. At twelve years of age he did honour to his inftructrefs, by the elegance and propriety with which he pronounced a funeral oration in honour of her mother Julia.

But whatever applaufe may be due to the mother of Augustus for the pains the beftowed on the improvement of his mind, it is but too probable that the $\mathrm{cm}$. bued it with that fpirit of ambition which proved the governing principle of his future life. To the love of powcr all the other paffions of the heart were rendered fubfervient. Neither anger nor refentment, neither love, nor pity, nor gratitude, nor honour, were permitted to oppofe the call of intereft, or to ftand in the way of the gratification of ambition. At eighteen years of age the pupil of ATra was the moft accomplifhed of hypocrites. 


\section{[ $\left.64 \begin{array}{ll} & 64\end{array}\right]$}

Mafter of the arts of diffimulation, OcTAvius, at this early period, rendered the wifdom of Cicero, the profligacy of ANTHONy, and the levity of LEPIDUS, alike inftrumental to the accomplifhment of his defigns. Alternately uniting himfelf to the party that could beft promote his intereft, and facrificing without remorfe the friends who had fupported him, when they could no longer ferve the purpofes of his ambition; he at length, through treachery and flaughter, waded to that pre-eminent fituation, from which his uncle had been hurled by the weak vengeance of an ill-concerted confpiracy. In the refentment againf Jusius, the cool and crafty Augustus faw the effects of wounded pride, which though it could fubmit to flavery, could not brook contempt. He, therefore, took care to avoid the rock which had proved fatal to his predeceffor. Contenting himfelf with the reality of power, he quictly left the fenate, and the people 


\section{$\left[\begin{array}{ll}65 & \text { ] }\end{array}\right.$}

people in poffeflion of its appearance. Re. nouncing the hateful title of Dictator, he, under the popular appellation of Tribune and Imperator, for upwards of fifty years maintained abfolute fovereignty over the Roman world.

Could the undifturbed poffeffion of power confer happinefs, Auguftus had been the happieft of human kind; but while he tafted of greatnefs even to fatiety, the cup of blifs was often empoifoned by domettic mifery; and he who could difpofe of king. doms at his pleafure, and command the lives and fortunes of a valt portion of the human race, was a ftranger to heartfelt fatisfaction.

According to the cuftom of the Ro. mans, he had been contracted in infancy to the daughter of a perfon of rank; bur as no engagement could ftand in the way of his ambition, be no fooner found it his intereft to form an alliance with Mark Als. thony, than he gave up all thougluts of the

$$
\text { vol. I. } F \text { daugher }
$$




\section{[ 66$]$}

daughter of Ifauricus; and at the fame time that he figned the bloody profcription, which gave the beft and nobleft of his former friends to the vengeance of his new ally, he efpoufed Claudia, the daughterin-law of the profligate triumvir.* The fame policy which formed, diffolved the inaufpicious union. But what were the motives which dictated his fucceeding choice, it is fomewhat more difficult to derermine. He was ftill but in the fpring of life when he bccame the third hufband of Scribonia, who was probably his fenior in years, and was already a mother. By this marriage he had one daughter, Julia his only child.

How long he might have continued to live with Scribonia is uncertain. He complained loully of the perverfenefs of her tenper; bu: as he did not part with her, till his pantons were inflaned by another

* See Note A. at the crdof the volume.

objeet, 


\section{[ 67 ]}

object, it is poffible that the account he gave of the irafcibility of her difpofition, might only be an excufe for the ficklenefs of his own. His daughter Julia was yet in the cradle, when Tiberius Claudius Nero, a man of learning and talents, who had obtained the dignities of pontiff and of prætor, returned from Sicily, whither he had fled after the defeat of Anthony, and with his wife and infant fon threw himfelf at the feet of the conqueror. The eyes of Livia were more eloquent than her hurband's orations. Her tears obtained the pardon, of which her charms were the price. The clemency of Auguitus was extended to the friend of Anthony, on the humiliating condition of yielding his wife, then far advanced in her pregnancy, to the arms of the emperor.

That delicacy of fentiment which would in the prefent times attach ideas of infany to fuch a cifhonourable barter, was unknown to the Romans Tiberius Ncro, retores? 


\section{[ 68 r $]$}

reftored to his rank, continued to live in eftimation; and Livia was congratulated on the acceffion of dignity, without being deemed to have incurred difgrace. In a few weeks after her marriage with Auguftus, the gave a fon to her former hufband, who had her familyname of Drufus, * and who, with his brother 'Tiberius, was afterwards adopted by the emperor. No female conqueft was ever more fudden or compleat than that which Livia obtained over the heart of her imperial lover. Her power was permanent; but it was fupported by arts which truth and virtue hold in abhorrence, and employed for purpofes the moft wicked and flagitious. In cunning and diflimulation, Augreftus himfelf, the moft arcomplifhed diffembler of his times, was confefiedly her inferior. Nor did the yield to him in the itrength of her ambi-

* It was the fon of this Drufis who was married ic Agrippina. 


\section{[ 69 l $]$}

tion, or in the perfeverance with which the purfued ber deep-laid plans for the aggrandifement of her family.

Under fuch a mother it cannot be fuppofed that the tender mind of Julia would imbibe the principles of virtue. Her father, recollecting the care which Atia had beftowed on his inftruction, and from her precepts and his own experience being deeply impreffed with the importance of education, fpared no pains in the cultivation of her talents, and even feems to have watched over her morals and conduct with the moft laudable affiduity. But in vain did he endeavour by precepts to preferve the purity of her mind from contamination. In vain, by prohibiting her from converfing with ftrangers, or by or. dering a diary to be kept of all her words and actions, ${ }^{*}$ did he hope to infpire her with virtuous principles. The influence of Livia was too predominant not to extend 


\section{[ 70 ]}

to the flaves who were placed about the perfon of her ftep-duaghter; and it was not for Livia's intereft, that Julia thould be too worthy of her father's efteem.

Auguftus, difappointed in his hopes of having children by Livia, was anxious to ftrengthen his family by the marriage of Julia with his nephew, the fon of his fifter Octavia,* for whom he feems always to have preferved the tendereft affiction. Marcellus was a youth of much promife. Graceful in his perfon, engaging in his manners, and amiable in all the difpofrtions of the heart, he was endcared to the people by his virtues, and beloved by his uncle as the ornament of the Julian line. In rendering him his fon by adop. tion, and his fon-in-law by marriage, he equally confulted his own inclination and the interefts of the people. But alas! the bright profpects that opened on this

See Note B. at the end of the volume.

illuftrious 


\section{[ 71 ]}

illuftrious youth were foon clofed by deatl. His death was however glorious, for Virgil has immortalifed his memory.

The difpofal of Julia again became the object of paternal care. The perfon who appeared moft worthy in the eyes of Auguftus to fucceed the young Marcellus, was a man whofe merit might deferve the efteem of the father, but whofe manners were not very likely to engage the daugh. ter's affections. Marcus Vipfanius Agrippa, who was thus diftinguifhed by the favour of the emperor, was of low extraction, unpolifhed to a degrec of rufticity, and at this time, though not in the decline of life, confiderably advanced in years. Notwithrtanding the difadvantages of a rude exterior, Agrippa poffeffed thofe qualities which deferved the friendhip, and did honour to the difcernment, of Auguftus. The vigour of his genius fupplied the want of a liberal education. Though a ftranger to letters, he was the friend of literature; and hough 


\section{$\left[\begin{array}{lll} & 72 & \end{array}\right]$}

rhough deftitute of knowledge in the fine arts, he fo judicionly employed the tafte and prili of others, that under his direction not only R ome, but all Italy was adorned by the moit ufern and magnificent ftructures. In war he difplayed the talents of a great general, and in peace maintained a character of unblemilhed integrity. From an humble fation he had the art of rifing in the world with dignity; a certain proof that his mind was greater than his fortunes.

At the time that he was felected by Auguftus for his fon-in-law, Agrippa was enjoying the happinefs of connubial love with the fifter of the deceafed Marcellus, who had already brought him feveral child. ren. The mifery he might inflict upon his niece, by tearing from her arms the hufband of her affections, and father of her infant family, did not affect the mind of Auguitus; but to reconcile his fifter to the indignity that was thus offered to her daughter, he deigned to confider as an objeck 


\section{$\left[\begin{array}{ll}73 & ]\end{array}\right.$}

object of fome importance. Octavia had the fenfe to yield with a good grace to an evil the had it not in her power to prevent. She took home the divorced Marcella, and permitted Agrippa to purfue the path of ambition in a nearer conneetion with the imperial family.

About the fame time that Agrippa received the hand of Julia, his daughter Vipfania, the offspring of a former marriage, was united to Tiberius, (the elder fon of Livia) whofe fullen mind was foftened into tendernefs by the virtues and charms of his amiable confort.

Domeftic felicity now feemed to have taken up her abode in the family of Auguftus. Drufus Nero, the younger of his ftep-fons, whofe virtues and accomplithments were, even at an early period, the objects of univerfal admiration, was united to Antonia, the daughter of Octavia by Mark Anthony; and the ftrength that was thus given by family connexion 


\section{$\left[\begin{array}{ll}i 4 & {[}\end{array}\right]$}

to the Julian line, was augmented by the proriifing family which bleffed the union of Julia and Agrippa. Caius and Lucius, the fons of Julia, were, according to the forms of the Roman law, purchafed from their father by Auguftus, and formally adopted by him as his fons, and confequently heirs of his fortune and dignities. The two daughters, Julia and Agrippina, fhared with their brothers the tender affection of their illuftrious grandfather; who, blind to the miferies that awaited his ill-fated race, indulged the pleafing hope that his name fhould through them be perpetuated to the lateft pofterity.

The haughty Livia beheld with a jealous and malignant eye the blooming offfpring of Julia, whofe numbers feemed to prefent an infuperable bar to her ambitious views. The death of Agrippa re-infpired her hopes. While he lived, his children had a protector too vigilant to be duped by her diflimulation, and too powerful to 


\section{$\left[\begin{array}{lll}7 & 75 & ]\end{array}\right.$}

be overcome by the utmoft efforts of her malice. But when Agrippa expired, 'the defencelefs orphans came within her grafp. The compleat afcendancy which the had by this time obtained over the mind of her hufband, put them compleatly in her power; and the character of Julia was not fuch as to give her an influence that could counteract the fpecious arts of an infidious ftep-dame. After her hurband's death, Julia was delivered of her fifth child, who bore his father's nane of Agrippa, and from the circumftances of his birth, had the additional appellation of Pofthumus.

It was now that Livia took the firft ftep towards the accomplifhment of the long-cherifhed object of her ambition, the aggrandifement of her favourite fon. By her perfuafions, the emperor projected the union of Julia with Tiberius, who, though far from being inferior to his mother in ambition, was in this inftance utterly 


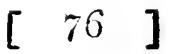

averfe from the plan which the had fo kind formed for his advancement. He luved Tinfuntat, who was now in a fituati, n tha. gratified his hopes of paternal endearment, and called forth all his tendernefs. Vipfania merited the affection of her huiband and the world's efteem, by the gentlenefs of her manners and the purity of her life. Had the continued the wife of 'Tiberius, it is more than probable, that her benignant influence would have fmoothed the ruggednefs of his nature, and chained the gloomy paffions of his foul. It was neither from her great beauty, though the was acknowledged to be beautiful, nor from the mere fiveetnefs of her manners, however captivating, that we fhould have expcted a permanent change to have been wrought in the tyrant's heart. But in addition to thefe endearing qualities, Vipfania poffeffed an elegant and cultivated mind. Her tafte for literature was hereditary; for the was 


\section{$\left[\begin{array}{ll}2 & 7\end{array}\right]$}

the great-grand-child of the celcbrated Attica, the friend of Ciccro. An attachment to fuch a woman, cemented as it was by tendernefs and teteem, could hardly fail of having a falutary influence on a young man who was neither dentitute of underftanding, nor of tafts.

In the mind of Tiberius love for fome time triumphed over amition. He refited the entreaties of his mother, and the commands of Auguftus. But the former knew how ard when to ankil him with her argunents; of in wound hira by her refenment. Mintrefs of all the averizes to his heart, the alternately pigacd his pride, and fired his ambition; till at length the extorted from him an nngracious confent to her wifines. Ite divorced the beloved Vipfania, and with ill-conceated averfron, took the widow of her father to his reluctant bofom.

The conlequences of this ill-omened union were fuch as might hawe been expected. 


\section{$\left[\begin{array}{ll}78 & ]\end{array}\right.$}

pected. Julia, whofe criminal levity had been reftrained by her refpect for Agrippa, fenfible that the was odious to Tiberius, who was probably not lefs fo to her, gave a loofe to the vicious inclinations that revelled in her heart. As her children were the care of her father, the felt not the maternal tie as any check upon her moral conduct. Her flagitious amours, though they were for fome time managed with a degree of fecrecy, did not efcape the knowledge of her hufband; who defpifed, as much as he detefted her. But it was dangerous to complain of the daughter of Augutus; and after the farrifice of his feelings which Tiberius had already made, he thought it folly to rifque his hopes. by giving way to his refentment. By devouring in fecret the chagrin which preved upon his heart, he gave an additional thade to the natural glom of his temper. The more he obferved of the contuct of julin, the more deeply did he regret the lofs of his beloved

Vipfania: 


\section{$\left[\begin{array}{ll}7 & 79\end{array}\right]$}

Vipfania; and fo greatly was he affected by an accidental interview with this lady, who was now marricd to Afinius Galles, * that by the emperor's command care was taken that they fhould meet no mure. In the houfe of her fecond hutband, tania was delivered of that child on whom Tiberius had fondly placed his hones. He z̧are the name of Drufus to this fon of his love, and treated him through life as the fole object of his affection.

* Alinius Crallus was the fon of A. Polito, the Aicre of Augutus, and the patron of Virgi, who adirefss of him his not eslebrated eclonge. 


\section{[ 80 ]}

\section{CHAPTER III.}

Agrippina's infant Character; Care of AUGUSTUs in her Education; contracted to Germanicus ; her Mother's Profigacy and Wretchedness.

CONTINUED TO THE $753 \mathrm{D}$ YEAR OE ROME, BEING THE FIRST YEAR OF THE CHRISTIAN A.RA.

HAVING given fuch a fketch of the 1 events which preceded the birth of Agrippina, and of the characters with whom the was moft nearly connected, as fcemed neceffary for the purpofe of elucidation, we fhall now attend more clofely to the inmediate fubject of the prefent Memoirs, 


\section{[ 81 ]}

Agrippina loft her father at a period when the mind is happily infenfible to miffortune. Surrounded by all that could gratify or amufe the infant fancy, the felt no diminution of happinefs, no interruption of enjoyment. Perceiving herfelf a particular object of attention to him whofe fmiles imparted the glow of fatisfaction, and whore frowns were dreaded as the wrath of heaven, the could not avoid, even at a very early age, feeling the complacency of felf-importance; a feeling which we may prefume the obfequioufnefs of domeftics, and the flattery of friends, did not tend to diminih. The young favourite of the emperor was not likely to be often vexed by contradiction. Even Livia, whatever averfion the might fecretly entertain, would, according to the maxims which governed her condust, proportion the ardency of her careffes to the depth of her malignity. The fame means which had been taken to corrupt the mind of roL. 1. o the 


\section{$\left[\begin{array}{lll}8 & 82 & 1\end{array}\right]$}

the mother might have been adopted with equal fuccefs to deprave the principles of the daughter; but happily for Agrippina, the was foon removed from the dangers and temptations, which, in the houfe of Auguftus, might have enfnared her unfufpicious youth.

According to the ancient cuftom of the Romans, the was contracted in infancy to Germanicus, the fon of Drufus and Antonia, who was then a boy about her own age. Marriages formed in this arbitrary manner cannot be fuppofed to have been often productive of matrimonial felicity. The mifery attendant upon fuch unions was expected to be obviated by the facility of divorce; but it was foon found that the remedy was in itfelf an evil more pernicious than that which it was intended to remove. Divorces had at all times been authorifed by the Roman laws, but (fuch was the virtue of the early ages) were long without example in the Roman hiftory : 


\section{[ 83 ] $]$}

hiftory; their frequency, which may juftis be confidered as the criterion of general depravity, was now productive of all the evil confequences that can arife from giving legality to proftitution. Auguftus, though he had himfelf abufed the liberty of divorce in a moft licentious and thameful manner, no fooner became intent upon the reformation of public morals, than he reprobated the practice as the fource of their corruption. He iffued edicts, he promulgated laws, to check the growing evil. But alas! neither laws nor ediets can alter the nature of things. When luxury and its attendant vices have pervaded all ranks, and univerfally vitiated the morals of a powerful and wealthy people, vice is not to be controled by the authority of legiflative wifdom. In fuch a ftate, nothing fhort of national calamity can prove a corrective of fufficient efficacy; but to this ftate of univerfal depravity Rome had not yet fully arrived. Virtue had ftill many vota- 


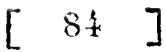

ries; and in the midft of a corrupt fociety a number of illuftrious citizens ftill preferved the purity of unblenthed reputation.

Of this honourable defcription were the parents of Germanicus. 'The character of Drusus has been celebrated by moft of the poets, and all the hift rians, of the Auguitan age. It is impreffively delineated by one of the latter, who fays, that Drufus was "a youth of as many virtues as prudence can accquire, or human nature can admit."* His military talents engaged the affections of the army, while his amiable manners endeared him to the people.

The virtues of Antoniat were not lefs sminent, or lefs worthy of univerfal efteem, that hofe of her hulband. Though difzinguifhed by bcauty and wory perfonal accomplifhment, the was ambitious of a

* Vellei s Pater cuhis.

t See. Note $\mathrm{C}$. at the end of the rolume.

ligher 


\section{[ 85 ]}

higher title to admiration than beauty or perfonal accomplifhments can beftow.Wifdom and prudence, tendernefs and fidelity, were the honourable characterittics of the wife of Drufus. Attached to each other by every tie of affection and efteem, Drufus and Antonia prefented to a diffolute age a rare example of connubial happinefs. But alas! fuch happinefs was not doomed to be of long duration. The amiable Drufus, loaded with early honours, was, in the midft of his career of glory, fnatched from an admiring world. After having, for his fuccefs in the wars of Germany, obtained the honour of an ovation,* and the triumphal ornaments, he returned with the additional dignity of the Confulate to the fummer camp, where he fhortly after expired; leaving to his aftlicted widow no confolation fo foothing. as the remembrance of his virtues. His

* See Note D. at the end of the volume.

death 


\section{$\left[\begin{array}{ll}86 & \end{array}\right]$}

death was lamented by the prince and people with equal fincerity; and the honourable firname of Germanicus was by the vote of the fenate decreed to his porterity, as a perpetual memorial of the virtues and atchievements of their illuftrious anceftor. His fon was deftined to do immortal honour to the name, and in the promifing difpofitions of her charming boy, the heart of Antonia experienced the invigorating folace of hope.

Germanicus was only three years of age at the time of his father's death; how foon he was contracted to Agrippina is uncertain; but as they were equally the care of Antonia, fhe, in the courfe of their education, fuccefsfully cultivated in their tender minds that mutual affection which laid the foundation of their future felicity.

Under her maternal care they were preferved from the contamination of vice, while they were embued with every noble and generous fentiment that can adorn the 


\section{[ 87 l $]$}

human character. Nor was Auguftus lefs folicitous concerning the education of his grand-children, tha! I. e had been with regard to his daughter. His letters to Agrippina were ftill extant in the time of the hiftorian Suetonius; who quotes one that was written to her while the was very young, in which he commends her ingenuity, and among other excellent advices, begs her "to be particularly careful, botb in speaking and writing, to avoid affectation."

Agrippina was endowed by nature with a capacity that rendered the acquifition of knowledge not only eafy, but delightful; and the had the happinefs of being born at a period, when literary tafte had reached its utmolt perfection. 'That impetus which the inftitutions of ancient Rome had given to the human mind was not yet exhaufted; but being now impelled into other channels, produced thofe glorious monuments of genius which have been the admiration of all fucceeding ages.

The 


\section{[ 88 ]}

The love of letters had been fuccefsfully cultivated by Atia in the mind of her fon. In his tafte for literature, Auguftus was no hypocrite. He cultivated the arts of oratory and poetry with fuccefs; but as an author, though defirous of diftinction, he was fuperior to the meannefs of jealoury.

His friend and minifter Mrcenas was endeared to him by a fimilarity of tafte. It was this diftinguifhed patron of genius, who firtt introduced Virgil to the notice of Auguftus. And Virgil in his turn, with a liberality worthy of his talents, introduced Horace to the favour of both. Encouragement gave an additional ftimulus to genius; and under the protection of Auguftus, Latin poetry was taught fuccefsfully to emulate the beft productions of the Grecian mufe. The with of the prince was feconded by the fervour of the people. Of that fervour, with regard to the effufions of poetry, we, in modern times, can form but a very in- 


\section{[ 39 ]}

adequate notion. The Chriftian religion has rendered our ideas of immortality more correct; but in the age of Auguftus, the idea of immortal glory was firmly affociated with every exertion perfonal or mental, that raifed an individual to diftinguifhed renown. Though the Eneid, which would undoubtedly have proved the moft popular of his works, was not publifhed till after the death of Virgil; fuch was the celebrity he enjoyed, that when at any time he came to Rome, the people crouded to gaze upon him with the profoundeft admiration. When he went to the theatre, the audience manifefted their rclpect by rifing from their feats, as was cuftomary on the entrance of the emperor. Wherever he appeared, he received the tribute that was due to one who had done honour to his country, and heard on every hand the burft of admiration or the murmur of applaufe. 


\section{[ 90 ]}

It was at this time the cuftom for authors of all defcriptions to read or recite their works to a felect audience of friends and critics, who freely commented upon the faults or beauties of the performance. Virgil had long refifted the intreaties of Anguftus, who was entremely anxious to be favoured with a fpecimen of the Fneid, upon winch he knew he had been for a length of time engaged; when the work was confiderably advanced, the poet fo far yielded to the requeft of the Emperor, as to recite the fecond, the fourth, and the fixth boots, in the prefence of a felect party at the palace. The recent death of Marcellus bad at this time thrown a gloom over the focial board, and Augutus was glad to feize the opportunity of giving a momentary fufpenfion to the forrows of his beloved fifter, by diverting her attention to another object. OEt ivia's attention was foon arrefted. She liftened with tran. quil pleafure to the woes of Priam and of

Hecuba, 


\section{[ 911$]$}

Hecuba, fmiled at the frantic defpair of the Carthaginian Queen, and anxioufly followed the pious hero to the regions of the dead, and faw the fhades of her illuthious anceftors pafs in review before hcr. But when the poet arrived at that celebrated paffage, where he has fo artfully introduced the young Marcellus, as if in perfpective, encompaffed by admiring crowds, who feem in vain endeavouring to ward off his deftiny, the feelings of Octavia were wound to too high a pitch for her eiifeebled frame to fupport; the fainted away, and was with difficulty reftored to life. After the had been fufficiently recoverct, and had time for recollection, the hewed her fenfe of the poet's merit, by ordering him a prefent of ten fefterci for every line relative to her Marcellus, which on the whole amounted to rather more than two thoufand pounds fterling.*

* See Note F. at the end of the volume. 


\section{[ 92$]$}

As a true tafte for the beauties of poetical compofition was never yet found in a mind poffeffed of a limited range of ideas; it cannot be fuppofed that poetry engroffed the favour of Auguftus.

In his eftimation of talents or of virtue, Auguitus was not biaffed by the fpirit of party; he was too confcious of his own fuperiority to have recourfe to the defpicable practice of traducing the character, or under-rating the genius, of an opponent. Though he had purfued Bruius and Cafflus with unrelenting vengeance, he was not offended with the hiftorian Livy, for attributing to them the virtues of confiltency and patriotifm. And though the murder of Cicero threw the moft indelible difgrace upon his own character, he did not feek to juftify the atrocity of that black tranfaction by infinuations that would leffen the merit of the man he had deftroyed. It was, however, a fubject on which delicacy would choofe to be filent, and fo much did one 


\section{[ 993 ]}

one of the brothers of Agrippina fear that he thould incur the difpleafure of his grandfather, by ftudying the works of the unfortunate conful, that upon his fudden entrance he haftily hid the book beneath his robe. The quick eye of Auguftns detected the concealment; the poor boy was made inftantly to produce the hidden treafure, and while the emperor turned over the pages with ferious attention, ftood in trembling expectation of a fevere rebuke. His apprehenfions were groundlefs. Auguflus returned the volume with an approving fmile, faying, "My dear boy, the author of this book was a wife man, and a lover of his country." It is, perhaps, feldom that the children of a prince have been thus permitted to reap inftruction from the enemies of their family!

The ambition of Aurgutus was not tinctured with the littlenefs of vanity, He knew that to give popularity to his government, it was more material to render his 


\section{$\left[\begin{array}{lll}9 & 1\end{array}\right.$}

fubjects happy, than to make an oftentatious difplay of his own wealth or confequence. While he poffeffed an abfolute dominion over the lives and fortunes of his former fellow-citizens, he affected no external appearance of fuperiority, but lived in every refpect like a private gentleman of moderate fortune. The houfe he occupied was far from being one of the beft in Rome; nor was it furnithed in a manner that was either fo magnificent or expenfive, as thofe of many other fenators.* His table was remarkable for the fame plainnefs and frugality ; but to thofe who poffeffed a tafte for the pleafures of converfation, it never failed to afford a moft luxurious treat. His parties were ufually fmall, but they were

* "His frugality in the furniture of his houfe ap. parrs even at this day (viz. in the time of Suetonius) from fome beds and tables, fill extint, moft of which are farcely fit for any gented private fanily. It is reported, that he never lay upon a bed but fuch as was low and meaniy fumilhed. He flum sore any garmoni but what was nade by his wife, filtor, daightor, and grand-danghers." - Suct. fas. 73 . 


\section{[ 956$]$}

enlivened by wit, and adorned by genius and wifdom. All the young perfons of the family were placed at an adjoining table; and had the advantage of liftening to the various fubjects of difcuffion or of criticifm that engaged the attention of their feniors. Sometimes a pocm or a play was read for the amufement of the company, who afterwards delivered their opirions upon the merits of the compofition. 'Tho' decorum was preferved, rellraint was banifhed from the focial board, and in the houfe of Augutus the guefts forgot that Rome had now a mafter.

With the leffons of prudence and wiftom the ardent mind of Agrippina imbibed the generous fpirit of independence. The haughty Livia foon faw that her arts were detccted, and her character abhorred; her hatred to Agrippina was increafed by the conviction, and its rancour foon extended to all with whom the wa, connected. The growing attachment of her grandfon to 


\section{$\left[\begin{array}{ll}96 & ]\end{array}\right.$}

his betrothed wife gave to her malignant mind a pang fuch as a demon may be fuppofed to feel; and while they were united in the love and admiration of all their other relatives, they were alfo united as objects of equal averfion in the breaft of Livia.

A daughter who was elder, and a fon who was younger, than our hero, fhared the maternal care of Antonia. The former, named Livilla, was foon contracted to Caius Caefar, the brother of Agrip. pina; and as the by this means came under the authority, and was fubjected to the influence, of her grandmother Livia, the infamy of her after-conduct may be eafily accounted for. She and the younger fifter of Agrippina were equal victims to the corrupting arts which had deftroyed the innocence of Julia; who was now running the career of depravity without flame and without reftraint.

The hufband of Julia was no franger to the infamy of her conduct. He knew 


\section{[ 97 ]}

that in the life-time of Agrippa the tongue of fandal had not been filent: and was aware that Sempronius Gracchus fill carried on the criminal intimacy, which was then fufpected to have taken place berwixt him and Julia. Tiberius buried his refentment in the dark recefles of his breal?; but he marked Sempronius Gracchus for future vengeance.

It is the nature of vice to be progreffive. The imagination of Julia had fint been foiled by the admifion of impure ilieas; the fecond ftep in vice was a breacly of her marriage rows, which was probalyly excufed to herfelf by the falle and pemicious notions of the irrefintible infience of $f y m$. pathetic tendernefs. The arts of the feducer might aid the fophiftry of panfion; but the rioman who has forfeited her honour, cannot long retain thut feif-refped which is the fupport of every virtue. She who ccafes to be chate, will foon ceafe to be aniable. Julia, infear of being lumbled rol. I. IX

by 


\section{[ 98 ]}

by the confcioufnefs of guilt, became more. proud and arrogant. She defpifed Tibe. berius, and taking advantage of her fupericr birth, and the favour of Auguftus, the took every opportunity of evincin's her contempt. Nor was fhe long contant to her firlt feducer. Another and another fucceeded lim in her favour, till at length in her coufin Marcus Julius Antonius the found a paramour equally abandoned as herfelf. Antonius was the fon of the triumvir by Fulvia, and inherited all his father's profligacy without any pretenfions to his talents. His half-fifter Antonia was not more remarkable for the poffeffion of every virtue, than he was for the practice of every vice. The unfortunate Marcella, who was divorced from Agrippa, in orcier to make way for his marriage with Juila, was deftined to receive Anto. tonitis as her fecond hufband: and this near connexion with the family of Auguftus, gave an eafy accefs to Antonius in the profecution of his intrigue. 


\section{[ 99 l]}

Long did the clofe and fullen mind of Tiberins brood in filence over the deepfelt injury. Diffinulation and concealment converted malevolence into a chronic difeafe of the mind, which no alteration of circumftances could remedy.

From inflicting mifery on Julia, he hoped to experience fome alleviation of his own. To divulge her conduet to Auguftus, was a ftep which to his fufpicious temper appeared fraught with danger: he therefore preferred a plan of retirement which was better fuited to the gloomy habits of his foul.

Caius, the eldeft fon of Julia, and heirapparent of Augutus, was now fpringing into manhood; he and his brother Lucius had both been prefented to the fonate, honoured with the nane of Carar, and loaded with dignities which had never before been conferred on youths of their tcnder age. Tiberius, under a plea of delicacy, requefted permifina to retire, that he might not ftand 


\section{[ 100$]$}

in the way of their preferment. He had already borne all the public offices of the ftate, had been twice conful, and had for five years been invefted with the tribunitian authority. The refignation of fo many honours had the appearance of forbearance and huinilicy; but Auguftus faw the mifanthropy of his heart. He refufed his permiffion to the departure of 'Tiberius, in which he was fupported by Livia, who was much incenfed at a plan which hle conceived to be weak and impolitic, and which the feared would effectually impede the execution of her own defigns. But Tiberius was firm. He avowed his intention of ftarving himfelf to death, if he were difappointed ; and had actually been fome days without food, when a paffiport from the emperor faved his life to be the fourge and bane of the family of his bencfactor.

He immediately quitted the city, accompanied by the reiuctant Julia. Out of refpect to the fon-in-Jaw of the cmpe- 


\section{[ 101 ]}

ror, many perfons of diftinction attended them to the place of embarkation; but the gloony cynic maintined impenetrable filence on the road. He arrived at Oftia without having opened his lips to any one of the company; and at parting only coldly faluted a few of thofe who had fo lindly attended him. *

The ifland of Rhodes was the place chofen by Tiberius for his retreat. Thither he and his fmall fuite arrived in fafety; and to a mind at eafe the beauty of this celebrated fpot might have afforded the moft livcly fenfations of delight. But it is difficult to fay, whether Tiberius or his wife was leatt qualified to enjoy the charms of nature. The fubline or the beautiful can produce no correfpondent emotions, where malignity or fenfuality have taken poffeftion of the heart. To impurity or malevolence the exquifite gratifications of refined tafte are unknown. 


\section{[ 102$]$}

Julia, awakenci from her dream of pleafure, was purfued by the gnawing worm of felf-reproach. She found herfelf in the power of the man fhe had injured and hated; and while fhe walked in folitary forrow through the Rhodian groves, the could only look back to feenes of infamy, or forward to the horrors of mifery and difgrace. In the awfu! filcnce of retircment, the fhade of Agrippa and the images of her children alternately arofe to her inagination. The former with a frowning afpeet accufed her infidelity; the latter, cloathed in infant innocence, reproved her foul defertion of the maternal character. Every recollection of the arts of Livia fixed a venomed thaft in her lacerated heart. She too late was fenfible, that in forfaling the parths of virtue, fhe had involved not only herfelf, but her offspring, in a labyrinth of evil, from which there was no pollibility of efcape.

Auguitus had given peace to the world, but he could not ftill the paffions of the guilty 


\section{[ 103 ]}

guilty breaft. He hat exalted his fimily to the pinnacle of human greatnefs, but while they looked down with pride on all that dwelt upon earth, they felt not in the fituation to which they had been raifed any real felicity. To the imperial family, Iowever, did all the various nations which bowed beneath the yoke of Rome, direct their eyes with emotions of envy or admiration. The power of Auguftus was felt in the remoteit regions. Throughout every province of the empire lis will was law. "But ilwougly be meant noi fo, neitiser did bis beart tbink fo," he was but an inftrument in the band of Provitence for fulflling the etemal purpoles of Divine wifdom. To this end, the peace which he eftablihed, the ordinanees which he iffued, and the rules of government which he adopted, were alike conducive. " He fent forth a decree that the world hould be taxed," and that decree, by leading the blefled Minry to she city of David, cita. 


\section{[ 104 ]}

blined her defcent from the King of Ifrael, to whom it had been promifed, that of him a prince fhould in after times be born, " of whofe kingdom there flould be 110 end."

While Auguftns received from his fellow creatures the homage which was due to the great CREATor; the obfure city of Bcthlchem was pointed out by the ftar of heaven as the refidence of Him "in whom all the nations of the earth fhould be blckfed." To hail the aufpicious event, multitudes of the heavenly holt defcended from on high, and while Auguitus was liftening with complacency to the fattering falfehoods of the Roman poets, angels were on the plains of Judea, founding their glorious harps, "praifing GoD and faying, Glory to God in the bigheft; and on earth peace ; good-will cowards mon!" ".

* See Note G. 


\section{$\left[\begin{array}{ll}105 & ]\end{array}\right.$}

\section{CHAPTER IV.}

Conduct of Livia to Agriprixia and her Brothers.-Lucies Casari sent from Rome.-Caius Casar married to Lrvrlua; sent into Asia--Germavrcus assumes the manly Gown; marricd to Agmipina.

CONTINUED TO THE 756TH YEAR OE ROME; THIED YEAR OF THE CHRISTIAN ERA.

GRIPPINA had too much fenfibility
to be indifferent to the conduct of her mother. It is not indeed probable, that the was made acquainted with her abfolute ginit; but the ideas of propricty which the had imbibed from the dignified demeanour 


\section{[ 106$]$}

of Antonia, colld not fail to be often thockce by the levity of Julia's manners and converation. The pain fhe had thus expericnced would reconcile her mind to a feparation, which in any circumfances muit have been amply recompenfed by the abfence of Tiburius, whofe morofe and fullen muners threw an unwelcome reftraint apon the gaicty of his young relations. From the tinc he parted with Viffunia, there was nothing fo odious to him as the fight of happinefs; and as the vivacity of Agrippina mit have rendered her paricularly liable to offend in this way, it is no: to be wondered that he conceived for her an averfion no lefs cordial than that which The had infpired in the breaft of Livia.

Asrippina, with the thoughtlefiners of youth, derided the impotent hatred of toth fon and mother. Secure of the affections of all who were truly dear to her, the darling of Auguftus, the pride of Antonia, the beloved of Germanicus, had 


\section{$\left[\begin{array}{ll}107 & 1\end{array}\right.$}

in her heart no room for the feelings of malevolence. One kind action would have rendered even Livia or Tiberius objects of intereft to a mind overllowing with affection. But neither Livia nor her fon ever put the gratitude of Agrippina to the teft.

The emprefs, (for fo we may be permitted to diftinguilh the wife of Auguftus) was vexed and irritated by the conduct of Tiberius; but her refentment, inftead of being directed againft its proper object, was, with that injuitice which is the neverfailing concomitant of the malignant parflons, vented on the innocent. Deprived of the object of her affection, if aflection it may be called which is founded in ambition and felf-love, fhe conld not bear to obferve the pleafure which Augutus derived from the company of his grandchildren. Caius and Lucius, whofe education he had fuperintended with unter. ried afiduity, were now the agreeable compunions 


\section{[ 103 ]}

companions of his days. The former had affumed the manly robe, and the title of prince of the Roman youth: the latter was faft approaching to the fame honours, and by the quicknefs of his genius and the boldnefs of his undaunted fpirit, was probably firt in the favour of Augunus, as he certainly was in the hatred of Livia. Confcious of he: ill-will, and no ftranger to his own pretenfions, he was too ardent to be aliays fo guarded in his exprefilions, as not to leave room for a plaufible complaint of difrefpect.

A boy of fourtcen was no match for the practifed arts of one who had grown old in hypocrify and intrigue. A charge of behaving difrefpectully to the emprefs was made out againft the fprightly favourite; and Auguftus was prevailed upon, however reluctantly, to gratify her refentment by funding his grandfon into Campania, under the pretence of profecuting 


\section{[ 109 ]}

his ftudies to greater advantage at a difrance from Rome.

Such a convincing proof of the pernicious afcendancy of Livia mut inevitably frike decp into the heart of Agrippina. She felt the indignity that was thus offered to her brother; but was foothed (fucin was the effects of heathen morality!) by the hopes that a few years would put him in a fituation to be revenged.

Auguftus was now bufily employed in endeavouring to regencrate the public morals, which it had been the eafier bufinefs of his prodeceffor to corrupt. As a means of infpiring the people with a refpect for religion, he increafed the number and dignity of the priefts, and added new honours and revenues to the veftal virgins.* By the death of one of thefe immaculate prefervers of the paladium of Rome, a vacancy occurred about this period, which was to be filled as ufual by a maid 


\section{[ 110 ]}

of noble birth. The fenators were defired to give in the names of their danghters, that their merits might undergo a proper fcrutiny, previons to the day of election. Many who were defrous of being excufed, addreffed themfelves by petition to the emperor; who, exafperated at fuch a proof of Roman degeneracy, fwore by a tremendous cain, that if any of his granddaughters had been of the age required, he hould voluntarily have offered them to fill the honourable offee! Agrippina might perhaps congratulatc herfelf upon fo narrow an efcape; but had the been able to penetrate her future deftiry, the would have deplored the circumtance which deprived her of an afylum, where the might have fpent a peaceful life in the happinefs of fecurity and content!

Brighter feenes than thofe of calm contentment now occupied her youthful fancy. Agrippina beheld her cider brother a vancing to maturity, and by the indulgence 


\section{[ 111 ]}

of Auguitus and the fervility of the fenate, invefted with the public dignities at a much earlier period than ancient wifdom had authorifed, or ancient modefty had pretended to folicit. His proming virtues rendered him an olject of efteen to all, and his fraternal affection feemed the fecurity of his father's family onstis me with Livilla, which was celcbinted wichout oftentation, imparted a pecular fatisfaction to Agrippina, as it clofly connefted her brother with Gemanicus. She was not long permitted to enjoy the hopes that were thus excited. Livia, who drcaded that the confequence of thef numtials might increafe the olfacles which ftood in the way of her ambition, prevaled upon the emperor to honour the young Cafar with an employment that would immediately feparate him from his youthful bride. The command of the legions in Armenia was enirufted to Caius, with an eftabliftment fuituble to his dignity; but in conf-

fideration 


\section{[ 112 ]}

deration of his youth and inexperience, it was thought advifeable that he fhould be accompanied by Lollius, who had been his domeftic tutor, and was ftill permitted to retain fome degree of authority over his former pupil. Lollius, like all who were placed about the grand-children of Auguntus, was the creature of Livia, and it is fufficient to fay that he proved himfelf worthy of the conflence of his patronefs.

The tears which Agrippina thed on the departure of her brother, were thofe of affection and tendernefs, fweetened by the ilea of his preferment, and by the hopes of his returning with glory to the embraces of his family. A ftill darer intereft fuon occupied her heart. Hicr Germanicus was now to change the fhort habit, or pretexta, for the manly robe; a period of much joy to the Roman youth, as it feemed to form a new xra in their exiftence. It may be believed, that no hands but thofe of Agrippina were cmployed 


\section{[ 113 ]}

ployed in preparing the auipicious drefs; and that as the proceeded in the delightful taik, her fancy wove fcenes of future happinefs, bright and fpotlefs as the texture of the fabric on which the was occupied. At length the withed-for day arrived. The young hero, attended by the numerous friends and relations of his family, went in folemn proceffion to the temple of Jupiter, where, after the performance of divine rites, he was invefted with the white $\operatorname{tog} a^{*}$ by the hands of Auguftus; who then lead. ing him into the forum, or great fquare of the city, which was the fcene of all public tranfactions, prefented the fon of Drufus to the affembled multitude. The elegance of his perfon, the opennefs and intelligence of his fine countenance, and the air of modeft dignity which marked his whole deportment, delighted the admiring crowd. Tears of joy bedewed the cheeks of the

* Note I.

VOL. I, 


\section{[ 114 ]}

hardy veterans, who had fought and conquered under the banners of his father. The name of Germanicus, which was endeared to all ranks in the community, was bleft by every tongue. His aufpicious entry into public life was hailed by the univerfal acclamations of a generous and affectionate people, who feemed from inis period to have adopted his interefts as their own.

In thefe delicious moments, the tender mother reaped the rich reward of all her anxious pains and unwearied afliduity. In the bloom of beauty the had withdrawn from an admiring word, and confecrated her days to the education of her children and the memory of her huiband. She now with exultation could compare the. refult of her virtuous determination with the hollow and contemptible triumphs of vanity or ambition. The confcioufnefs of having cherihed in the bofom of her fon thofe virtues which would do honour to 


\section{[ 115$]$}

the name acquired by his father's valour, gave to the widowed heart of Antonia fuch a fenfation of delight, as no votary of diffipation ever yet experienced. We may conceive the feelings with which the pronounced upon this occafion the maternal bleffing; and as the character of Germanicus was diftinguifhed for gratitude and piety, he could not be infenfible to the happinefs he enjoyed in being bleft with fuch a mother as Antonia. His marriage with Agrippina, which muft have taken place before he had attained his feventeenth year, completed his felicity; and could the biographer of real life imitate the example of the novelift, the reader might be left to fuppofe that a life of uninterrupted happinefs was the inevitable confe. quence of the aufpicions union. Happy indeed they could not fail to be, for their happinefs was placed on the folid foundation of an intimate knowledge of eacls other's difpofitions, and a fincere efteem of 


\section{[ 116$]$}

each other's virtues. Nature had beck uncommonly liberal to both in every perfonal charm, and every mental endowment. The vivacity of Agrippina's temper was modified by the mild wifdom of Germąnicus. That haughtinefs which had been nurtured by early indulgence, was foftened, and in the life-time of Germanicus even annihilated, by her refpect for his opinion, and her ftrict ideas of duty; while his gentle virtues was perhaps roufed to greater energy by her fuperior fpirit and vivacity. Antonia found in her a daughter every way worthy of her affection; and the choice of Germanicus was (with the exception of Livia) bleft with. univerfal approbation.

Antonia required the happinefs of Germanicus to confole her for the unpromifing difpofition of her younger fon. Claudius fecincd to have been born with a deficiency of fecling and of intellect, which the would gladly have attributed to a weak 


\section{[ 117 ]}

and fickly conftitution; but the powers of his mind did not ftrengthen with thofe of his body. It is not improbable that her anxiety for his improvement was in fact prejudicial to his faculties. His flow capacity was perhaps urged to the acquifition of knowledge at a period when attention and obfervation were yet weak and defective. As he did not want memory, he learned to read, and even to retain what he read, though it made no impreffion on any other faculty. Incapable of paying that attention to the manners of others that could teach him to form his own, he was perpetually erring againft propriety; and infenfible to the feelings of thofe with whom he converfed, he could not correct himfelf by a fenfe of the impreffion that was made by his conduct. Perhaps his ftupidity was increafed by the injudicious zeal of his preceptors, and the habit of confidering himfelf as inferior to his companions might actually increafe the difparity. 


\section{[ 1118 ]}

Auguftus was little lefs mortified than Antonia at the dulnefs of Claudius. The following letter, preferved by Suetonius, will thew his fentiments upon the fubject in the cleareft light, and at the fame time ferve as a proof of the afcendancy of Livia, without whofe concurrence no ftep relative to any branch of the family was now taken. The letter alluded to muft have been written after the return of Tiberius, and confequently at a later period than we have yet arrived at in the memoirs of Agrippina; but it is now introduced, that the thread of the narrative may not afterwards be interrupted.

\section{AUGUSTUS TO LIVIA.}

"I HAve had fome converfation with Tiberius, according to your defire, my dear Livia, as to what mult be done with your grandfon Claudius at the games of Mars. We are both agreed in this, that 


\section{[ 119 ]}

onte for all we ought to be determined what courfe to take with him. For if he be really perfect and entire, as I may fay, with regard to his intellects, why fhould we hefitate to promote him by the fame fteps and degrees we did his brother? But if we find him indeed unfinihed, and defective both in body and mind, we muft beware of giving occafion for him and ourfelves to be laughed at by the world, which is ready enough to make matters of this kind the fubject of mirth and derifion. We thall never be eafy, if we are always to be debating upon every occafion of this kind, without coming to a final decifion where he be really capable of public offices or not. With regard to what you confult me about at prefent, I am not againft his fuperintending at the feafts of the priefts, if he will fuffer himfelf to be governed by his kinfman Silanus's fon, that he may do nothing to make the people ftare and laugh at him. But 


\section{[ 120$]$}

I do not approve of his feeing the Circenfian games from the Pulvinar.* He will be there expofed to view in the very front of the theatre; you may, if you think proper, give our kinfwoman Antonia this part of my letter to read,"

In another letter he writes as follows:"I hall invite the youth Claudius every day during your abfence to fupper, that he may not ap alone with his friend Sulpicius and Athenadorus. I with he was more cautious and attentive in the choice of fome perfon, whofe motion, air, and gait, might be proper for the poor creature's imitation.

"In things of confequence he fadly fails."

Where his mind does not run aftray, he difcovers a noble difpofition."

Auguftus in a third letter fays, "Let me die, my dear Livia, if I am not altonithed, that your grandfon Claudius fhould

Note K.

declain 


\section{$\left[\begin{array}{ll}121 & ]\end{array}\right.$}

declaim fo as to pleafe me: for how he that talks fo obfcurely, fhould be able to declaim fo clearly and properly, I cannot imagine." Augufus might eafly have explained the myltery. When he declaimed, he ufed the ideas and the arrangement of others; when he converfed, he difplayed the confufion of his own.

Antonia feems to have been fenfibly mortified by the untoward genius of her younger fon: but Germanicus pitied his weaknefs, and ever treated him with tenderners and affection.*

* Note L. 


\section{[ 192$]$}

\section{CHAPTER V.}

Lucius Casar sent to Marseilles; dies by Poison.-A U G U S U S made acquainted with Juln's guilty Conduct; his Grief. -Trial of Julia; her Banishment.Death of CaIUs Casar.-Recal of Tiberius; adopted by the Emperor.Germanicus adopted by Tiberius.

TO THE YEAR 5 OF THE CHRISTIAN ARA.-A. U. C. $75 \mathrm{~S}$

B LESSED in the tender love of her B Germanicus, admired by all who faw, and careffed by all who were dear to her, Agrippina confidered this world as an elyfium, far fairer than the poet's fancy had ever feigned.

Next to her hurband, her brothers held the deareft place in her affection. Lucius 


\section{[ 129 ]}

Lucius had been permitted to return from Campania to affif at her nuptials; and while his improvement did honour to the mafters under whom he ftudied, his appearance indicated a fpirit and capacity beyond his years. On his affuming the manly robe, he was prefented to the people by Auguftus in a fet fpeech, which he concluded by entreating them to grant their favour to the youth according as he deferved it. The honours which had been conferred upon his brother, were by acclamation voted to Lucius; and the friends of the houfe of Cæefar rejoiced in the ap. parent ftrength of the Julian line.

By the advice of Livia, the command of the army in Spain, a province which enjoyed the moft uninterrupted tranquillity, was granted to the young prince, as an initiation into the knowledge of military affairs; and that he might have no time for being injured by the diffipation of the capitol, his departure from Rome, was, by 


\section{[ 124$]$}

the provident wifdom of his ftep-mother, haftened as much as poffible. Who were the companions of his journey, or by what route he travelled, cannot now be accurately known; but Agrippina had the pleafure of hearing that he reached Marfeilles in fafety.

Narfeilles had rifen to renown as a Grecian colony, and was for ages diftinguifhed as a feat of learning, "where" in the elegant language of Tacitus, "the refinements of Greece were happily blended with the fober manners of provincial economy." Its ichools of oratory and philofophy could not fail to attract the attention of a young man of vigorous talents and liberal education; and it was probably with regret, that Lucius took leave of the hofpitable Marfeillans to proceed to the Spanifh camp. Unconfcious as the victim which crops the florrers that ftrew its path to the altar on which it is loomed to bleed, Lucius feized the pre- 


\section{[ 125 ]}

fent moment of delight, and expected that futurity would only vary the fcene of pleafure. But alas! before he lcft Rome, his fate had been decreed by Livia. The morning's fun which was to have guided him on his journey, beheld the unhappy youth a lifelefs corfe. The firt bloody facrifice offered by the emprefs at the lhrine of ambition!

By whom the poifon was adminiftered is not clearly afcertained; and as all enquiry concerning it was qualhed by the authority of her whofe deed it was mont juftly confidered, the name of the flave who was the blind inftrument of her cruelty, has not been deemed worthy of notice by any hiftorian.

A deed which filled Rome with horror and indignation, could not fail of making a ftill decper impreflion on all who were more immediately intereited in the fate of the unhappy youth. Thofe lively feelings which diftinguifhed Agrippina, and ren- 


\section{[ 126 ]}

dered her through all the fcenes of her darkly-chequered life peculiarly fufceptible of happinefs or mifery, brought agony to her heart. Alternately a prey to grief, to fufpicion, and to the moft diftracting apprehenfion, for the lives of her remaining brothers, it would have been imporfible for her in the prefence of Livia to have reftrained the emotions produced by the conflicting paffions of her foul. Germanicus faw the danger to which the might be expofed, and wifely prevailed upon her to withdraw from obfervation. Soothed by the endearments of tender fympathy, the liftened to the wife remonftrances of her hulband; and while fhe bedewed the memory of Lucius with her tears, abftained from complaint or accufation.

Whatever were the feelings or the fufpicions of Auguftus on the tragical fate of his favourite grandfon, he did not betray fuch fymptoms of emotion as could lead to their difcovery; but left his mind, if 


\section{[ 127 ]}

permitted to dwell without interruption on the melancholy fcene, flould gather ftrength to turn on the viper whofe venom threatened perdition to his blood, it was deemed neceffary to direct his attention into an other channel.

The art of Livia, always fruitful in invention, contrived that the guilt of Julia fhould all at once burft on the mind of her unhappy father. Pride the well knew to be in his bofom a fill tronger feeling than paternal affection. Nor was the difappointed in her expectations. No fooner was Auguftus convinced of his daughter's infamy, than all the feelings of indignant honour thook his difordered foul. Shame and rage, grief and refentment, alternately took poffeffion of his heart, till by the ftruggle of contending paffions reafon had nearly loft her feat.

He imprecated vengeance on the head of his child, he curfed the hour of her birth, and, as if he had wilhed the whole 


\section{[ 125$]$}

world to fympathife in his defpair, he fere a letter to the fenate, defcribing in the mot lively colours, the aifgrace of Julia, and the anguin of his heart.*

A bill of divorce was infantly difpatched to Tiberius, with orders to fend the unhappy Julia to Rome, there to expiate by death the crimes which had fullied the honour of her illuftrious family. Letters from Livia accompanied this difpatch, which apprifed Tiberius that his fupplica. tions in favour of his wretched wife would redound to the honour of his own clemency, but that there was no room to fear that they would have any effect in foftening the ftern heart of her incenfed father.

Tiberius obeyed the imperial mandate with real joy, and well-feigned reluctance.

* Armutus foon repented of this indiferect expo. pofme cis his daughter's guilt, and bitterly lamentad the rathnefs with which te had thus pubithed the fcand:l of his houfe. "Ji Agrippa or Macenas had liven," he was heard to fay, "I hould have been re. fri:ned from this act of imprudence."-Seneca, as guosed by Targufon. 


\section{[ 129 ]}

He interceded for his guilty wife with fuch an appearance of candour and magnanimity, as was calculated to make her conduct appear ftill more inexcufable in the eyes of Auguftus and of the world. But his character was already too well known to gain much credit, either with the emperor or the public, for pity or fincerity.

Agrippina heard with horror of her mother's crimes. Her virtuous mind was fhocked at the idea of fuch impurity; her filial piety was wounded by being obliged to condemn the conduct of a parent. In trembling fufpence the waited the hour of her arrival; now dreading that life might be the forfeit of her guilt, and again wifhing that her crimes and forrows might be buried in a watery grave. In the mean time, Sempronius Gracchus and Julius Antonius, the lovers of Julia, were brought to trial. They were both condemned: the former to perpetual banifhment, the latter to fuffer an ignominicus vol. I.

$\mathrm{K}$ sitath. 


\section{[ 130 ]}

deativ. No one called in queftion the jutice of the fentence. Gracchus had betraycd the confidence of friendfhip, and while he was under many obligations to Augutus and his fon, had, by the feduction of Julia, brought difionour on all with whom the was connected. Antonius was involved in fill deeper guilt; to the ties of friendhip he added thofe of blood, and the crime of adultery was aggravated by the fin of ingratitude. Yet his puniflrmént was to a Roman lefs dreadful than that of his fellow-delinquent.*

The fate of Julia was perhaps more terr:ble than either. Auguftus retracted the fentence of death, but doomed the once gay and thoughtlefs Julia to hopelefs exile. A confcience filled with remorie, and a mind enervated ty diffipation, are wretched companions in retirement; what mut they then prove in a folitule never to be cheered by hope, never to ise interrupted by foci- 


\section{[ 131 ]}

ety! The ifland of Pandatoria, (now Santa Maria) in the Tufcan fea, was fixed upon as the place of her confinement. Thither the was hurried, wuthout being permitted to take a laft leave of her children; and by the commands of Auguftus divefted of all the ornaments of her rank, and humbled by the mean attire of a plebeian.

It was reported to the emperor, that Phoebe, the freed-woman and confidante of of Julia, (whom we may, without impropriety, conjecture to have been one of thofeemployed by Livia to corrupt the unfufpecting innocence of her youth) had in a fit of remorfe hanged herfelf. "WouldI had been the father of Phocbe, rather than of Julia!" was the emphatic reply of Auguftus.*

The wound which a mother's difgrace had inflicted in the filial heart of Agrippina ftill continued to bleed, when the promifed return of her elder brother gave a falutary check to her afliction, and re- 


\section{[ 152$]$}

vived the drooping fpirits of her family. The prefence of Caius was anxioully expected by his fifter, not only on account of the pleafure fhe naturally hoped to receive in the fociety of a beloved brother, but as The thought it neceffary to the fupport and protection of his relations, and of his younger brother in particular. Poor Pofthumus had been in infancy awed into timidity by the harh aufterity of the emprefs; but the unfortunate boy had an ingenuous temper and an affectionate heart; and to his finter the natural kindnefs of his difpofition was thewn without difguife. She encouraged him to hope that the reftraiut in which he was now held, was foon to terminate; and that on the return of Caius he would find a friend, who had fuf. ficient intereft with Auguftus to counteract the infidious arts by which Livia fo fuccefsfully endeavoured to create a prejudice againt his unoffending innocence. The confular dignity, to which Caius had becn 


\section{[ 133 ]}

clected, could not fail of arming him with fuch an authority as might be fatal to the murderers of the unhappy Lucius. His arrival was expected with impatience by all who either hated the arrogance or dreaded the refentment of the haughty Livia; and it is probable that his young bride, whom he had been obliged fo precipitately to leave, was not fo devoid of attachment to the gallant youth, as to think with indifference of the expected moment that was to reftore him to her arms. But alas! that moment was never deftined to arrive. While the indulged the dream of happinefs, Livilla was already a widow!

The heavy titings of the prince's death were brought by a courier from Syria; for fo far had the ill-fated Caius proceeded on his journey homeward from Armenia, when a fatal period was put to his progrefs and his life. Conlternation and difmay fpread through the palace, and from the palace were foon diffufed over the city. 


\section{[ 134 ]}

The account fuccinctly ftated, that he had died at Lydia, and that his death was occafioned by a wound.

From what hand was the wound received? was the general queftion.

The anfwers were vague and contradictory; nor did any ftatement of the fact ever appear that was fufficiently authentic to clear from fufpicion the character of Lollius. The prince's tutor was too high in the favour of Livia, to be arraigned for the murder; but in the public mind he never was acquitted of the charge.

This fecond blow was more than Agrippina could fupport. She now to a certainty was convinced, that both her brothers had been inhumanly murdered by the fame relentlefs hand: for whoever were the inftruments, it was Livia, the cruel Livia, who dealt the deadly wound. The murder of Lucius had been attributed to perfonal malice, and particular refentment for a fuppofed offence; but in the 


\section{[ 135 ]}

death of Caius the views of the emprefs were too palpably difplayed to admit of doubt. 'To open the fucceflion to Tiberius, the two princes were cut off in the bloom of youth, and the career of glory; when their opening virtues had juft began to attract the efteem and admiration of the world. Would the unhappy Pofthumus long remain the only furviving obftacle to his ambition? Alas! in the fate of his brothers all faw the doom of the unfortunate boy, whofe mind had been purpofely injured in hopes of giving a thew of juftice to the blackeft inhumanity.

The guilt of Livia was known and abhorred; but who dared accufe the wife of Augutus of the crime of murder? That noble intrepidity which braves all perfonal danger in the caufe of juftice and humanity, is the inheritance of freemen; the cautions policy of felfifhnefs is the only wirdom known to flaves. 


\section{$\left[\begin{array}{lll}156 & {[}\end{array}\right.$}

The introduction of domeftic aflaffination was confidered by the Romans with horror, and the who fet the firft example of a deed fo atrocious, was detefted by every honeft mind; but the murmurs of indignation were fecret, and fuch was the degeneracy of the times, that they who were confcious of having uttered them with moft afperity, were perhaps the foremoft to pay their court to the emprefs, in order to conceal their guilt.

The malign infuence of Livia over the mind of Auguftus had already alienated his. heart from all who had a natural claim to his affection. She, and the alone, was now neceffary to his happinefs. The compofure with which he bore the melancholy fate of his fons, was confidered lefs as a proof of fortitude than of infenfibility. The courtiers, with admirable verfatility, took the torie from the fovereign, and ceafed to mourn thofe whom Cafar had ceafed to lament. The pious refignation 


\section{[ 137 ]}

refiguation was approved by the fmiles of Livi, and the names of Caius and of Lucius were foon configned to oblivion in the regions of the palace.

The foul of Agrippina was fuperior to difguife. She could nor even bear the appearance of being impoled upon by the hypocritical fymparhy of the wretch who had embrued her hands in the biood of her beloved brothers. Refpect for Germanicus might feal her lips; but no confideration could prevail on her to affume the femblance of efteem for the woman the abhorred. Her prefent fituation was an apology for retirement, and the birth of at fon gave a new object to her follinilute. The anguifh of her heart was foothed by the feelings of maternal tendernef, and in the moment that the prefented the little Nero to the arms of Germanicus, the might poffibly forget that the land ever been aflicted. But forrows fuch as the had c:sperienced, give too deep a tone to the fect- 


\section{[ 138 ]}

ings, to admit of an immediate change. It is more than probable, thit while fhe hung with a mother's fondnefs over her fleeping infant, the dangers to which he might hereafter be expofed, would invoJuntarily intrude upon her faucy, and by the anguilh of anxiety chaften the fervour of hope.

While the cruel Livia was paving the way for the advancement of Tiberius, by the deftruction of her hufband's family; the fon of her idolatry was wafting his gloomy hours in the folitude of Rhodes, a prey to abortive malevolence, and unavailing difcontent. Auguntus, with all the appearance of fuavity and complaifince, could not brook the fhadow of oppofition. The love of power had been the ruling pafion of his life. He had now for years been accuifomed to defpotic fway. His word, nay even his look, was confidered as law, by all who approached him. Livia took advantage of his weaknefs, and made this tenaciouf. 


\section{[ 139 ]}

tenacioufnefs of authority the infrument of her ambition. By an appearance of abject fubmillion to kis will, the governed him with an authority more abfolute than he had ever ruled the meanet finve. She hoped that the had taught Tiberius an equal flare of diffmulation. But the ftubbornnefs of his temper, and the ftrength of his paffoons, made him fomeri hat of a lefs accomplifhed hypocrite. Thou?h oppofed by Auguftus in lis fullen refolution of retiring from Rome, he had obntinately perfited in the defign; the hopes of being able to puninh, or at leaft to morrify his wife, being at that time a motive more powerfal than the fear of the emperor's refentment.

That he did not put an end to his uncafinefs by the murder of Julia, is rather extraordinary; but as we cannot fuppofe him to have been reftrained by any foruple of confience, we may believe that he rias deterred by a fear of detecition; ort that as Julia was furrounded by her own people, 


\section{$\left[\begin{array}{lll}1 & 1 \div 0\end{array}\right]$}

and treated with all the refpect due to he: rank, he might even snd it impuffible to execute fuch a plan of vengeance. If he indeed ever harboured fuch a fcheme, and was obliged to relinguith it, the difap. pointment would not fail to add to the irkfomenefs of his fituation. Be that as it may, he foon became difguied with retirement, and folicited the emperor's leave to return to Rome. But Augufus determined to mortify that pride which had dared to oppofe his inclination. Hefternly refufd compliance with his requeft; and upon a fecond fupplication, in which $\mathrm{T}$. berius mof humbly declured, that his only intention in retiring from lome was a point of delicacy with regard to the ycung princes, who were now of an age to fecure their own digrity, and to cbviate all fufpicions of rivalhip) ; and lis only motive for defiring to retum was the with of vifting his beloved relations; Aughtus replied, that " he might lay alide all concern for 


\section{[ 1418$]$}

his relations, whom he had left with fo much indirerence." "*

On the condemnation of Julia, he again renewed his folicitations with no better fuccefs; and as the friendihip of courtiers is regulated by the favour of the monarch, it was no fooner imagined that he was in difgrace with Auguftus, thain he funk into an object of univerfal hatred and contcmpt.

Of all the trials to which the human mind is expofed, there appears to be none more difficult to fupport with dignity than a ftate of exile. The annals of ancient liflory prefent upon this fulject to the philofophic enquirer a number of curious and intere?ing facts. We fhall there find, that the fo much adniredvirtue of the herocs and fages of antiquity was a funfhine plant, which expanded its fair folinge in the hour of profperity, but hrunk and withered in the winter's ftorm. Could confcious recitude afford a fufficient fupport in the adverfe 


\section{[ 140$]$}

turns of fortune, we fhould not liave to blun for the pufillanimous wailings of the virtuous Cicero, in the fhort-lived period of difgrace. Could the certainty of public celebrity impart futisfaction to the human mind, Ovid might have fmiled at the vengeance of Auguftus, in the confidence that the name of the poet would be as immortal as that of the emperor. Could patriotifm and courage fuftain the foul, Cato and Brutus might have outlived the triumph of defpotifm, and fmiled at the maliznity of fortune. To brave the tranfient pain of death, is to a mind elevated by the tone of paffion an effort of no great magnitude: but to bear with firmunefs and magnanimity the trials of adverfity, where there is no eye to witnefs, and no fpectator to applicud; to crince the fame refolution, and to practife the fame virtue, in the dreary faale of folitude, as on the theatre of an anming rund; requires the fupport of principles more powerful 


\section{[ 143$]$}

powerful than heathen philofophy could infpire.*

If to minds poffeffed of every moral virtue a ftate of exile appeared a calamity fo very infupportable, we need not be furprifed, that one who had fo few refources as Tiberius, fhould find it ftill more dreadful. His was not indeed without hope of a fpcedy termination; for he could not believe that the intereft of Livia would prove unequal to obtaining any object on which the fet her heart. But he felt the bitternefs of neglect; and a temper already foured by chagrin was fill farther irritated by difappointment. Inftead of thofe liberal purfuits which might have had a falutary influence in allaying the perturbed pafions of the coul, the weat delire of prying into fumity made him addict himfelf to the ficience of aftrology, which the fuperftition of the times had brought into repute. The trial he made of the abilities of Thrafullus, a ccicbrated 


\section{[ 144$]$}

mafter of this pretended fcience, prefents fuch a ftriking a view of the character of Tiberius, and of the fuperftition of the times, that I thall beg leave to give the anecdote in the words of the hiftorian.

"Whenever he chofe to confult an aftrologer," fays Tacitus, " he retired with him to the top of the houfe, attended by a fingle freedman felected for the purpore, illiterate, but of great bodily ftrength. This man conducted the foothfayer, whole talents were to be tried, along the ridge of the cliff on which the manfion ftood; and as he returned, if the emperor fufpected fraud or vain affectation of know. ledge, he threw the impoftor headlong into the feal. Tiberius was by thefe means left at eafe, and no witnefs furvived to tell the ftory. Thrafullus was put to the fame teft. Being led along the precipice, he anfwered a number of queftions; and not only promifed imperial fplendour to Tiberius, but opened a fcene of future

erents, 


\section{[ 145 ]}

events, in a manner that filled his imagis nation with aftonifhment. Tiberius defired to know whether he had caft his own nativity? Could he forefee what was to happen in the courfe of the year? Nay, on that very day? Thrafullus confulted the pofition of the heavens, and the afpect of the planets: he was ftruck with fearhe paufed-he hefitated-he funk into profound meditation-terror and amazement thook his frame. Breaking filence at laft, 'I perceive,' he faid, ' the crifis of my fate; this very moment may be my laft.' Tiberius clafped him in his arms, congra. tulating him both on his knowledge, and on his efcape from danger. From that moment he confidered the predictions of Thrafullus as the oracles of truth, and the aftrologer was ranked in the number of the prince's confidential friends."

Without confulting the ftars, the cun. ning foothfayer might have foretold with certainty, that the ansiety of Tiberius to

VOL. I,

t. know 


\section{$\left[\begin{array}{lll}1+6 & ]\end{array}\right.$}

know his future fortune was prompted by an ambition, which was not very likely to be deterred from the attainment of its object by any confiderations of pity or remorfe.

Eight years did Tiberius fpend in the gloom of folitude, a prey to chagrin, and all the pafions allied to impotent ambition. His temper was not, perhaps, by nature prone either to wrath or cruelty. Had his mother perithed in the hour of his birth, the fon of Claudius Nero might have been virtuous and happy. By early affociating in his mind the idea of glory with abfolute power, the gave the felfifh pafions an atcendancy over the focial; and by teaching him that diffimulation was the firft attribute of wifdom, the exringuifhed the generous principles of truth and honour, and rendered him perpetually liable to the tortu: 2 of fufpicion. The malevolent paffions that were thus introduced into the heart, were augmented by the very 


\section{[ 147 ]}

effort of concealment. Let us not however believe, that they at once conquered every feeling, and extirpated all the fympathetic affctions. Tieir progrefs was gradual; but like the flow difeafe which attacks the vital organs of the human frame, they imperceptibly increafed in malignity, till at length they corrupted the whole mafs.

Upon the death of Caius, Livia renewed her folicitations for the return of Tiberius; whofe prefence was fo neceffary to confole her well-feigned aflıction, that the emperor, foftened by grief, and fubdued by the appearance of fympathy, confented without reluctance to her withes. A conftitu. tion always delicate was now finking under the infirmities of declining age; and the aflifance of a young man noted for prudence and difcretion appeared to Auguitus as a very defirable object. Efteem and affection would have pointed to Germanicus, as the perfon molt eminenty qualified to fupply the place of a lamented fon. 


\section{[ $1+8]$}

The endowments of his mind, the integrity of his heart, and the urbanity of his temper, recommended the fon of Drufus to the favour of Auguftus, and had fecured to him the affections of the people; who eagerly believed, that fhould he fucceed to the imperial dignity, the reftoration of their liberties would be the fole object of his generous ambition. It is poffible, that a knowledge of their fentiments, their hopes, and withes, might impart an apprehenfion that the popularity of a youth fo much and fo defervedly beloved would fhade the fetting glories of his reign. This apprehenfion, added to the knowledge of Livia's hatred of Agrippina, and the fears of having his peace interrupted by do. meftic difiention, was the probable caufe of his determination in favour of Tiberius. But that Germanicus might not be removed from all hopes of fucceflion, the emperor ftipulated with Tiberius, that on the fame day on which he was adopied 


\section{[ 1499 ]}

by him, he fhould on his part adopt Germanicus.

Auguftus, though by the pernicious arts of Livia, he had been in fome meafure alienated from his family, was not entirely devoid of natural affection. The innocent Potthumus, whofe thynefs and timidity had been craftily mifreprefented by the emprefs as fullennefs and pride, was neither over looked nor fet afide. His adoption preceded that of Tiberius, who was confidered by Auguntus as the guardian of his tender years.

What were the fentiments of Agrippina upon thefe feveral arrangements can only be conjectured from a knowledge of her temper, and general mode of thinking and ating. The fatal cataftrophe of her elder brothers could infpire her with little hope in regard to the fate of Pofthumus, who was as much their inferior in abilities as in years. Nor is it likely that the near connexion with Tiberius, whofe children the and her hulband had now become by adoption, 


\section{$\lfloor 150\rfloor$}

adoption, would be at all agreeable to a mind like hers. Her independent fpirit muft have revolted at being thus made fulject to the abfolute control of the man to whom the attrihuted her mother's difgrace, and for whefe fal:e the knew her brothers to have been cruelly facrificed. Whatever were her feelings, the interefts of her family rendered an appearance of acquiefcence in the will of Alugutus an act of duty; and the had too much good fente :o murmur, where the muf inevitably fubmit.

Tiberius fot the cample of the obedience which he exacted. After his adop. tion, he never exercifed any of the rights of a free citizen, but in crery répect became fuhordinate :o his new father; not even taking the libsty of giving freedom $i$ a flave in his orm name, nor of accepting " vy gift or legacy, but as a part of the "low ace which was from that time his due. This oftentatious parade of duty' was amply recompenfei by fubftantial benefits, 


\section{$\left[\begin{array}{ll}151 & ]\end{array}\right.$}

nefits, and the appearance of humility rewarded by unlimited authority. The tribunitian dignity, which in fact was equivalent to fupreme power, was conferred upon him for five years, and was followed by a fpecial commiffion to fettle the fate of Germany. Called by his new office to take the command of the army in a remote province, his abfence relieved Germanicus and Agrippina from the infup. portable burthen which reftraint impofes upon the generous and fincere.

The marriage of Julia, Agrippina's younger fifter, took place about this time, and diffufed an air of cheerfulnefs and joy. Augurtus gave her hand to a noble patrician, whofe family was worthy of the honourable alliance. The character of Paulus Eimilius Lepidus never rofe to diftinguifhed eminence, but he was a man of birth and fair reputation, and as fuch deferved a hetter wife. 


\section{$\left[\begin{array}{lll}152 & ]\end{array}\right.$}

\section{CHAP. VI.}

Bamishment of AgRIPPA POSTHUMU.... Reflectionson the Conduct of AUGusTu . - Domestic Life of AGRIPINA.-Domestic Economy of the Romans. - Importance attached to Education.-Slarcry.Literature.-Popularity of GERMANRrus.

\section{$=$ \\ A. D. 5 Tо 10.-A.U.C. 763.}

GRIPPINA was not long permitte 3 A to enjoy the tranquillity which the abfence of Tiberius was calculated to produce. It did not require her acutencfs of penetration to predict the fate of the un. fortunate Pothumus; but fo willing is affection to $g: a f_{p}$ at hope, that the might fometimes flatter herfelf, that Livia woul.? 


\section{[ 153 ]}

be contented with having rendered the poor youth fo apparently iufignificint, as to be no longer an o'yject of jealoufy or apprehenfion. But Livia argued in a very different manner. By the adoption of his grandfon, Auguflus had thewn that he fill confidered him as the natural reprefentative of his family; and however fuccersful the had been in fixing an inputation of ftupidity and ftublornnefs on the unhappy boy, the unoffending innocence of his life put it out of her power to make him be believed guilty of any pofitive crime. As he advanced to maturity, he might by degrees conquer that mingled fenfation of timidity and pride, which the lis? istherro found it eafy to reprefent as the cestain proofs of an intractabledifpoftion. He was now approaching to his fifteenth year, and hlov'd he be permitted to aftine the manly gown, and to be prefented to the people as the fon of the emperor, the popularity of his elder brothers might be transferred 


\section{[ $15+$ ]}

to him; and warned by their fate, he might, under the protection of Germanicus, be efectually placed beyond her reach. No time was therefore to be loit. By what arguments the provailed won the emperor, it is not eafy to conjecture. But fhe fo far freceeded in her wicked defigns, that Agrippa Pofthumus was banifhed to Planafial, a fmall intand on the coaft of Etrumia, now known by the name of Pinsofi. There, inder the care of able tutors, and with an cftabliflment fuitable to his rank, he was to profecute his ftudies; but none who were acquainted with Livia, harboured an expectation of his return.

Auguntus, confcious of the opinion that would be entertained of this event, apologifed for his conduet, by declaring that the boy was rude and uman:geable; but the meeknefs of his fubmition, and the innocence of his life, contradieted the afertion; and the weatnefs :' an uxorions hutban? tamely yieiding to the afcendancy of a 


\section{[ $\begin{array}{ll}155 & ]\end{array}$}

wicked wife was confidered as the true explanation of the tranfation.

Accuftomed from our early years to hear the reign of Auguftus mentioned as the mot glorious period of hiftory, ail the ideas which conflitute our notions of a hero are affociated wirh his name. Daz. zled by the fuccefs which attended his ambition, we too readily forget or pardon the crimes by which it was polluted. A flattering and exaggerated portrait of his virtues was the reward of ins patronage of literature; and the viccs of his fucceffors gave to the reprefntation all the force of contratt. But when we lay afide all partiality and prejudice, we fhall view in Auguftes a friking example of the vanity of ambition, and the inconfintency of human pride. He who was filuted mater of the univerfe, before whom kings fell proftrate, and to whofe tatues divine ho. nours were offered, was himfelf the flave of an imperious woman. He who had conģuered 


\section{[ 156 ]}

conquered the legions of Brutus and of Anthony, and who had triumphantly trampled on the expiring embers of liberty, wanted either the power or the refolution. to protect his own oflspring. Enfnared by the arts of an infidious hypocrite, he tamely permitted the cruel deftruction of thofe children whofe infancy he had cherithed with all the fondners of affection, and whofe education he had watched with all the ansiety of parental tendernefs. Had the angry ghoft of Cicero demanded a fitcrifice, the offerings made by Livia of the fons of Julia would have appeafed its utmolt vigeance. But Augufus, lulled by the voice of hittery, appeared infenfible to the ignominy of a conduct marked by pufillanimity and guilt.

The five years which followed the banifhment of Pothumus, were paffed by Agrippina in the bofom of domentic peace. Two other fons were in timit period added to her family, who had the names of Drufus 


\section{[ 157 ]}

and Caius; and thefe, with their elder brother Nero, were little defs dear to the emperor than to their parents. Auguftus was not only foid but proul of his greatgrand-children; and uron hearing that a fevere tas upon bachelors had excited murmurs among the young nobilicy, he camict thefe infunts to the theatre, and holding Caius mon his own knee, while he pliced Nero and Brufus on their father's, he fignificantly pointed to the children and to Germinicus, faying that " none need be aflamed to imitate the example of a young man fo defervedly refpectable."**

Germanicus dia not fand in need of the encomiums of Auguttus to recommend him to popular applaufe. He was already endeared to all ranks in the community, and had the rare felicity of enjoying univerfal eftecm, whithout exciting the malevolence of envy. In G.rmanicus were feen the dignified virtues of an ancient 


\section{$[158]$}

republican, blended with all the graces of modern politenefs. Fond of literature, he was learned without the oftentation of learning. Gentle and modeft in his manners, yet known to be brave, intrepid, and magnanimous. While his vigorou talents were equal to the moft ardent enterprize, and would have fuftained with dignity the weight of empire, his ambition feemed confined to the fole ohject of an unifpotted reputation. Early taught by the precepts of Antonia to conficer virtue as the trueft glory, Germanicus didained all other objeets of purfuit. His liberality was untinctured by vanity, and his charity flowed from the pure fource of a benevolent heart.

In the faithful affection of fuch a hufband Agrippina could not fail to enjoy the mon exalted fpecies of human felicity. Infpired by the fame tafte, they equally difdained the puerile amuements which ate necefiary to fill the heavy hours that would otherwife be infupportable to the rich and iule. Minds fo accomplined as thofe of 


\section{$\left[\begin{array}{ll}159 & 15\end{array}\right.$}

this amiable pair are too opulent to require the aid of fuch poor refources. Sufceptible of all the delinate and refined pleafurcs which the contemplation of the works of genius can produce, they devored their leifure to the fiudy of the beft authors, and enjoyed the luxury of converfing with the moft illuhrious cimaters.

Germanicus and Agrippina, like others of the fune rank, divided their time betwixt town and country. But while the country-houfes of Hecenas, and even of Horace and of Tirgil, were fo confpicucus as to have antraced the attention of polerity, no veltige remains to point out the refilence of Gemanicus. It is therefore probable, that the fame fimplicity which diftinguthed his muners dictured the choice of his habitation; and that white ahnoft the great men of Rome vied with each other in the number and the elegance of their rural villas, " the fon of Drufus was 


\section{[ 160 ]}

contented to confer dignity upon the place of his abode, inftead of feeking to derive confequence from its magnificence.

Whether in town or country, the crowds of clients who were eager to hew their refpect by a perfonal attendance on their patrons, and the number of flaves appropriated to every departmont of the domeftic economy, renderedretirement, frictly fpeaking, impoffible to a perfon of high fation. Auguftus, when he wifhed to be free of all interruption, went to the houfe of one of his freedmen, where he found himielf at liberty to read or write without fear of intrufion; and when indifpored, commonly took up his refidence with Mrecenas. So difficult was it to find repofe in the habitation of a prince!

The fuperintendance of the family, which in former times had formed an effential part of the duties of a wife, was in thele days entrufted to a number of deputies, who in their feparate deparments exercifed an alyfolute 


\section{$\left[\begin{array}{ll}161 & ]\end{array}\right.$}

folute authority over the inferior domeftics. This delegation of truft was more or lefs definite, according to the character and abilities of the miftrefs. While thofe who had like Agrippina been educated in the fobriety of republican manners, ftill confidered an attention to houfhold economy as one of their primary duties ; fuch as had imbibed the modern ideas of pleafure, gave themfelves neitber care nor trouble concerning any domeftic arrangement. The houfes of the latter confequently cxhibited fcenes of diffipation and extravagance, fuch as modern folly can never hope to equal.*

In the houfe of Germanicus riot and confufion were unknown. The number of domeftic flaves rendered it neceffary to inftitute a rigid difcipline; but as obedience to rules is always lefo grievous thon fubjection to caprice, it may be inferred, that thofe who lived under the roof of Germa-

* Note P.

VOL. T. 


\section{[ 162 ]}

nicus and Agrippina, had no reafon to complain of any peculiar hardhip.

That contempt for indolence which the ancicut Romans had been at fo much pains to cherifh as a republican vit tue, continued ftill in fome degree to operate, and to diffufe a fpirit of activity through every part of the domentic economy. The times indeed were now approaching, when idlenefs, under the aufpices of folly and vanity, was to be broughi into fafhion, and confidercd as cne of the difingunthed priviteges of the great ; but as weare inforned that duguftus never wore a robe which was not fabricated by the hands of his wife, his daughter, or his grand daughter, we may infor that the Koman ladics of his time rere in general frangers to idleaefs and emmi. And if

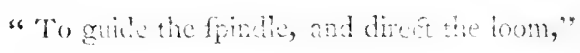
were fill confinedes part of the efential duties of a virtunes matron; we have every reafon to conclude, that in the apartment 


\section{[ 163$]$}

appropriated to the various branches of domeftic manufacture Agrippina was no ftranger.

Every thing was made at home. And though luxury had ere now introduced the fafhions and the fillis of Perfia, pride, or thame, or economy, prevented the Ro. mans from wearing the productions of a foreign loom in the ftate in which they had been imported. The webs of filk were unravelled, and wrought up anew with an equal mixture of linen or woollen yarn: An opportunity was thus given for the difplay of tafte in the invention of new patterns. Agrippina, while the arranged the gloffy threads, could not but admirc their inimitable beauty; but had no conception of the manner of their formation. Believing filk to be a vegetable production of fome unknown region, fhe night amure her fancy by forming conjectures concerning the appearance of the parent plant; but natural hiftory was a fcience in which o 


\section{$[16+]$}

little progrefs had then been made, that no object belonging to that important branch of human knowledge excited much curiofity. While prefiding over the labours of her attendant nymphs, Agrippina often liftened to fome favourite author, whofe works were read to her by a young female llave inftructed for the purpofe. Nor did this retard the progrefs of her embroiderers, or give any interruption to the bufy fhuttle; it being one of the ineftimable advantages of induftry, that it gives a fimulus to the power of attention, and increafes its capaciry in fuch a degree that what was at firft difficult foon appears to be mechanical. The robes that were manufactured by Agrippi. na's danfels, however they might be orramented by cmbroidery, which was now much in fathion, were of a clofe and folld fabric. It was not till the fucceeding age that they were worn of fo thin a texiure as to attract the notice of the fatirint, and to give juft offence to delicacy. Tafte had 


\section{[ 163 ]}

not as yet been thus far corrupted by licentioufnefs, and confequently modefty was not in the days of Agrippina openly violated in the drefs of thofe who had any wilh to be confidered as virtuous.

A predilection for the principles that had guided the conduct of the venerablematrons of former times, had been early implanted by Antonia in the mind of her daughter-inlaw. Hence, doubtlefs, arofe that lofunefs of fpirit, which difdained to feek for glory in thofe puerile objects to which fo many of her fex directed their ambition. The praife of excelling in beauty, wit, elegance, or learning, was to her not fufficiently gratifying, unlefs fentiments of refpect and efteem were mingled with thofe of admiration.

As the fphere of her duties enlarged, her anxiety to fulfill them increafed in an equal proportion; and as of all the duties to which the was now called, the care and infruction of her children appeared the moft important, it may be believed that the appli-

ed with 


\section{[ 166 ]}

ed with affiduity to the delightful tak. In an affair of fuch moment Agrippina was too wife to be guided by the caprice of falhion. Confidering that plan of education which had produced the greateft and the wifeft men as moft worthy to be adopted, the endeavoured to follow the method that had been purfued in former times. In thofe times, the firft words lifped by the infant tongue had been to the Roman ladies a fignal for commencing the labour of inftruction. Senfible of the advantages of a dittinct articulation, they wifely endeavoured, while the organs of fpeech were flexible, to form them to the pronunciation of every difficult found. By this attention alone it is that children can acquire fuch a command of thofe organs, as is not only effential to eloquence, but highly ufeful in beftowing a facility in the acquircment of every foreign language. From the time that a child could fpeak, no inaccuracy of expreffion was permitted to pafs unnoticed; 


\section{[ 167 ]}

and that they might be enabled thus to lay a foundation for that pre-eminence in the art of oratory, which was a primary object of ambition, ladies of rank affiduoufly culivated the ftudy of their native language. They learned to fpeak with peculiar purity and elegance, and valued themfelves upon this accomplithment, as one that could be rendered uieful to their offspring.

No fooner did it become fathionable to confign the tender period of infuncy to the care of flaves and mercenaries, than oratory declined: nor was it oratory alone that fuffered by this pernicious change, fince to the fame caufe maly fairly be attributed the decline of tante.

To render the mind fufceptible of the emotions of fublimity or beauty, is not a takk to be performed by the vulgar. To perfons of this defcription the rules of criticifm may indeed be known, and by pedants they may be applied with great fagaiety; 


\section{[ 168 ]}

gacity; but to feel, to admire, and to enjoy excellence of every kind and fpecies, is a privilege that not " all the learning of the fchools" can beftow on a coarfe or vulgar mind.

In fixing the affociations by which this fenfibility may in fome refpects be faid to be created, the virtuous and well-educated mother poffeffed fo many advantages over the fervile or mercenary preceptor, that we cannot be furprifed at her fuperior fuccefs. To the inftructions of Cornelia hiftorians have attributed the eloquence of the Gracchi; and it was from Atia that Auguftus acknowledged having derived thofe mental accomplifhments which en. deared him to the Roman people. Nor did the firt and greateft characters of the Roman world fcruple to confe's fimilar obligations to the virtuous matrons fror. whom they derived their birth.

Women fo capable of infructing their fons muft have made no fmall progrefs in 


\section{[ 169 ]}

tafte, knowledge, and literature. They were in fact highly accomplifhed: and as all their accomplifhments tended to fome ufeful purpofe, they were unaccompanied by vanity.

Greek, the only language befides their own which the Romans thought worthy their attention, was affiduoufly cultivated by every perfon of liberal education. Agrippina both wrote and converfed in the Greek tongue with facility and elegance; and it is probable, that it was from her that her children received their firft inftructions in this as in other branches of knowledge. What tafte the lad in mufic cannot now be afcertained; but the notions of propricty that were ftill prevalent, left the ambition of excelling as mufical performers to their Greek nlaves. Ladies, however fond of mufic, were content to liften; nor did it occur to them, that any glory was to be acquired by rivalling in their art thofe public performers who were 


\section{[ 170 ]}

often the mott depraved and worthlefs of the human race.

Compared to the depravity of after-times, Rome was in the days of Auguftus virtuous. To the cotemporaries of Agrippina, the difgufting defcription of the profligacy of female manners, given by the fatirit of a fucceeding age, was by no means applicable. Hany were indeed vicious, but as few had yet arrived at that pitch of iniquity as openly to glory in their fhame, it is but reafonable to prefume, that the numbers were on the fite of virtue. We fhall have the greater reafon to acquiefce in this conclufion, from the refpect that was as yet paid to the female character. And it will be obferved by every attentive reader of Roman hiftory, that it was not till men were no longer indebted to maternal inftruction, that they relinquifhed thofe fentiments of refpect for the fex, which few who have cwed much 


\section{[ 171$]$}

mental improvement to a muther's care, have ever failed to feel.

The character of Antonia bad been too much venerated by her fon, to permit him to entertain that contempt for the female mind, which, by removing every idea of equality, frequently renders the hymeneal chain fo galling. He did not confider Agrippina in the light of an inferior an irrational being, incapable of entering into his fentiments, and unworthy of his confidence and friendfhip. He knew that it was not the honour of tharing in her hufband's ftudies, nor the confcioufnefs of being the chofen companion of his ferious hours, that would lead her to neglect the peculiar duties of her fituation, or to go beyond her fphere. The conduet of Agrippina did honour to her huband's difcernment, and rewarded his tendernefs. By her active mind evcry hour was occupied by its appropriate duties, and of thefe the improvement of her underfanding was neither laft nor leaft.

Einbucd 


\section{[ $\quad 170]$}

Embued from her earlieft years with a taite for literature, fhe delighted to liften to the converfations that were held at her hufband's table by the moft learned men of the age. Supper, the favourite repaft of the Romans, and the only meal at which the family regularly affembled, commenced rather earlier than the modern hour of dinner ; and fometimes lafted till the evening was far advanced. But the time fpent at table was not loft. It was then that Agrippina had the opportunity of hearing fuch difcuffions on every interefting fubject, as ftrengthened her underftanding, and improved her tafte.

Gluttony, the vice of the bafe and degenerate, muft ever be held in abhorrence by fuperior minds. It was for the pleafure of fociety, more than for the luxury of the table, that the friends of Germanicus rejoiced in an invitation to his hofpitable board. Both in the town and countryhoufes of the Romans the apartment al- 


\section{[ 173 ]}

lotted to the focial meal was fituated in the upper part of the houfe, a circumftance neceflary, in the firft inftance, for fecuring the enjoyment of quiet, and advantageous in the fecond, by affording to the vifitors at the rural villa the opportunity of viewing without fatigue the beauties of its profpeits. The focial repaft was in fome refpects confidered as a facred rite. The table was confecrated by the images of the houfhold gods, in whofe prefence it would in ancient times have been deemed indecorous to utter a word inconfiftent with purity and virtue. Thefe deities were deemed the guardians of the ftranger, and became fecurities for his protection and the rites of hofpitality. *

The ideas of reverence that were thus connected with the focial board, rendered the time of meals the moft favourable feafon for difcufing the moit ferious topics. Affociations fo deeply fixed could not be 


\section{$\left[\begin{array}{lll}174 & {[}\end{array}\right]$}

eafly changed; and accordingly we find, that even after luxury had corrupted all the inltitutions of the primitive ages, the cuftom of having a reader to entertain the company during fupper with the works of fome favourite author was ftill obferved. At the conclufion of the meal thefe well-known compofitions gave place to thofe of later date. As indolence and inarity had not yet become the characteriftics of a fine gentleman, moft of thofe who had any ambicion to be diftinguifhed eitherat the bar or in the fenate, could boaft of fome literary production worthy the attention of their friends. Thefe effufions of genius, whether in profe or verfe, it was cuitomury for the author to read to a felect audience previous to publication; that thus having it in his power to profit by the obfervations of friends, on whofe tafte and judgment he could rely, he might be fortified againt the cavils of meaner critics.*

* Yotc R. 


\section{[ 175 ]}

As writing was not then a trade, fame was the generous object of the author's ambition; and as critirifm was paid for in the fame unfubftantial coin as all other efforts of literary tafte, and as it moreover required intellect of the higheft order, and information of the moft exienfive and multifarious kind, few authors engaged in it, that were not perfectly qualifed for the un kertaking. Envy munt inceed in all ages have equally hated the fuccers that attended mert, and ill-nature mut have been then, as in after-times, delighted wich every opportmaty of detraction: but the criticinis of malignity have not been the uglit worily of prefervation; they have perifed wich the paffions that rroduced them, nor can we regret that it is only thole of a more ufeful and gencrous nature that have ofcared the wreck of time.

The cuftom above alluded to, of reahiry aloul the compofitions of the clofet in the iralence of a numerous andence, is utterly 


\section{[ 176 ]}

repugnant to our ideas of delicacy, and indeed feems incompatible with that fenfibility which is fo generally found connected with genius. But to our refined notions of delicacy the Romans were entirely ftrangers. No manwas afhamed of praifing himfelf, or of openly foliciting the applaufe of others; and as the approbation of perfons of approved tafte was fought after with an avidity, of which we can farcely form any conception, we may believe that Agrippina was often called to liften to the literary procuctions of her friends.

Germanicus cultivated a tafte for poetry, and wrore fome tragedies in the Greek language, which are fipcken of as excellent. THe canot now pronounce upon their merits, but they are a proof that his leifure hours were devoted to the elegant gratif:cations of a fuperior mind. Nor lid postry alone engrols the attention of this accomplithed prince. Learned in the laws of his country, and diftinguithed as an orator, he exerted 


\section{$\left[\begin{array}{ll}177\end{array}\right]$}

exerted his talents and his cloquence in the caufe of truth and virtue. Even after he had arrived at the dignity of conful, he appeared at the forum as the fupporter of injured innocence. At the bar, or in the fenate, whether the interefts of the public or of individaals became the fubject of ifcutfion, he zealouly efpoufed the caufe of juftice and humanity. To defend the weak from the oppreflion of the mighty, to bring guilt to punifhment, and to refcue inocence from the fnares of the deitroyer, were objects worthy of Germanicus. For thefe noble purpofes he often exchanged the confular robe for the pleader's gown; and fuch was the high opinion formed of his character, and fo far did the fame of his generofity extend, that his patronage and protection were afliduoufly fought after not only by the towns of Italy but even by foreign fates.

Agrippina thewed upon all occafions fuch a lively intereft in her hurband's fame, that vol. I.

the 
The could not but exult in every proof of his increafing and far-extended popularity. A cautious prudence would have dićated :eferve in the expreflionof thefe fentiments; but cautious prudence was not the characteriftic of lgrippina. She gloried in mortifying Livia, by exaggeraring every proof of public favour thewed to Germanicus. She delighted in convincing her, that Germanicus was the favourite of the people; and that Toerius. however favoured by Auguntus, was ftill the cbject of public averion and contempt.

By this inprudence Agrippina, while the neither added to her huband's reputation, nor her own happineis, increafed the hatred which r...'d in the bofom of her ftep-mother, and arakened the fullen jealoufy of Tiberius. It is thus, alas! that ardent minds, by rafhly yieluing to the impulfe of the moment, fis frequently become accefliry to their own misfurtunes!

CIAP. 


\title{
$\left[\begin{array}{lll}179 & ]\end{array}\right]$
}

\section{CHAPTER VII.}

Ifarriage of Drusus.-P'ublic Amusements. - Death of Caius.-Tinerius and Germanicus sent to quell the lievolt in Dalmatia.-Their Return.-Defeat of Varus.-Agrippina accompanies her IIusband to Germany.-Returns to Rome. - Birth of Caligula.-Second Expedition into Germany.-Death of AUG Us. TUs.-Murderof AgrippaPosthumU.

\author{
$=$ \\ FROM A.D. 9 , TO A.D. 14 ,
}

YOWEVER they might be difpofed L 1 to relifh the pleafures of retirement, it was not pufflible for Germanicus and Agrippina to tafte often of its fweets. Time, that ineftimable talent which thofe who fill a private ftation bave it in their power to fpend 


\section{$\left[\begin{array}{lll}150 & ]\end{array}\right.$}

fpend as inclination prompts, comes burthened with a thoufand taxes to the envied great, who frequently livelefs to themfelves than to the world. Of thefe facrifices of time, the conftant attendance at public fpectacles, which, as a mark of refpect for the people, was numbered among the indifpenfable duties of a Roman magiftrate, may appear to us as the moft painful. But we are not to judge of their feclings by our own. The love of amufement had degenerated into a pafion, from the influence of which few were now exempted. This paffion it had been the policy of Auguftus to cherith, and of fuch importance did he confider the gratification of the public tafte, that in the hour of death he mentioned ir as the glory of his reign, that he had feven and forty tinies prefented the people with games, cither upon his orrn account, or on the account of abfe:t maziftuates.

Upon one occafion, however, he was made to feel, that it was not by tuming the 


\section{[ 181 ]}

attention of the populace to frivolous objects, that he could at all times fecure to himfelf tranq:illity. The difgrace of a favourite performer was deemed an affair of fuch ferious importance, as to throw all Rome into a ferment: and thofe degenerate Romane, who beheld with apathy every encroachment made uron the liverlies of the peorle, could not with parience fubmit to the de. ree which deprived them of a wort'ier individual, who contributed to their amutement. The enperor was in this inftance obliged to yic!d. The banifhed actor was reralled, ind received by the people with fhouts and acclamations, fuch as had formerly welcomed the heroes who had thed thei blood in defence of the liberties of Rome.

The conftant attendance of Auguftus at every public exhibition was not only dictated by policy but inclination. $H_{1}$ was, in fart, fond of the amurements of the populace; and in gratifying the tafte of the people 


\section{[ 132$]$}

people he gratified his own. Nor can we fuppofe that Agrippina was endowed with fentiments of delicacy, that were unknown the age in which fhe lived. Nor is it probable, that in accompanying the rett of the imperial family to the amufements of the arena, the circus, or the theatre, that fhe ever once refiected with any degrec of horror on the nature of the fpectacles that were exhibited.

From regard to decency, Augufus had prohibited the female part of the audience from taking their feats in the circus or amphitheatre, till afier the performance of the wreftlers. But this was the only part of the entertainment from which they were excluded; and to make amends for the mortification, they were permitted freely to indulge their curiofity in behoiding the murder of gladiators, and the ferocious conflict of wild beats. Nor were the amufements of the theatre lefs objection. able; for the plays and pantomimes that were there performed, are faid by refpect 


\section{[ 183 ]}

able writers, to have been too grofs to be defcribed.

The pantomimes were introduced by Auguftus, who, though certainly intent upon the reformation of public morals, piqued himfelf upon having added thefe indecent fpectacles to the number of popular an ufenents; a c rt.in proof, that the confcquences of polluting the imasination had never attracted the attention of the pagan world.

To preferve, amid fuch numerous fources of corruption, a fleady regard for virtue, and manners unblemifhed by any impro. priety, was no ordmary merit. The character of Agrippina will rife in our efteem, according as we are capable of eftimating the temptations by which the was furrounded. Nor can the licentioufuefs of the times be more forcibly difplayed, than by the unbounded applaufe beftowed upun her conduct; fince it was by comparing it with that of others, that her cotemporaries 


\section{[ $15+]$}

muft have formed their opinion of its un common merit. To be faithful to fuch a hufband as Germanicus, appears not to us in the light of an extraordinary effort of female virtue; but the chafte decorum of Agrippina is always mentioned in terms of fuch ligh appotation by the Roman writers, as may induce us to conclude, that they were not acquainted with many fimilar inftances of conjugal fidelity.

About this time Livilla, fiter of Germa. nicus, and widow of the young Cxfar, was married to Drufus the fon of Tiberius. This young man appears in every refpect, but the love of wine, to have been the very oppofite of his father. His temper was open, his heart generous and fincere. Affectionately attached to Germanicus, he rejoiced in the double tie that now unitcd them; and had the difpofinions of Liv that borne any refemblance to thofe of her brother, the happinefs of Druns had been compleat. 


\section{[ 185 ]}

In the midn of the rejoicings at thefe nuptials, the felicity of Germanicus and Agrippina was incmented by a domefic forrow, in which all their frimds partook, nor " cen the the hard heart of Liva

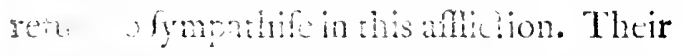
yen: If fon, a chitu of uncommon beauty, nos: cled away by fudden death: and fo P.t.h h... the infantine graces of the lowiy troy codared him to his family, the lis his was lamented with all the fincery andef. In honour to the memory of this captivating child, his effigy, in the churate: of Cupid, was fet up by Livia in : c comple of Venus, for the adoration of the populace; and Auguftus had anothe $\mathrm{r}$ of admirable workmanthip placed in l.t bed chant: r, which he is faid by Suetonitus to have limed as often as he entered the arartment.

While Arrina was indulging that melanchoiy which was naturally occafionca by the lofs the had fuftained, the public 


\section{$\left[\begin{array}{ll}186\end{array}\right]$}

mind was agitated by a variety of events, which altemately called forth the oppofite emotions of grief and joy. The fatisfaction occafioned bythe fuccefs of Tiberius in Iliyricum was counterbalanced by the dread of a general revolt of the concuered provinces from the Danube to the Rhine. A few words dropped by Auguftu, importing the pofibility of the barbarians reaching Rcme by a march of ten days, fpread a general alurm. The apprehenfiun of danger, however caufelefs, gave a facility to the preparations for war, which were carried on with fuch vigour, that the new levies were foon in a condition to follow Tiberius and Germanicus to the field.

As Dalmatia, which had been invaded by the barbarians, was the immediate fcene of action, the emperor thought proper to fix his refidence during the campaign at Arimirium, a convenient fituation for receiving the earlief intellizence from the armies. Thither Agrippina with her family accompanicd 


\section{$\left[\begin{array}{ll}189 & ]\end{array}\right.$}

panied him ane hemained, until the joyful ti a victoryobtained by Germanend dichet the doud that hung over the poblicmod, ant relieved iser from her own peruicur burtlen of ansicty.

The fnecet of Germanicus terminated the war i. Batmotia, where the fubued barbanas gars refund the Roman yoke; and liberias hising whin the div fion under his command obtamed a viktory no lefs compleat, both generals came over to Italy, where on his fur. ing the happy Agrippina joined her victorious lord.

The heart is purlaps never fo fenfible of Ihappinefs, as after a thort feparation from the object of its afection. It that feparation has been attenied wh peculiar circumftances of ciitrefs or danger, every mifery that has been experienced, tends by the force of contrat to in reafe the cmotions of elight, and gives to the pleam Sure of re-union an inexpreflible degree of tendernef. Such were the feelings of

Agrippina 


\section{[ 188 ]}

Agrippina on the fafe return of her amiable huband; nor will it detract from the fincerity of her conjugal affection, to fup. pore that her delight was augmented by the additional luftre which was now fhed on the rame of Cermanicus. Fondly exulting in this accefion of glory, the anicipated the honour of the triumph, which had been decreed to him, in conjunction with Tiberius, by the fenate and people; but before the generals had reached the gates of Rome, the news of a difaftrous event had changed the afpect of affairs, ard converted the public joy into the depth of forrow.

While in Dalmatia every thing had yielded to the Roman arms, the legions on the Rhine were experiencing one of the moft humiliating defeats that had ever ftained the page of Roman glory. The putlic rejoicings inftantly ceafed, and, with all the fervour of popular fentiment, the fong of triumph was exchanged for the groan of defpair. At fuch a moment it would 


\section{[ 189 ]}

would have been improper for the conquerors to have availed themfelves of the decree of the fenate. Refpeet for the feelings of the public induced them to defer the honour, and to enter Rome in a private namner, with no other mark of diflinction than the triumphal robes.* Their fervices were however rewarded by an honourable reception. The rafhnefs and misfortunes of the flaughtered Varus, being put in contraft with their prudence and fuccefs, ferved to fiwell the tide of popular applaufe; and as the repulfive manners of Tiberius checked every fympa hetic emotion, Germanicus appearced the delight of every eye, and the, darling of ercry heart. He received the congratulations of all with unaffected affability; and exprefed his ferife of the public misfortune with a fimplicity that left no donbt of the fincerity of his concern. He found all Rone in mourning, for few were the familics who had

* Notes.

Inot 


\section{[ 190 ]}

not in the army of Varus fome dear riclion tive whofe lof they now deplored.

The death of twice as many thoufands of brave men, had thcir death anfwered the purpoles of his ambition, Augutus would have contemplated wihou emo. tion; but the wound that was inflicted on his pride by the triumph of the barbarians agonifed his foul. Refuling all confolation, his mind perpetually dwelt upon a misfortune which he coifnered as an indelible ftain upon his reign. In the fpirit of fupertition, he addreffed himelf to Jupiter, making a folemn vow to celcbrate the great games to his honour, "if be sould be pleafel to rccoicr the fate from its pre. fout finction," "and in the anguith of defpair, he was frequently feen to knock his head againit the wall, crying cut, "(Buirtillius Varris, give me hack my legrons!"

To retrieve the afines of Germany, no. thing appeared fo necefiury as the prefence 


\section{[ 191 ]}

of Tiberius and Germanicus, who, at the head of a gallant army, were deftined to punith the audacity of thofe who had dared to retort a part of the injuries they had received on the inftruments of their ruin.

Could our German anceftors have boanted of an hiftorian capable of tranfmitting the actions of his nation to pofterity, the pride and infolence which the Romans afribed to the gallant ftruggle of a warlike people, would have been denominated fpirit and virtue. But that fpirit which afpires to freedom, was, in the enemies of Rome, a crime of the higheft magnitude, and as fuch was now to be chaftifed by the adopted fon of Auguftus at the head of his victo. rious legions.

Agrippina was permitted to obey the impulfe of her affection in following her hurband to the fcene of danger and of glory. In the courfe of her long journey, fhe was, we may be affured, accommodated as became a princefs of her high rank: though 


\section{[ 19@]}

though were we to appreciate her travcle ling accommodations by our own notions of comfort, we fhould perhaps wonder how a lady brought up in all the delicacy of a court could bear the fatigues and hardhips to which fhe mutt inevitably have been expofed.

Her travelling chariot, however it might be carved and gilded, was, from the want of frings, no eafter than at common cett. The Roman roads were inded ssceilent, and extended through cues country to which the Romans had pencrated; but after quitting Italy, where the thickly fattered vilias of the Roman and protincial nobility offered a curdidiception at erery ftage, a tent was probably the only fineler of Agrippina during the greateft part of her route.

The wife of Gomancus was not to be appalled by puny crits. In the performance of duty, fixe would lave forned the idea of hardhip or danger; but in the pre- 


\section{[ 193 ]}

fence of her beloved hurband thefe ideas were unknown. While fhe hung on his fupporting arm, the Alpine precipice was divefted of all its terrors; and feated by his fide, the rude forefts of Germany, and the fairer fcenes of Gaul, were beheld with equal emotions of delight.

The Romans were fo little curious with regard to the unpolifhed nations who preferred freedom to the enjoyment of luxury, that Agrippina was not prepared by the accuracy of previous defcription for the new fcenes which rofe on her aftonifhed fight. Thofe who have always moved in a narrow fphere, muft neceffarily have few ideas of comparifon; and to fuch every thing that is new or ftrange, appears confequentlywrong; nor does any object afford delight, or any cuftom meet with approbation, in which fome analogy cannot be traced to objects and cuftoms already familiar to the mind. Every one mut have obferved the eagernefs with which thefe

vol. I.

o analogies 


\section{$\left[\begin{array}{lll}194 & 3\end{array}\right.$}

analogies are lought for by thofe who for: the firt time find themitives furrounded by objects that are in a minner ifolated and detaclied from all tieir previous afiociations. Tranfport an Hebridian or a Crecle to the banks of the Thames, and in every verdant lawn or hady grove they will each admire, nor the beauty of the verdure, nor the richnefs of the thade, but fome circumftance which calls to his recollstion the plains or woods of his native illand.

Thus it was with Agriprina in this her tirft vifit to foreign regions. On entering the deep gloom of one of thofe immeaturable forefts which firetched over a valt portion of Germany, the was, in imagination, tranforted to an Italian grove. At every turn of the majeftic Rhine the difovered fome remote refemblince to the muddy Tibur; and in every rude ftone that bad been fet up by the natives with any appeimance of defign, the fow the reprefentative of we of the ancient gods of Rome, In buing thus mithed by 


\section{[ 195$]$}

her previous affociations, Agrippina was by no means fingular. Her countrymen, even thofe of the higheft rank, were not exempt from fimilar abfurdities. Inftead of examining with minute attention the peculiar cuftoms and religious ceremonies of the Germans, a knowledge of which would doubtlefs have explained in a fatisfactory manner much that now appeared difgufting, merely becaufe it was ftrange; they gratified a filly pride, by defpifing whatever they did not underftand. Often indeed were they obliged to confefs the fuperior addrefs and dauntlefs valour of their formidable foes; but ftill they confidered them as beings of an inferior nature; nor once reflekted, how hort a fpace of time had elapfed, fince the Romans were themfelves in a ftate of civilifation no lefs rude. Such an idea of her anceftors would have been too hocking to Agrippina to be permitted to enter her imagination. Though the delighted to dwell on the antiquity of her family, 


\section{[ 196 ]}

family, and piqued herfelf on the long line of her illuftrious anceftors, it did not probably occur to her that every ftep the afcended brought her nearer to barbarifm, and that when the chain was no longer vifible, it was loft mid ruffians and banditti. Upon fuch flender foundations does human vanity ereet its airy trophies!

Tiberius did not forfeit in Germany the character he had acquired in Illyricum, of an excellent general; but as Germanicus was only fecond in command, and as all the merit of the inferior officers were by courtefy attributed to the aufpices of the commander-in-chief, we know not how much his abilities may in the prefent inftance have availed his country. It is therefore unneceffary to fay more than that the campaign terminated with glory to the Romans, and that in the country of the Trevefi, (now Treves) at a village called Ambiatinus, Agrippina was delivered of a fon, who did not long furvive. 


\section{[ 197 ]}

Altarswere in after ages feen at thisplace, denoting by their infcriptions, that they had been raifed in honour of the delivery of Agrippina; and the inhabitants, willing to flatter themifelves that their country had given birth to a Roman emperor, contended that Cdligula was the child then born: but the affertion was refuted, and the child born at Treves proved to have been one of thofe who died in infancy, whofe name has not been recorded.*

Agrippina, by accompanying her hufband into Germany, had efcaped the mortification of witneffing the deferved difgrace of her fifter. Emilius Lepidus was not a man who would tamely fubmit to have his family difhonoured by a wife of illuftrious birth. He difclaimed alliance with infamy, and no fooner difcovered the flagitious conduct of Julia, than he proclaimed his wrongs to Auguftus and to the world. The guilt of Julia was but too eafily made evident; 


\section{[ 198 ]}

and the fame crimes for which her wretched morher was now fuffering an ignominious exile, doomed the daughter to a fimilar punifhment. Trimetus, an ifland in the Adriatic, was fixed on by Auguftus as the place of her confinement; and there for twenty years this once blooming beauty languifhed in folitary wretchednefs, till death, in the forty-firt year of her age, releafed her from a miferable exiftence.

By the time that Agrippina returned to Rome, the name of Julia was forgotten; or if it were ever mentioned, it was only by Auguitus, and then it was loaded with fuch reproachful epithets, as thewed how deeply he felt the wound which her condurt had inflicted on his heart. The character of Agrippina might have borrowed an additional luftre from contrafting it with that of her mother and fifter; but the mifconduct of fuch near relatives creates in the world a fufpicion with regard to the character of the virtuous, and it required in 


\section{[ 199 ]}

Agrippina no ordinary ftrictnefs of decorum to proferve the purity of her's untainted by the breath of calumny, while the reft of her family had given proofs of a difpofition fo depraved.

How much Agrippina condemned the conduct of her tifter was fhewn by the oppofite tenour of her own; but as a fenfe of honour was the higheft motive on which her regard for virtue could be buil, the confidered not the errors of Julia with the horror excited by the idea of crimes. Though the herfelf offered up her vows at the Ahrine of Minerva, the had no right to blame her finter for choofing a patronefs in the Cyprian goddefs. Both were objects of worhip equally legitimate. But however this mode of arguing might have fatisfied Agrippina's confcience, it could not heal the wound which, through her fifter's difgrace, had been given to her pride. She feit the exile of Julia as ignominious to her family, and inwardly refented it, as a new proof 


\section{[ 200 ]}

of the malignant afcendancy of the em. prefs by whofe advice Auguftus had probably been guided. Nor was the fingular in this opinion; nor was it the punifhment alone that was atringuted to Livia, for by all the friends of the Julian family it was pointedly remarked, that no female of that illuftrious houfe had ever trodden the path of infany, but fuch as had becn brought up under her efpecia! are. To her corrupting arts the criminal levity of both the Julia's was attributed; and when confidered as the victims of her malice, they became more the objects of pity than abhorrence. The unrelenting rigour with which their crimes were punifhed, augmented thofe fentiments of compaffion, and raifed a fecret murmur againt the unfeeling feverity of Auguftus.

Agrippina could not be blamed for partaking in fentiments that were fo generally felt: but fhe had not, like others, the confolation of being permitted to exprefs her feelings 


\section{$\left[\begin{array}{lll}2 & 201\end{array}\right]$}

feelings. Even the fatisfaction of fhewing kindnefs to the infant offspring of her loft fitter was prohibited. The child of which Julia had been delivered after her condemnation, ${ }^{*}$ was by the command of Auguftus left to perifh as an outcaft; nor were the two elder children, though there was no doubt of their legitimacy, taken under the royal protection.

While the defcendants of Auguntus were thus banifhed from his prefence, the art of Livia prepared new triumphs for her unworthy fon. The decree which united him with Auguftus in the government of the provinces, as it appeared to fecure to Tiberius the fucceffion of the imperial dignity, gave a death-wound to the hopes of the moft virtuous citizens, who had turned their eyes upon Germanicus as the wellknown friend of liberty and Rome.

Their expectations in his favour had been cherifhed by a variety of circumftances.

* Niote $\mathrm{T}$. 


\section{[ 200 ]}

As the fon of Drufus he had an equal claim with 'Tiberius on the affection of Livia, and by his murrage with Asripnina he became in an equal degree connected with the empero:. Their children were alike defcended from both; the blood of Auguftus and of Livia flowed in their veins; they were the true reprefentatives of the Julian family, nor had Tiberius any right to difpute with them pretenfions fo jufly founded. As the hufband of Azrippina therefore, laying afide all regard to fupe. rior merit, Germanicus appeared to be the natural heir of Auguftus; and with refpect to perfonal character, the emperor himfelf did not feem to think there could be any comparifon. Of his opinion of Tiberius there could be no doubt, as he did not fcruple to repeat in company the obfervation that had been made upon him in his childhood by Gadara, one of his tutors, who emphatically pronounced him "a a compofition of mud mixed with blood." 


\section{[ 203 ]}

He, on the other hand, never failed to fpak of Germanicus in terms of the highelt praife. He faw and admired the noble qualities of his foul, and loved and efteemed him for his virtues. Nor did he difapprove of the affection that was fhewn him by the people. And yet with a perfect knowledge of the characters of both, he chofe Tiberius for his prefent colleague and future fucceffor!

This conduct would appear altogether inexplicable, did not thevanity difplayed by him on other occafions offer a folution to the problem.

Had Germanicus been lefs popular or kefs deferving of popularity, Auguftus would molt probabily have indulged his affection by devclving upon him the fovereign disnity; but his foul was not fufficiently eniarged to contemplate with fatisfaction the confequences of fuch a ftep. He did no: wilh to be outhone by a fuccetion, whofe virtues would have haded the luftre of his

reign? 


\section{[ 204 ]}

reign. He knew how much he thould lore by the comparifon; and indulged the mean gratification which arofe from the affurance, that after his death the Roman world would look back to the period of his reign with regret. " Unhappy Rome!" exclaimed he one day, as Tiberius left his apartment, " Unhappy Rome! that is doomed to the jaws of thisflow, grinding beaft!"* But, notwithftanding the opinion that he entertained of the fullennefs and cruelty of his difpofition, he always appeared to refpect his underftanding, and to confider him as an able ftatefman and moft accomplifhed general.

'To the afpiring mind of Agrippina the conduct of Augultus upon this occafion muft have been mortifying in the extreme: but her unaffuming hufband was fo far from encouraging her ambitious views, that he feemed more folicitous to avoid than to court the dangerous honours of imperial greatnefs. Attached to the form of go- 


\section{$\left[\begin{array}{lll}205 & ]\end{array}\right]$}

vernment under which Rome had rifen to pre-eminence and glory, he bounded his ambition to thofe conftitutional honours, which had been enjoyed by the illuftrious heroes of former times; and having now arrived at the $24^{\text {th }}$ year of his age, he entered upon the confulfhip with the unanimous approbation of his fellow-citizens.

Wherever he appeared, he was hailed by the voice of gratulation, and old and young, rich and poor, vied with each other in the moft lively expreffions of affection and refpect. Agrippina had her full thare of public favour. Independently of what vas due to her as the wife of Germanicus, her own merit had fecured hor a large por. tion of efteem; and fo blind are mortals with regard to futurity, that the birth of 2 fon during the confulate of her hurband was confidered as a certain omen of her future happinefs. To this fon the name of Caius was given, in memory of his de. ceafed brother; and many were the pious 


\section{$\left[\begin{array}{ll}206 & 06\end{array}\right.$}

vows offered to the gods for the preferva: tion of his life; but had the virtuous pa. rents known that that life was to be ftained by every crime that could difgrace humanity, they would with joy have configned him to an early grave! Happy is it for the peace of mortals, that the veil which covers futurity, is too thick for human eyes to penetrate; and that the fmiles of infancy have a natural tendency to infpire the confidence of hope! Agrippina, flattered by the promifing appearance of her children, indulged the fond idea, that through them the virtues as well as the name of Germanicus hould be tranfmitted to late pofterite; and her mother-in-law Antonia, willing to cherifh the fame agreeable illufion, faw in the blooming family of her fon the perpetuity of an honoured race.

After the birth of Caics, eighteen month; of uninterrupted tranquilitity were fpent by Agrippina and Germanicus in Rome and its neighbourhood; but at the conclufion 


\section{$\left[\begin{array}{lll}207 & 0\end{array}\right]$}

of that period, a fhort feparation took place, Grmanicus being oblized to fer of for Germany, where he was to take the fupreme command, while Agrippina was from fome unknown caufe prevented from accompanying him. The obftacle, which mont probably arofe from the ficknefs either of herfelf or children, was no fooner removed, than the faithful Agrippina prepared to follow. Her two elder hoys were left with Antonda; bur the litule Caius was to be the companion of her jourrey. That he had bern on a vifit to Augutus before his departure, will be leen by the following leitcr, which is one of the few that have been priferved.

\section{Letter of Augustus to AGRIPHIS.}

"Yasterday I gave order for Tizlarius and Afelins to fet out on their joniney towards you, if the gods permit, with your child Caius, upon the fifteenth of the ralcnds 


\section{[ $\begin{array}{ll}208 & \text { ] }\end{array}$}

calends of June. I fend with hin a phyfician of mine, whom, I wrote to Germanicus, he may retain if he pleafe. Fare. well, my dear Agrippina. Take what care you can to come fafe and well to your Germanicus."

Agrippina, after a profperous journey, arrived in fafety on the banks of the Rhine, where the was met by Germanicus, and conducted by him to the camp in the Lower Germany, where the was received with all the demonftrations of refpect and attachment due to her own virtues and to her hurband's character.

As a compliment to her hufband and to the army, the had dreffed her little boy in the uniform of the legions, and held him up thus habited, as they paffed along the ranks, to the delight and admiration of the foldiers, who, obferving on his little foot the calige or foldier's thoe, redoubled their houts of approbation, and fixed, in 


\section{[ 209 ]}

their tranfport, the name of Caligula upon the child, who from henceforth became the darling of the camp.

Awed by Germanicus, the furrounding nations appeared not in the field during the whole of this campaign in any confiderable force. No battle of importance was fought; and the Roman armies, divided in fummer into feparate camps, and in winier ftationed at the moft convenient quarters, were for a length time permitted quietly to purfue thofe occupations to which in peace the troops had ufually been devoted. In this ftate of tranquillity, Agrippina and her hufband would have enjoyed the pleafures afforded by their fituation without alloy, had not every fucceflive meffenger from Rome difturbed their minds by awakening fome fubjecr of anxiety or alarm.

Intelligence tranfmitted by Antonia, thro' the medium of a confidential friend, revived in Agrippina's breaft the long-lont hope of feeing her brother Pofthumus vol. I. 


\section{[ $\begin{array}{ll}210 & \text { ] }\end{array}$}

again reftored to his family and to the world. With no lefs aftonifhment than delight the heard, that Auguftus, without the knowledge of Livia, and in a private manner, accompanied only by Fabius Maximus, and a few felect friends, had gone to the illand of Planafia to vifit the unfortunate youth. The meeting was in the laft degree interefting. No language could exprefs the furprife and joy of the poor devoted Agrippa on finding himfelf in the arms of his grandfather, and affectionately prefled to his aged bofom. No words were uttered in this affecting moment, but the tears that were mutually fhed fpoke more forcibly. Auguftus, free from reftraint, gave a fhort indulgence to the fcelings of paternal tendernefs. What he faid to the young prince in the fhort converfation that followed could not be known, but by the interview he plainly evinced that he was not, as had been fuppored, eltranged from his affection.

Such 


\section{[ 211 ]}

Such was the purport of the communication made by Antonia to her daughter. jn-law, in whofe ardent mind it created emotions fo mixed and various, as in a moment to deftroy all that tranquil refignation, which Germanicushad taught her to affume. The impatience with which fhe waited for the refult of this important event was exceflive, and but for the foothing flattery of hope, could farce have been endured. Giving reins to imagination, fhe fometimes faw her injured brother reinftated in imperial fplendour, and the hated Livia, with her as much hated fon, crouching to the young Cxfar as the deftined mafter of the Roman world. She anticipated to her children the advantages of fuch a protector, to herfelf and to her hufband the pleafure and the fafety of fuch an affured friend.

Thus did the endeavour to divert anxiety, in the rain affurance that the firft meflenger from Rome would bring a confirmation of her wifhes. But alas! the tidings with which 


\section{[ 210$]$}

which all letters were now filled, was of a different complexion. They fpoke of the emperor's languid healtin; of his having avowedly declined all public bufincts, which was now entirely left to the management of Tiberius. They gave an account of parties of pleafure made for his amufement; of the nuticians and comedians who had been honoured by his applaufe; and of the wits or beauties who had attracted his attention. They entered into a minute defcription of fuppers given by livia to felect parties of her favourites, where Augultus amufed himfelf and the company by diftributing jewels and trinkets, which were drawn for by lottery; and gave a de. tail of all the fmart things that were faid upon the occafion. But not one word of Agrippa Pofthumus dia any of the various correfpondents of Germanicus and Agrip. pina prefume to utter. Aftonifhed at their filence on a fubject fo interefting, Agrippina began to fear that Antonia had been impofe: 


\section{[ $\begin{array}{ll}213 & \text { ] }\end{array}$}

impofed upon; and that the interview, which her lively imagination had made the foundation of fo much happinefs, had in reality never taken place. The return of Antonia's confidential fervant put an end to conjecture, and almoft extinguihed every fpark of hope.

With inexpreffible anguih Agrippina lcarned, that whatever were the intentions of Augufus with regard to his grandfon, there was now no doubt of their being fruftrated; fince Livia had becone miftrefs of the fecret, and had already wreaked her yengeance on the head of Fabius Mirsimus, who had been the companion and confidant of the emperor on his vifit to Planafia. This weak and imprudent man had in an unhappy hour divulged the particulars of the myfterious journey to his wife, who, hoping to gain the favour of Livia, treachcroully betrayed the conficience fo rafily repofd in her, and repeated to the emprefs all the had been told by herdoating huband. 


\section{$\left[\begin{array}{lll}214 & 1\end{array}\right]$}

The alarm of Livia was only to be equalled by her rage and indignation. Slic faw the fabric her dextrous hand had reared, and which the had cemented with fo much blood, trembling on the brink of ruin. By the recall of Pofthumus all her deeplaid fchemes in favour of Tiberius would be in a moment rendered abortive. That the emperor, whofe fteps the had fo clofeit guarded, fhould thus elude her vigilance; that the fentiments of natural affection which the had taken fuch unwearied pains to extirpate, fhould ftill exert an influence in his heart; were confiderations fo galling as not to be endured! In the bitternefs of her wrath, the fent a threatening meffage to Naximus, which at once explained to him the perfidy of his wife, and the peri? to which it had expofed him.

Aflamed of his weaknefs, terrified at the refentment of Livia, and dreading the fill jufter indignation of Auguftus; the unhapy man with his own hands puta period 


\section{$\left[\begin{array}{lll}215 & ]\end{array}\right.$}

period to his life! His wife with horror beheld the confequence of her perfidious babbling. In the excefs of defpair, the gave publicity to the whole tranfaction; the wept, the raved, and in the veliemence of forrow, loudly accufed herfelf as the murderefs of her hurband.

What were the feelings of Auguftus upon this occafion, no one could conjecture. But it was fuificiently evident, that he took no further fep towards recalling his grandfon, and that the domination of Livia became every day more compleat.

Agrippina, however flender the thread by which the held her hopes, felt, on feeing it thus rudely broken, all the anguifh of difappointment. Confcious that the language of invective was difpleafing to Germanicus, the endeavoured to fupprefs every expreflion of refentment; but the generous opennefs of her character betrayed the feelings of her foul, and gave an opportunity to the fpies of Livia (for fuch were 


\section{[ 516 ]}

many of Agrippina's pretended friends) to give fuch a report of her difpofition as increafed the malice of her enemy.

Germanicus, though too prudent to encourage his wife in expectations that were fo liable to be fruftrated, had too much tendernefs rudely to danh from her lips the cup of hope. He recalled to her recollection the many infances of affection which the and her brothers had received from their grandfather, and the many proofs of dillike which he had exhibited towards Tiberius, at the very time that he was loading him with public honours. From thefe feeming contradictions in the character of Auguftus, he wifely inferred the impoffibility of forming any decided judgment on his future conduct. He might during his life yield to the afcendancy of Livia, and get refolve at his death to do juftice to the claims of blood. Whatever determination the eniperor might finally adopt, he declared his fixed refolution of bcing 


\section{[ 217 ]}

being guided by his will, and that no allure ment of ambition, no dictate of refentment, thould ever tempt him to depart from the flain path of duty.

by fimilar declarations, Germanicus niccked the officious zeal of his friends, when they ventured to inform him of the wilhes of the people and of the armies in his bchalf. Inftead of liftening to the flatsering aflurances that he had already reigned in the hearts of the Romans, and that the reath of Augutus would open to him a certain afcent to the imperial dignity, he confidered every hint upon the fubject as an affront to his honour; and fuch was the known integrity of his heart, that his fincerity was never queftioned.

Soon was that fincerity put to the fevereft teft. The death of Auguftus was xumoured in the camp, and the name of Germanicus which run in hollow whifpers along the lines, gave fufficient indication of she difpofition of the legions with regard 


\section{[ 218$]$}

to the choice of a fucceffor. The report reached the ears of Germanicus and Agrippina, but as it came in a queftionable fhape, it was by the former treated with contempt.

Agrippina, more credulous, and lefs capable of felf-control, was thrown into a ftate of anxiety and perturbation, which too foon exchanged for the painful certainty of all that her boding heart had feared. Her grandfather was indeed no more; and the cruel fon of Livia had paved his way to the vacant throne by the murder of her brother!

Germanicus would in tendernefs have concealed from her the circumftances of the tragic fcene, but with the heroic firmnefs which characterifed her foul, the fcorned an indulgence given to the fuppofed weaknefs of her fex; and affured her hurband, that the knowledge of the particulars would neither aggravate her refentment, nor prevent her making a facrifice 


\section{[ $\begin{array}{ll}219 & \text { ] }\end{array}$}

of every revengeful feeling to the duty the owed to him and to her children. Germanicus then fubmitted the letters to her perufal, and from them the learned, that Auguftus, on his journey to Rome from Beneventum, (whither he had accompanied Tiberius) was feized with an indifpofition which induced him to ftop at Nola, where his family had formerly refided, and there in the fame houfe, and in the fame chamber where his father had expired, he breathed his lat on the afternoon of the eighteenth of Augut.**

Tiberius, who had been fent for by Livia on the firft appearance of danger, had arrived the evening before, and with feeming grief and real fatisfaction watched the progrefs of the diforder, while in ftolen interviews he concerted with his artful mother the means of keeping the fatal

* In the year of Rome 767, A. D. 14. Auguftus when he did, wanted only a month of compleating this oth year. 


\section{[ $\begin{array}{lll}220 & ]\end{array}$}

event fecret, until he fhould have fecured to himfelf the quiet poffeflion of the imperial" power.

Livia, who fully participated in his anxiety, agreed with Tiberius, that while Agrippa Pofthumus lived, he would prefent an infuperable obftacle to his withes. His prior claims might be powerfully fupported; and if Germanicus declared in lis favour, muft inevitably prevail. Prudence then require? that Tiberius thould provide for his own fafety by the inftant death of his rival. Thus does ambition endeavour to throw the fpecious veil of neceflity over the mot atrocious of crimes!

It was determined, that the moment $A$ - guftus breathed his laft, a centurion, is whom Tiberius conld confide, fhould be difpatched to Planafia to accomplifh the horrid deed. Having affifted in giving the neceffary inftructions to this emiffary, Livia returned to the emperor's chamber, and by the apparent tendernefs of her carefles 


\section{[ 201 ]}

carefles foothed his dying hour. The kifs which fealed his laft adieu was the fignal for the centurion's departure; and till his return Livia continued to fit by the bedfide, as if watching the flumbers of her deareft hufband.

Swiftly did the meflenger of death obey the orders of his mafter. On reaching Planafia, he inftantly fought the young prince, whom he found in a folitary walk, where he was probably amufing his lonely hours with the lively hope of happinefs which his grandfather's vifit had kindled in his breaft. By the fudden affault of the centurion his hopes were in an inftant converted to defpair. But courage was the confequence of defperaiion. Tho' unarmed, he did not eafily yield, and by the ftoutnefs of his refiftance, made the conteft for fome time doubtful. At length the ruffian prevailed, and themangled corfe of the wretched Pofthumus was committed to the waves.

In anxious expectation 'Tiberius waited the return of the affafin; but no fooner 


\section{[ 222 ]}

was he informed by the wretch that his orders had been duly executed, than wit: the refined diflimulation peculiar to himfelf, he affumed an air of ftern difpleafure, told the fellow "be bad given no fuch or. ders, and that for what be had donc be mus anfwer to the fenate." *

Such was the purport of the intelligence received from the friends of Agrippina and Germanicus. Many minute circumftances were added, which tended to aggravate the wounded feelings of Agrippina, and to throw a blacker thade on the guilt of Livia and her fon.

The generous foul of Germanicus revolted with horror from the idea of his near affinity to thore who had thus ftained their hands in the blood of the innocent; but the claims which Tiberius had upon his duty and allegiance appeared in his eyes too facred to be cancelled. Allegiance to Tiberius had not indeed as yet becomeftrictly 


\section{[ 228 ]}

due; but in becoming his fon by adoption, Germanicus had bound himfelf to the performance of every filial duty; and fo nicely delicate were his notions of honour and integrity, that he confidered himfelf no lefs engaged to the performance of what his promifes implied, than to what they fpecified. Obedience to the laws was however, in the opinion of Germanicus, the primary duty of a Roman citizen. He therefore refolved to wait with patience for the determination of the fenate, and guided by its decree, to act as the voice of his country fhould appear to dictate. 
$\left[\begin{array}{lll}2 & 24\end{array}\right]$

\section{CHAP. VIII.}

Fears of Trantus.-Loyalty of GermaNICUS.-AgRIPPINA accompanics him into Gaul.-Mutiny of the Legious.Heroism of A g r I P INA.-At the Request of GERMANICUS, she retires to Ubiortum Oppidum.

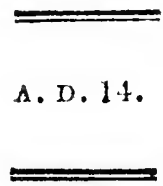

TIBERIUS as yet farcely dared to flat1 ter bimfelf with the quiet poffeffion of imperial power. He could not believe that Germanicus was lefs ambitious than himfelf, nor that a prince who had the voice of the people, and the command of powerful armies, would tamely relinquifh the glorious prize which circumftances had placed within his reach. With cautious

Ateps 


\section{$\left[\begin{array}{lll}2 & 295 & ]\end{array}\right]$}

iteps, therefore, and under the mark of neceflity, he proceeded to take the direction of public affairs. At Rome, though the wilhes of the people were in favour of Germanicus, they were ftifled by the dread of the tribunitian power which was held by Tiberius; who, while he pretended to be utterly averfe from affuming the imperial dignity, had taken care to feize on its moft important prerogatives. But though all now wore the appearance of fubmiftion, he was confcious that even thofe who incd been the moft forward to teftify their loyalty to the nominated fucceffor of $\mathrm{Au}$ guitus, would be the firlt to fly to the itandard of Germanicus, and to recognife as their fovereign him who already reigned in the hearts of the Roman people.

Difturbed by thefe relections, and rerplexed by the various fohemes of difinulation or treachery which prefented themfelves to his mind, Tiberius feenied to hefitate; and fo fucceffully didhe differmble;

$$
\text { VOL.I. }
$$$$
\text { R. }
$$

that 


\section{[ $\left.\begin{array}{ll}296 & 0\end{array}\right]$}

that fome of the fenators were weak enough to believe, that he actually intended to relinquilh all thoughts of the fovereign power. By far the greater number, however, faw throngh the thin difguife, and adopting his own fyltem of deceit, redoubled their folicitations, entreating hirn to aftum. the reigns of government with an earneftncts no lefs fincere than his reluftance. Tiberius, after having fupported his part in the farce with admirable gravity for a fufficient length of time, thought it neceifary to bring it to a conclufion by permitting himfelf to be prevailed upon, and was accordingly invelied with the imperial honours. Neffengers were difpatched to Germanicus to notify the imporrant event, and in the name of the fenate to demand teftimonies of his allegiance to the new emperor. Letters were at the fame time felit from Tiberius to the prince and to the other gencrals, which in the fame language that he had ufed in 


\section{[ [29 ]}

the fenate, declared that " in obedience to the commands of his late father, and in compafion to the republic, he had loaded himielf with the care of the empire, until the fenate hould in mercy relieve him from the intolerable burchen!" .

Whatever contempt Germanicus might feel for the deceit and affectarion diflayed by Tiberius, he did not hefirate a moment concerning the propriety of yielding obedience to the command of the confuls and the fenate. He infantly took the oath of fidelity to 'Tiberius, nor was his refolution Thaken by a perfect knowledge of the fidelity of the army and the wilhes of the people. Cemaniclis knerr, that though thefe were in his favour, a content with Tiberius could not be carried on without a raft effution of human blood. The charms of empire did not appear to him to rery dazzling, as to afford a futicient recomence for ail the cerain evils which would incribly attond on the ambitious exterprife. 


\section{[ 202 ]}

enterprife. And though the power of reftoring the ancient conftitution, and reviving Roman liberty, appeared to his imagination infinitely more glorious than fupreme auhority over willing flaves, he knew that the minds of his countrymen were too much debafed to underftand or to enjoy the bleffungs of civil liberty; and that if their chains were at that noment broken, the only ufe they would make of freedom would be to fubftitute the defpotifm of anarchy for that of an individual.

Thefe fentiments were no doubt ftrengthened in the breaft of Germanicus by thofe principles of loyalty and filial obedience which education had fixed and cherithed in his heart. Nor had Tiberius as yet made fuch a difplay of any vicious propen. fity, as to give an unequivocal affurance that his reign would be fatal to the happinefs of the Roman people. All thofe actions of his life which were moft exceptionable, appeared to Germanicus as the wort: 


\section{[ $\left.\begin{array}{ll}299 & \text { ] }\end{array}\right]$}

work of Livia. It was only in fcenes far removed from her influence that he looked for the real character of Tiberius; and his behaviour in Dalmatia, where he had evinced the qualities of a great commander, prudence, vigilance, and circumfpection, was, in his opinion, a pledge for the propriety of his conduct in a more exalted ftation. Affection for Drufus was another and a very powerful motive for avoid. ing a conteft, which, if it terminated hap. pily for him, muft inevitably be fatal to his brother. With that promptnefs which is the confequence of clear judgment and well-defined principles, Germanicus decided on the part he was now to take, and cheerfully fwore in conform to the will of Aurrutus, by fupporting the authority of the new emperor. Nor did he perform the duty which that oath impofed upon him with lukewarm ind:fference. Senfible that the provinces only wanted a fayourable occafion to throw off the yoke, 


\section{[ 230 ]}

he haftened to fecure their allegiance so the fucceffor of Auguftus; and as this duty neceffuily called him into Gaul, he gladly embraced the opportunity of removing Agrippina to a new fcene, where a charge of objects and of occupation might diffipate the melancholy which oppreffed her heart.

In the noble conduet of Germanicus, Agrippina found a confolation more eflecrual than all the world could offer. Capable of feeling and of eftimating the virtue which was the object of her admiration, fhe belseld with rapture the magnanimity diflayed by her hurband in a juncture when a mind lefs truly great would have yielded to the impulfe of ambition, and have called that ambition glory. In emu. lation of his conduct, the endeavoured to controul her feeliags. She fpole not of Livia; the comptained not of Tiberius; and though the melancholy fate of hor brothers fecretly opprethed her fyirits, the 


\section{[ 2831$]$}

wore compofure in her countenance, and endeavoured as much is poffib e to attain the reality of the checrfuluefs the aflumed.

Germanicus on his arrival in Gaul proclaimed the acieflion of Tiberius, and convened the ftates in order to receive from them the oath of allegiance to the new fovereign While her hufband was engaged in this important bufmefs, Agrippinatmployed herfeff in the inftruction of $h \in \mathrm{r} f \mathrm{n}$, or in receiving vifits of ceremony from the principal inhabitants of the province. In the rovelty of the fcene the could not fail to find amufement, but perhaps its greatert pleafure was derived from a fource lefs pure; and it is but too probable, that the pride of acknomleded fuperionity, and the confcioufnefs of infpiring the mot lively admiration. or the mott profound refpect, were the ideas moft gratifying to the imagination of the Roman princefs.

The Grals, though in comparifon of their German neighbours, or the barba. 


\section{$\left[\begin{array}{ll}232 & ]\end{array}\right]$}

rians of Britain, they deferved the appel. larion of polıfhed, were ftill in a very early ftage of civilifation. They, however, appeared to Agrippina as infinitely more tolerable than the natives of any of the other provinces, and having been converfant with a variety of nations and characters, he was now in fome degree qualified to appreciate their merit. The enjoyment of a pure air and a willing foil gave to the Gauls a degree of fpirit and vivacity, which enabled them to adopt with eafe the more refined manners of their conquerors. Among their chiefs, many affected the Roman drefs; and fome were initiated into the Roman literature, which was always followed by a dereliction of their ancient furertition, and an adierence to that of Rome. But a ftill greater number remained as yet firmly attached to the religion of their fathers, and fent their fons int Britain to be inftructed by the Druids cif itul sistsh, who were beid in peculiar yeseration 


\section{[ 233 ]}

veneration by the Gauls on account of their fuperior wifdom.

The affairs of Gaul were fettled to the fatisfaction of Germanicus ; but farcely had he tafted of repofe, when an exprefs from the army brought the unwelcome tidings of a furious mutiny, which had burft forth with fuch violence as to bid defiance to any influence lefs powerful than that of the commander in chief. The emergency would not admit of delay. Germanicus refolved to fet out upon the inftant: nor would Agrippina be left behind; the promptly and cheerfully obeyed the hafty fummons, determined to thare in every danger to which her hufband might be expofed.

While they haftily purfued their anxious journey, their alarm was increafed by freth intelligence. They learned with horror, that the mutineers had already ftained the camp with Roman blood; that in their frenzy they had maffacred their officers, 


\section{$\left[\begin{array}{lll}234 & 3\end{array}\right]$}

and bad fworn never to fubmit to Tiberius, until he had redrefled their wrongs. Thefe thocking tidings were foon in part confirmed by the appearance of Cafflus Chrerea, a young centurion, who, covered with wounds, had made his efcape from the dreadful fcene, by cutting his way fword in hand through the affailants. Germanicus, after having attentively litened to the detail of all the horrid tranfactions that had taken place in the camp, beftowed merited prailes on the bravery and conduct of the young centurion, who would have confidered the approbation of his generat as an ample recompence for far greater fufierings. The valour of the routh, and the idea of the danger to which he had been recently expofed, excited the fenfibility of Agrippina, who gave the ftricteft charges to her attendants to pay every at. tention in binding up his wounds. Alas! how little did the then imagine, that from the hands of this very man the darling 


\section{[ $\begin{array}{ll}235 & \text { ] }\end{array}$}

child who now finiled fweetly by her fide, was to receive his death!* Blind to futurity, and fully occupied with the interefts of the prefent moment, they proceeded as rapidly as poffible on their anxious journey.

The camp was now in fight, on the outfide of the entrenchments the legions met their general, but infead of the acclamations with which they were wont to hail the return of their beloved chief, they now obferved a gloomy and portentous filence. Confcious guilt and fullen defpair were painted on every countenance; but the awe with which the prefence of $\mathrm{Ger}$ manicus infpired them, reftrined for a time the tumult of pafion, and procured a temporary obedience to authority.

Agrippina was conducted to her tent, while Germanicus, having ordered the men

* It was this Cafius Chrrea, who, when a military tribune, headed the confiricy againtt the emperor Caligula, whom he flew with the affiftance of another confpirator. 


\section{$[480]$}

to furm into their refpective companies, mounted the tribunal, and began a fpeech calculated to recal the infatuated foldiery to a fenfe of their duty. He was for fome time heard with refpefful filence; but when he proceeded to reproach them with their guilt, they firft in hollow murmurs, and then in loud and louder fhouts, proclaimed their wrongs in rindication of their condus, diflaimed allegiance to Tiberius, and with one confent rowed to furport Germanicus with their lives, if he would comply with tive withes of the people, and feize the fovereign power.

No rords can paint the horror of Germanicus, on finding himfelf thus involved in the guilt of rebellion. He inftantly leaped from the tribunal, and as the foldiers oppofed his paffage, drew his fword and pointed it to his heart, refolved to perifh rather than forftit lis lonous. The people rear him wed their utrolt endeavours to 


\section{[ 237 ]}

prevent a catattrophe fo horrid; but the ringleaders of the mutiny, confcious that they were already too deep in guilt to go unpunifhed, had the infolence to defire him to frike. One villain, more daring than the rett, prefented a naked fword, and with an infulting fneer defired the prince to take it, as it was tharper than his own. "This behaviour," fays the hiftorian, " even in the moment of phrenzy, appeared to the folliers an atrocious act. A paufe enfued. The friends of Germanicus feized the opportunity, and conveyed him :o his tent.*

What were the feelings of Agrippina during this tranfiction may be more eafing imagined than defribed. It was imponible to cunceal from her the danger to which Germanicus had beenexpofed. His fintation was full of peril, and hould the army on the Upper Rhine be induced to engage in the revolt, his ruin was ineviable.

* Tacitus,

In 


\section{[ 238 ]}

In fuch circumftances it might have been cxpected from female weaknefs to have added to the perplexity of the moment by unaviling lamentation. Here indeed there was no need of feigning terror, in order to excite her hufband's tendernefs, and diftract his attention. She had only to give way to her feelings, fo effectually to difturb his mind as to render him incapable of taking the fteps that were neceffary for his fafety. But Agrippina, though fuccetible of fear, was fuperior to pufillanimity. She had early been aught, that the fortitude which fuftains with firmuers the prefiure of adverfity, is no unfeminine virtue; and that to be truly amiable is to be at all times rational and wife. Supprefling every cmotion that might have betrayed the ano guifh of apprehenfion, the applanded his firmnefs, encouraged his refolution, and on his return from council liftened with calm. nefs to the account of the plans that had been there refolvcd on, giving her opinion, 


\section{[ 239 ]}

when required, with modefty, but with precifion.

The meafures taken by Germanicus were fuccefsful. The legions, having received from the private finances of their general the full payment of their arrears, and a folemn pronife of redrefs of other grievances, proceeded to winter quarters, while Germanicus haftened to the army on the Upper Rhine, which had larely experienced a fimilar convulfion. Here order was happily re-eftablined, fo that his prefence was not long neceffury; he therefore after a hort ftay proceeded to meet the deputies of the fenate at the winter camp fationed near the Ubian alter.*

The legions quartered at this place had been deeply engaged in the late mutiny. Confcious that their grilt had gone unpunifned, they were eafily induced to belicve that the fenate, inftead of confirming the the pardon granted by their offended ge-

- Where the city of Bon noiv funds. neral, 


\section{[ 240 ]}

neral, had decreed them traitors to their country, and that the deputies were fent with no other intention than to make them examples of a fignal vengeance. Fear gave birth to the credulity by which it was again augmented; and as fear when affociated with confcious guilt is the moft fierce and cruel of the paffions, it is not furprifing that the explofion which now took place, fhou!d have been proportionably dreadful.

The confpiracy though extenfive was fecret. The deputies were received on their arrival at the camp with all proper demonftrations of refpect. Germanicus and Agrippina, having fpent the evening in interefting converfation with their guefts, concerning the friends mot dear to them, revired to reft, unconfcious of the dangers by which they were furrounded. At the ftill hour of midnight they were awakened by the clamours of the furious multitude, who foon with violence broke open the doors of the houfe, and ruihing into 


\section{[ 241$]$}

into the apartment of Germanicus demanded the purple ftandard, which was in the hour of battle the fignal of attack. Germanicus, without means of dcfence, without time for recollection, was forcibly dragged from his bed, and by menaces of inftant death compelled to furrender the ftandard, which they fo violently demanded.

The deputies were now the objects of vengeance to the credulous and enraged multitude. The chief of the embaffy was an old fenator of confular rank, Munatius Plancus, and him they had refolved to confider as their moft determined enemy. Plancus fled to the altar of the gods, for by this facred name was the place diftinguifhed where the ftandards of the legions were depofited. He feebly grafped the eagles, and demanded protection, but in vain. The torrent was too impetuous to be refifted by the barriers of fuperftition, and but for the gallant defence made by a voI. I. 


\section{[ 242$]$}

ftandard-bearer, the unhappy Plancus muft have fallen a facrifice to popular fury.

Germanicus had now again to ftem the tide of treafon and rebellion; and Agrippina again to fuffer all the agonies of apprehenfion, from the danger to which he muft inevitably be expofed. At the dawn of day the faw him depart, for the purpofe of encountering the ftorm, and either ftilling it by his authority or perifhing in the attempt. In folemn filence he advanced to the tribunal, and commanded Plancus to be conducted from his place of refuge. The command was infantly obeyed. The awe-ftruck multitude permitted the object of their refentment to pafs unmolefted to Germanicus, who, having refpectfully placed him by his fide, addreffed the foldiers in a hort remonftrance, calculated to infpire them with remorfe and horror at the enormity of the crime they had fo nearly perpetrated. The men were aftonihed, perhaps terrified, at the forcible reprefentation of 


\section{[ $\left.\begin{array}{lll}243 & 1\end{array}\right]$}

their guilt; but no fymptoms of compunction or repentance appeared. Germanicus, to fhew them that they had forfeited his confidence, committed the ambaffadors to the protection of a detachment of auxiliaries, and difmiffed them from the camp.

On returning to his houfe the prince found a number of his friends, who had hurried thither from all quarters on the firft news of the outrage that had been committed on his perfon. He was immediately befet by prayers and intreaties to fly from a place where mutiny and treafon reigned, and that haftening to the army on the Upper Rhine, he lhould return with a fufficient force to chaftife the delinquents. Germanicus, naturally averfe to meafures of feverity, and indignant at the idea of ruming in fear from his own troops, refufed to liften to them on the fubject; but when they proceeded to fpeak of A grippina, when they reprefented to him the danger so which the might poffibly be expofed, he 


\section{[ 244 ]}

no longer retained the firmnefs which he had bitherto fupported. Obferving his agitation, they proceeded: "Why," faid they, " if you fet no value on your own life, why rifk that of the princefs and your infant fon? The commonwealth demands of you their fafety. They are the property of the ftate-the children of Auguftus-ithe hope of Rome-and their fecurity depends on you." **

Germanicus greatly agitated turned to Agrippina. 'You fee, my Agrippina,' cried he, 'that the opinion of our friends coincides with mine. All that they have now advanced, I have already urged. Perfift not, I befiech you, in refufing to comply with my moft earneft wihh, nor opprefs my heart by denying it the confolation of being affured of your fafety.'

"I thank you, Germanicus, I thank our noble friends," cried Acrippina, indignantly, "for imagining that the defcendant

* Tacitus. 


\section{[ 245 ]}

of Auguftus, the daughter of Vipfanius Agrippa, has fofar degenerated as to fhrink from danger. By what part of my conduct have I deferved a treatment fo injurious? In what inftance have I departed from the character of a Roman matron, that I fhould thus be called on to defert my hurband in the ftorm, and to provide for my own fafety by a daftardly and ignominious flight?"

'No,' replied Germanicus mildly, " no my love. It is not for your own fake, it is for mine, that I conjure you to go. While you remain in this ferte of tumult and diforder, I am truly mifrable, nor can 1 anfwer for the confequence. To manage the unruly paffions of the multitude, when once they have broken the bounds prefcribed by authority, requires the utmofe con wind of temper and of pridence. Shoult any infult be wered to yon, thefe would inftantly be loft. No longer mafter of myfelf, I could not avoid giving winy to 


\section{$\left[\begin{array}{lll}246 & ]\end{array}\right]$}

the fury of refentment, and by fo doing, might involve us both in ruin.'

Agrippina remained inexorable. "You would have me go," faid the to Germanicus reproachfully, " becaufe you can bear with parience the difgrace of being thought unable to protect me. But in my eyes life is an fin precious as to be preferved at the expence of twon, wr; and rather would I with this bant an a period to my exizta ence, than hear it fand, that the wife of Germanicus was obiged to feek a refuge with the barbarians."

At thefe words the prince caught Ca. Jigula in his arms, and prefing him to his bofom, melted into tears. Agrippina, over, come by this prouf of tendernefs, threv Fer ams round his neck, and gate way to thofe emotions which her high firit conla no longer fupprefs. "Yes," cried Cermanicus, embracing ner, " yes, my A gripm pind, it is on pou thethelives, the fafty of our offspring now depend. L me 


\section{[ $\left.\begin{array}{lll}247 & \text { ] }\end{array}\right]$}

adjure "ou by your love for this boy, by your regard for the unborn babe, whofe fite is involved in your decifion, to comply with my requeft. Had no infubordination prevailed, I hould have wihed you to have removed to the neighbouring city of the Ubii, before the period of your confinement; but as things now are, it would in your fituation be madnefs to remail."

Agrippina, no longer able to refift entreaties urged with fo much tendernefs, affented to the propofal, as an inftance of duty and obedience.

No fooner was the determination of Agrippina made known to the fuperior offcers, than all the matrous who had accompanied their huthands to the camp, were with one coris affembled to attend her. The melanctuviy proceffion fooncommenced. The female attendants of the princefs led the way, followed by Agrippina and her infant fon, whom the carried in her arms, bedewing his face with her tears. The wives 


\section{[248]}

wives of the officers according to their rank followed clofely after; and numbers of inferior ftation were driven forth from their hufbands to augment the train. Thefe untutored minds, alarmed at the difconfolate appearance of all around them, caught the contagion of forrow, though hardly knowing what they had to fear, and by their thrieks and lamentations added to the impreffivenefs of the fcene.

The Romans were too confcious of their courage to be afhamed to weep. Germanicus and his friends, while theybeheld the departure of the tender objects of their attacliment, permitted their tears to flow; and fent up their prayers to the gods for the fafery of their wives and children.

Such was the fpectacle that prefentcd itfelf to the aftonifhed legions, as the proceficion moved nowly on through the ftreets of the camp. "The folliers liftened," lays Tacitus, " they came forth from their sents; they ftood aftonined at the fight; 


\section{$\left[\begin{array}{lll}2 & 0 & 4\end{array}\right]$}

and why, they faid, wherefore thofe notes of forrow? What means that mournful fpectacle? A train of noble matrons deferted, left to themfelves, abandoned by all! No centurion, not fo much as a foldier to accompany them! The wife of the general, undiftinguifhed in the crowd, wirhm out a guard, and without the trin of attendants fuited to her rank, fent forth to fcek in a foreign ftate that protection denied her in a Roman camp!",

To thefe reflctions fhame and remorfe fucceeded. Lvery breaft was touched with fympathy, and the fitte of Agrippina in particular made the deepeit impreffion upon every heart.

The fight of Caligula raifed their emotions alnoft to phrenzy. He had ever becn the darling of the foldiers, who boafted of his having been nurfed and educated in the camp. "Yet this child of their affections was now by their frantic folly driven from among them, and his mother, honourcd for 


\section{[ $\left.\begin{array}{lll}250 & \end{array}\right]$}

her virtues as much as for her rank, fhe too mutt fly, fly from the men who had fought and bled under the command of her illufo trious anceftors! Stung to the quick by thefe reflections, the foldiers preffed forward to Agrippina to oppofe her paffage. They knelt, they wept, they entreated her to ftay. They flew in crowds to Germanicus, and implored him to fpare them the mortification of feeing her depart. They befought him to punifh their crimes in any way but this: they fupplicated, they entreatcd, till, when arlength theprince feemed about to break the indignant filence he had long obferved, the half-finifhed fentence died away upon their lips in the engcrners of attention.

"My wife and children are ever dear io me," faid Grermanicus, " but not more fo than my father and the commonwealth. But the emperor will be fafe in his own imperial dignity, and tis commonwealth has other armies to fight her battles, For 


\section{[ 251 ]}

my wife and children, if from their deftruction you could derive additional glory, I could yield them up a facrifice in fuch a caufe; at p:efent I remove them from the rage of fratic men. If horrors are ftill to multiply, let my blood glut your fury. The great gandfon of Augutus, and the daughter-inlaw of Tiberius, need not be left to fill the meafure of your iniquity. Without that horrid cataftrophe, the fcene of guilt may end. But let me ank you, in thele laf days what have you not attempted? What have you left unviolated? By what name thall I now addrefs you? Shall I call you foldiers? foldiers who have dired to benege the bn of your emperor! Can I call you citizins? citizens! who have trampled unicr your feet the authority of the fenate; who arve violated the moft awful fanctions, ever thofe which hoftile fatcs have ever hed in refpect, the rithers of anbifidors, ind the law of nation!"* 


\section{[ [ $25 \%$ ]}

Germanicus proceeded to plint in the ftrongeft colours the atrocity of their con: duct, and by a happy tranfitior to the fate of Varus, endeavoured to concentrate their contending pafflons againft tie common enemy. When he faw that hs cloquence had mate a fenifible impreffon, he thus continued: "May that revenge be ftill referved for the Roman frood; and may the gods withhold from the Belgic ftates, though now they court the opportunity, the valt renown of vindicating the Roman name, and humbling the prid of the German nations! And may thy pirit, adored Augufus! and thine, Drufus, my ever-honoured father! infpire thefe anhappy men, whom I now fee touched with remorfe. May your active energy ble: out the difgrace that fits heavy upon hem, and my the rage of civil difcord difuarge itfelf on the enemies of Rome! And on, my fellowfoldiers, whon I bchold witi altered looks, whofe hearts begin to mel with forrow 


\section{[ $\left.\begin{array}{lll}253 & \text { ] }\end{array}\right]$}

and repentance, if you mean to remain faithful to your prince, and to reftore my wife and children, detach yourfelves at once from the contagion of guilty men, withdraw from the feditious; that act will be a proof of your remorfe, an earneft of returning virtue."

This harangue had the defired effect. The foldiers in a fuppliant tone requefted Germanicus to felect for punifhment thofe whom he confidered as moft guilty, but at the fame time entreated that he would recal his wife and fon. The prince, anxious to have Agrippina removed to a fcene of greater tranquillity than the camp was for fome time likely to exhibit, and having plans in view which muft foon have renewed the pain of parting, would by no means confent to her return; but with regard to Caligula he relented. Meffengers were immediately difpatched to bring him back; and the foldiers, who impatiently waited his appearance, hailed his re-entrance into the camp with fhouts and acclamations. 


\section{[ $25+4]$}

Caligula was too young to underftand the meaning of the uproar ; but it is not improbable, that it made a ftrong impreffion on his tender nerves. How far this inpreffion might influence his future character, it is impofible to determine; but to thofe who affert that fcenes of cruelty have a tendency to produce a manly courage, it may not be fuperfluous to enforce the obfervation, that he who was at once the moft ferocious and unlettered of the Cxfars was early accuftomed to the fight of blood.

No fooner did the influence of Germa. nicus turn the tide of thofe paftions which had raged with fo much fury, than the popular phrenzy took a new direction. the rage of the foldiers was now turued againit thofe who had led them on to mus iny. Singling from anong their ranks thofe who had been foremont in the tumult; they bound them in chains, and bringing them to a fuperior officer, louily demanded 


\section{[ 255$]$}

their inftant execution; each, by the alacrity with which he affifted in the flaughter of his companion, endeavouring to expiate his own thare of guilt. Such are the confequences of ftimulating the paffions of the unrefiecting multitude, in the vain hopes of being able to guide at pleafure the direction of a flame, which, when thoroughly kindled, is far too furious for control, and frequently involves both friend and foe in one promifcuous ruin! 


\section{$\left[\begin{array}{lll}0.56 & 0\end{array}\right]$}

\section{CHAPTER $X$.}

Agrippina proceeds to the City of the Ubii. -Mamers of the Germans.-Entertaimments.-.Martial Dance-Gaming. -Respect for their Female Relations. - A German Wedding.-Thesxelds the quife of Arminus.--Her Adientures.

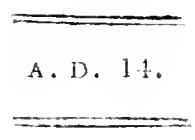

A GRPPINA meanwhile proceeded on 1 her melancholy journey, rendered more irterme by having loft the company of her fon, whofe infantine prattle might have beguiled the heavy hours, and prevented her thoughts from dwelling on fub. jects that were anxious and perplexing. She was, it is true, furrounded by many faitbful 


\section{[ 2.57$]$}

faithful friends; and the nation of the Ubii, on whofe territorics fhe was about to enter, were deroted to her family; fo that for herfelf the had nothing to apprehend. But fhe ftill trembled for her hurband's fifety: her fpirits had not yet recovered from the agitation into which they had been thrown by the late tranfactions, and wherever the caft her cyes, the abfence of Germanicus, like an eaft wind, gave a hardnefs to the outline of every profpect.

No fooner did the inhabitants of Ubiorum Oppidum receive notice of the honour intended them, than they haftened to meet their noble vifitor; and to affure her of a proud and joyful welcome. To them Agrippina was cndeared by ties which the Germans held moft facred. Originally inhabitants of the eaftern fide of the Rhine, the Ubiuns laad incurred the difpleafure of their German neighbours, by their attachment to the Roman caufe. During Caxfur's wars in Gaul they had placed them.

$$
\text { yol. ? }
$$$$
s
$$

felves 


\section{[ 258 ]}

felves under his protection, and by adlicring faithfully to the engagements they had then made, brought upon themfelves the perfecution of the Cattians, and the Suevii; by whom they would have been overpowered, had not Vipfanius Agrippa, at that time commander of the Roman armies, refcued them from deftruction. Conducting them to the weft fide of the river, Agrippa there gave them a territory of fufficient extent, aided them in building their new city, and declared himfelf their patron and protector.

Ardently attached to the memory of their benefactor, the Ubians confidered the honour conferred upon them by the prefence of his daughter as one of the happieft events. Their honeft gratitude appear. ed in every action: répectfully conducting Agrippina and her fuite into their city, (for fo the affemblage of ill-conitructed huts was called) the principal houfe was prebared for her reception, as well as the fhormels 


\section{$\left[\begin{array}{lll}259 & 2\end{array}\right]$}

of the notice would permit, and what was wanting in elegance was abundantly fupplied in good-will.

It was in fituations like thefe that Agrippina fully experienced the advantage of having had her mind formed in early life to habits of fimplicity. Taught to confider the flaves of luxury as under the moft ignominious bondage, the carefully preferved her mind from its dominion; and by frequently fubmitting to voluntary privations, prepared herfelf for encountering with refolution thofe which the viciflitudes of fortune might render inevitable.

To Agrippina and her friends all was new and ftrange. In her progrefs with Germanicus the had indeed often feen the ratives of the country; but the communication with them had till now been flight and diftant. The tight drefs of the men apneared in the eyes of the Roman ladies indelicate and offenfive. That of the women was more graceful. A robe, though not of yery 


\section{[ 260 ]}

very flowing d̀rapery, partially conccaled their fhape, leaving the arms and part of the bofom uncovered. The texture fel. dom varied. It was of coarfe linen, adorned, according to fancy, with purple ftains. "Our wives," faid the chief in prefenting his to the princefs, "our wives are una. dorned crcept with modefty, Their treafure is the affection of their hufbands, and the reverence of their children. You who are a virtuous wife and happy mother will find them worthy your protection!"”

Agrippina, returning a proper compliment, faluted the honourable matrons with great complacency. The feat being now prepared was ferved up according to the manner of the country, every one fitting at a feparate table. The fare would not by a voluptuary have been confidered tolerable. But though the mutton was newly killed and very ill broiled, the curds were excellent, and the wihd apples, not-

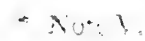

withetandin: 


\section{[ $\left.\begin{array}{lll}261 & 6\end{array}\right]$}

withitanding their acidity, were highly flavoured. Agrippina, though the never drank any thing ftronger than water, had the curiofity to tafte the liquor made from barley, which the had often heard fpoken of as the favourite beverage of the Germans. Wine indeed the Ubians could now boaft of, as the vineyards planted under the aufpices of Agrippa, on the banks of the Rhine, had come to great perfection, and produced abundantly. But ftill many of them from long habit gave a preference to ale, which they drank in fuch quantities as to anfwer all the purpofes of intoxication. The characteriftic virtue of the women afforded fufficient evidence, that inebriety was a vice confined to the other fex; fince excefs is altogcther incompatible with fteady regularity of conduct.

The houfe deftined to Agrippina was, like the others, furrounded with a fmall inclofure, for the Germans confilered being syerlooked by a neighbour as an infringe. 


\section{[ 869$]$}

ment oil freedom, and therefore even in their towns built each houfe apart. The flaves who attended the princefs, were thocked at the homely furniture of her aparment, but the with better fenfe fmiled at their difters, and though the could not help being incommoded by the fmoke, which having no vent filled every part of the houf, the neither gave way to fretfulnefs nor difcontent.

Agrippina was not more furprifed at the infenfibility of the Germans to this inconvenience, than they in their turn were attonithed how the could bear being trou. Wed with the attendance of fuch a nume. rous retinue. This the difcovered by means of one of the daughters of the Ubian chief, to whom as the had conceived at liking, the permitted the liberty of attending her toilette. "Is the lady lame," afked the young barbarian, "that the requires fo much affinance? But if the has lont the ufe of her own limbs, why cannot one per. 


\section{[ 263 ]}

fon reach what the wants? Why torment her with fo many to do fo very little. Alas, that one fo great thould be fo helplefs!"

The pride of the Roman was piqued at thus exciting only pity, where the expected admiration. ' And has your mother then no flaves to attend her perfon?" afked Agrippina.

"O no;" replied the girl, " my mother is too proud to be dependent. Our flaves live in their own houfes, and take care of their own families ; they till the ground, and raife corn, and take care of the vineyards; but they do not come near us, we want none of their affiftance."

Agrippina then difcovered that all the houfehold bufinefs was managed by its miftrefs and her daughters, without the affiftance of fervant or of flave; and that as nothing could be more difgraceful than a flothful performance of thefe neceffary duties, the girls were from infancy brought up to diligence and activity. Indolence 


\section{[ $26 \%]$}

was the cxciufive privilege of the men, whe in time of peace pafed the lugginh hours in lleep or gluttony. The hero who had in the field braved every danger, and whote astive and enterprifing fpirit had fuftained all the evils of fatigue and hunger, and want of reft, with a refolution amounting to inferfibility, funk on his return into liftefsnefs; from which he was only to be roufed by objects that applied to the paftions.

Agrippina did not for fome time fee much of this, as her arrival had created a fufficient degree of intereft to prevent the Ubians from finkinginto torpour. To ferve or to amufe their illuftrious vifitor, was the object of every heart. In every houfe the feaft was fpread, and the ftrangers who poured in from the furrounding country to get a fight of the Roman princefs, were welcomed with a fpirit of hofpitality which Agrippina had never before feen any thing to equal. As dancing was the amufement i. which they took most delight, they naturally 


\section{[ 265 ]}

naturally thought, that by an exhibition of this kind they thould moft highly gratify the Roman ladies, who, they were perfuaded, had never wimefled any fpectacle half fo intereiting. Agrippina cheerfully accepted the invitation, and with her friends and attendants, went at the appointed hour to the place of entertaimment, which was a fpacious lawn in the vicinity of the city. There, on an eminence, a fort of throne had been prepared for her, to which the was conducted by the Ubian chief, who had enough of the Roman langunge to do the office of interpreter. A land of young men immediately made their appearance, armed with frords and javelins, and drefled in thort tunics of white lineil. "Here are fencers!" cried Agrippina on perceiving them, " pray to whom do thefe performers belong?" 'The chief, aftonified at her ignorance, replied, that the young men were all of noble birth, that they were not to fence but to dance, for 


\section{[ 266 ]}

with the Germans dancing was a martial exercife; that in honour to her they were clothed with the garments which they now wore, otherwife it was their ufual cuftom to darce unincumbered by clothes. As he thus fpake, the performance commenced; and Agrippina could not but admire the agility, grace, and elegance, that was difplayed in every movement. The clafhing of fwords feemed at firt to keep time with the mufic, but the combat foon became more fierce; wounds were given and received; and though, from the blood that flowed, many were evidently very ferioufly hurt, none relinquifhed his place, or appeared fenfible to pain, but rather to go through the evolutions of the dance with redoubled animation. Agrippina had been too much accuftomed to the amufements of the amphitheatre, to be flocked by this fpectacle; but could not forbear exprefling to her companions her aftonifhment, that any who were of free birth fhould thus exporic 


\section{[ 267 ]}

expofe themfelves to unneceffary trouble, She however took care to conceal her fentiments from her entertainer, and diftributed prefents of golden chains and bracelets amoug fuch of the performers as had moft diitinguifhed themfelves in the martial dance.

On the following day, as Agrippina was walking through the city, her attention was attracted towards to a young man of uncommonly dignified afpect, who was bound in chuins, and walking with a look of ftern fortitude by the fide of a perfon who eyed him from time to time with an air of feeming exultation. On a nearer approach, fhe recollected having feen both thefe youths in the dance of the preceding evening. The gold chains which the had given to each, were now both worn by him who was leading the other into captivity, and who appeared too much elated by profperity to take notice of any furrounding object. On being ftopped by her interpreter, whom the had ordered to enquire 


\section{[ 066$]$}

enquire into the meaning of thefe extraordinary circumftances, they both lifted up their eyes, and on feeing Agrippina betrayed fymptoms of confufion. Both were covered with bluthes, but while the captive feemed to fhrink from her inquifitive glance, the other, affecting a carelefs air, came forvards, and informed her attendant, that after partaking of the banquet which had been prepared for them the preceding evening, they had, according to the cuftom of their nation, amufed themfelves by gaming; that the young main his companion, after lofing all that he had in the world, had ftaked the gold chain given by him the princefs; and that likewife being loft, he had at length ftaked himfelf! You fee the confequence, added he gaily, he is now my flave, and I an about to fell hin to the higheft bidder.

Agrippina was extremely fhocked at this account, and after a moment's deliberation refolved to fave the imprudent youth 


\section{[ 269 ]}

from the horrors of a fate fo dreadfulo Having learned the price that was fised upon him, fhe defired both the young men to follow her to her houfe, where, with a frowning afpect, the delivered the money into the winner's hand, telling him at the fame time never more to approach her prefence. Mortified and abafhed he flunk away, while his companion, releafed from his fetters, threw himfelf at the fect of his benefactrefs, and exprefled by a flood of tears the feelings of gratitude which overwhelmed his heart.

Agrippina did not fail to give to $\mathrm{Ger}$ manicus a very particular detail of all the circumftances that occurred to her obfervation, In every letter he repeated his injunctions to continue her remarks on the manners of the barbarians, and to ufe all the means in her power to obeain informarion concerning the meaning and origin of fuch cuftoms as appeared to her mofe

$$
\text { Not II ftrunge }
$$




\section{[ 290 ]}

ftrange and unaccountable. But though indefatigable in her enquiries, it was but feldom that the met with fatisfaction. Even in the civilifed world cuftoms are continued long after the circumftances in which they originated, have ceafed to operate, and are forgotten; but to a rude and fimple. people whatever is immemorial appearseter. nal. With regard to what was reported to her of the various fuperftitions of the natives, Agrippina was perhaps fufficient'y credulous; but as the very fituation of the groves in which the principal ceremonies of their religion was performed, was carefully concealed, it is not to be fuppofed that the accounts they gave of their facred rites twas to be depended on as gemuinc.

No circumftance in the behaviour of the Germans appeared to the polite Romans fo entircly unaccountable, as their high refpect for the fofter fex. Augunus, obferving that the women were confitered as their deareft pledrges, and that the idca 


\section{[ 271 ]}

of their being led into captivity was infupportable, demanded female hoftages from the conquered tribes, as the moft undoubted of all fecurities. The event did honour to his penetration; as they who had never confidered their male hoftages as of any confequence, were never known to break a treaty when female honour was concerned in its prefervation. With thefe facts Germanicus was well acquainted. $\mathrm{He}$ had likewife winnefled the efferts of the ardour infpired in the barbarians by the prefence of thefe beloved objects of affection in many an engagement, where the men were urged on to the cruel conflitet by the fhouts of approbation fent up by their wives and daughters who furrounded the the ficld. He had feen the combat at their inftance of renewed, and by their interference the glo:y of vistory fratched from the Roman arnis. But he knew not by what means the German women had obtained fo great an afcendancy, and would 


\section{[ $\left.\begin{array}{lll}272 & ]\end{array}\right]$}

not lofe an opportunity fo favelirable as the prefent for having his curiofity gratified.

The obfervations which Agrippina made, led (or might have led) her to conclude, that the efteem and refpect in which the German women were held by their male relations, mas as much the caufe as the confequence of their fuperior merit. Confcious of having a character to fupport, they were impelled by the moft generous motives to the exercife of all the virtues on which their nation fet the higheft value. In war they accompanied their hubands to the field, and after the battle, it was upon them that the care of the wounded cntirely devolved. They were the only furgeons, and by their fkill in the art of healing fupported that charaster of fuperior wifiom, which they had imperceptibly acquired. How it came to be acquired will be cafily accounted for, when we reflect, that in the intervals of peace, while the other kx were engaged in guming, drinking, and quarrelling, or in 


\section{[ $\begin{array}{ll}273 & ]\end{array}$}

the indulgence of floth, no lefs injurious to the mental powers, they were in their domeftic avocations accuftomed to the perpetual exercife of judgment. Hence, when queftions of importance came to be difcuffed, they who were neither blinded by the fury of the paffions nor the fumes of intoxication, had an evident advantage over their impaffioned lords; and were frequently enabled by their fagacity and difcernment to penetrate into the probable confequence of events, in a way that to minds incapable of reflection appeared altogether extraordinary. The Germans had the good fenfe not to defpife the judicious counfels of their female friends; but to refcue the pride of fex from the mortification of acknowledged inferiority, they afcribed the wifdom of which they availed themfelves to the infpiration of the gods! Whether it was the old women only who were believed to be thus infpired, or whe. ther illumination was particularly attributed 


\section{[ $2 \% 4]$}

to the young and beautiful, could not perhaps be eafily afcertained; but neither in youth nor age did the German females difgrace the facred character with which they were thus invefted.

Agrippina, after her arrival at Ubiorum, was invited to the celebration of a grand feaft, given by one of the principal chiefs in honour of his daughter's nuptials. A few days previous to the folemnity the went with a friend to pay a vifit to the intended bride. They were received with the utmolt refpest by the mother of the family and her daughters, who, contrary to the expectation of the Roman ladies, were neither embarraffed by their prefence, nor relustant to fatisfy their curiofity. In anfwer to the queries concerning the fortune of the bride, they were given to underftand that marriages in Germany were not contracted from mercenary motives. "My daughter," faid the mother of the bride, "has been fought by many chiefs, but flie has preferred 


\section{[ $\begin{array}{lll}975 & ]\end{array}$}

preferred the fon of our friend. The youth has proved himfelf deferving of her love, for in fingle combat he has flain three of the mont valiant of the Suevii. She in the Jaft war accompanied the other maidens to behold the battle, each refolved, fhould the enemy prove viatorious, to die by her own hand, rather than fubmit to the conquerors, for never has any of our race furvived their honour. Her gallani lover was crowned with glory, but he was deeply wounded in the bloody fray. Had the nor been there, he mut have perifhed. She flew like lightning to the fpot where he lay gafping with fatigue and agony; the bound up lits iwounds, the adminiftered cordials to revive his foul, and affifted by the damfels her companions in raifing a fhed of green boughs to keep out the fcorching rays of the fun, the attended him by night and day till his recovery was completed. When they came back from the war, he delivered her the marriage prefents 


\section{$\left[\begin{array}{lll}2 & 276 & ]\end{array}\right.$}

prefents in prefence of her father and his friends. By accepting them the match. was made, and on the day appointed for the wedding-feaft, when the will have the return for his gifts prepared, the will be made his for ever."

'And is whatI have heard true?' faid the fprightly friend of Agrippina, " that there is here no chance of a fecond hufband?'

" A fecond hurband!" cried the old woman with aftonifhment, "where fhould The find a fecond heart to beftow upon him? We have indeed heard that at Rome women have many hearts, or rather that by their conduct they fometimesappear tohave none; that there they commit adultery with impunity, and that, by a fomething called divorce, they even make adultery lawful. But thefe are flanders not to be credited of the great nation; nor am I fo fimple as to believe that women of exalted rank fhould ever degrade themfelves." 


\section{$\left[\begin{array}{lll} & 277 & \end{array}\right]$}

“ Would to the gods!" cried Agrippina, " that every Roman matron thought with you!"

The attendants of Agrippina were then ordered by their miftrefs to produce the ornaments the had felected as a prefent for the bride. Thefe confifted of a white robe, an embroidered girdle with a clafp, and a gold ring, fuch as were given by the Romans to their brides at the ceremony of betrothment. To thefe Paulina added the purple ribbon, which it was the peculiar privilege of modeft women to wear.

" The gifts are precious to me," faid the young German, " they thall be preferved in my family for ever. To the latelt generation they thall be handed down, as a perpetual memorial of the honour conferred upon our houfe by the daughter of. Agrippa."

'But you muft wear them yourfelf,' faid Agrippina, "they were intended as a wedding-drefs.'

" $\mathrm{No}, "$ 


\section{$\left[\begin{array}{lll}2 \pi & \end{array}\right]$}

"No," replied the young woman, "fuch gaudy ornaments are not befiting for a Gurman; I thould lofe the refpect of my hufband, did he think me capable of taking pleature in fuperfluous finery. $\mathrm{He}$ will glory in the gifts of the princers as the pledge of her friendhip, but he would bluh to fee me expofe myfelf by affecting to depart from the fimplicity of our nation."

Firm to her refolution the bride appeared on the day of her nuptials clad in the ufual attire. A chemife of blue and white linen without heeves defcen led to her feet, and being drawn tight round the waift by a band of the fame materials, difplayed her thape to advantage. Her long yeilow hair, braided on her fnowy forehead, was turned up behind, and faftened at the top by a bodkin of white thorn. Her fine complexion heightened by the blufh of modefty gave to her dark blue eyes a vivaciry, which, if it did not equal the brilliant luftre that fparkled in Agrippina's, was neverthelefs 


\section{[ $\quad 279$ ]}

neverthelefs expreflive and beautiful. At the entrance of the fmall lawn which furrounded the houfe, the received Agrippina and her friends, and conducted them to the feats prepared for them; from whence they could have a full view of the exchange of gifts which conftituted the marriage ceremony.

The companion of the young chief firft advanced with a yoke of oxen, which were given to the bride to remind her that the labours of the field were to be under her direction. Having driven the oxen to the Atalls prepared for them, the returned and was met by the brother of the bridegroom, leading in his hand a horfe fully caparifoned. " By accepting this horfe," faid he, "you declare your refolution of accompanying your huband wherever his fortunes may lead him. You are to be his companion in war, the partner of his toil and danger. You are to have but one country and one fate." 


\section{[ $\begin{array}{lll}280 & \text { ] }\end{array}$}

The bride liftened with attention, and by raking the reins and leading off the horfe evinced her acquiefcence. The bridegroom, who had been a pleafed fpectator of all that had hitherto paffed, now came forward. In his hands he held a fhield, a fpear, and a fword. "Thefe," fays he, " are the arms tranfmitted to me by my anceftors, they have for feven generations been by every chief of our family given to his bride, and faithfully kept by her till claimed by her eldeft fon. By my mother were they prefented to me in the midft of the affembled chiefs, and by this act the declared her life to be without ftain. Thefe arms are emblematical of the hurband's honour, which he commits in truft to the partner of his bofom. They come unto your hands unpolluted by a fingle ftain; be it your care to preferve the facred treafure, and to deliver it without fpot or blemin to the fon of our loves." 


\section{[ 281 ]}

The bride received the precious depofit with modefty, but firmnefs; and then in her turn prefented a helmet, a fhield, a fword, and javelin; which, as her father in a thort fpeech intimated, were intended to remind the hulband that he was to be the protector of his wife and family. The thield being of very curious workmanfhip attracted the attention of Agrippina; it was handed to her for infpection, and on a nearer view the found that it was compofed of ofier twigs, dyed of a variety of bright colours, and moft curioully platted, fo as to give in each of the four divifions a lively reprefentation of fome flower, or animal peculiar to the country in which the chief or his family had fignalized their valour.*

The feaft for the numerous company was profufely fpread; and was, as may be fuppofed, lefs remarkable for elegance

* This is confidered by antiquarians as the origin of coats of arms.

or 


\section{[ 282$]$}

or variety than for abundance. It had but juft commenced, when two ftrangers appeared, who from their drefs were known to belong to the Cattian nation. Neither their names or bufinefs were however asked. According to the German rules of hofpitality, they were conducted in filence to the feat of honour, on the right hand of the mafter of the houfe, and regaled with the molt dainty morfels.

There was fomething in the appearance of thefe youths which particularly attracted the attention of Agrippina. In the elder of the two an air of fuperiority was confpicuous; and the extreme delicacy of the features fuited fo ill with the complexion, as to create a doubt in her mind, whether it had not been embrowned by art. She had not yet among the barbarians feen a figure fo graceful, or a deportment fo dignified. Her curiofity was excited, and the filence of the ftrangers added to its force. Impatient of delay, he fent to the Ubian 


\section{[. $\begin{array}{lll}283 & 3\end{array}$}

chief to beg that he would enquire the name and rank of his extraordinary guefts. The old man appeared no lefs furprifed than morrified by her requet, and humbly entreated that the would not infift upon his difhonouring himfelf by a breach of hofpitality. It was then explained to her, that by the eftablithed cuftoms of Germany, to an the name of a ftranger was to imply a doubt of his right to your protection, and was therefore highly indecorous: nor was it proper for the ftranger rafhly to declare himfelf, fince whether he was the fon of a friend o: foe, he had an equal claim to attention.*

* The fpirit of hofpitalicy appears in the progrefs of fociety gradually to decreafe, in proportion as nations advance in refinement. "In countries," fays Montefquieu. "where the pecple move only by the fpirit of commerce, they make a traffic of all the humane and the moral virtues. The fentiments of the heart, the focial affections, and even the dues of humanity, are there to be obtained only for moncy." The fpirit of feltithnefs which extinguifhes that of hofpitality, is not corfined to commerce; it is the never-failing attend. ant on luxury and refinement.

While 


\section{[ 284 ]}

While Agrippina was holding this conference with her hoft, the ftrangers ap. peared to liften with intereft to all that paffed. The elder lifting his dark blue eyes which had hitherto been fixed upon the ground, darted on her a look of reproach, which affected her in the molt fenfible manner. Quickly entering into his feelings, the was afhamed of having indulged a curiofity which mult have appeared to him fo reprehenfible; nor could all the proud confcioufnefs of fuperiority prevent her from being fenfibly mortified at having violated the rules of propriety eftablifhed by a rude unlettered people.

Agrippina heard nothing more of the ftrangers for feveral days. She had in that time been agreeably furprifed by receiving an unexpected vifit from the wife of Caius Silius, a lady to whom from infancy the had been attached by ties of the fricteft friendfhip. Silius, who commanded one of the detached armies fationed on the frontiers, 


\section{[ $\begin{array}{ll}285 & \text { ] }\end{array}$}

frontiers, no fooner heard of the fituation of Agrippina, than he fent his wife guarded by a proper efcort to Ubiorum, to foothe by her prefence the lonely hours of her friend. Since the was thought worthy of that title, Sofia Galla could not have been deftitute of merit; the had already been endeared to Agrippina by many proofs of affection, and the kindnefs of the prefent vifit ferved to rivet every tie of mutual attachment.*

Sofia found the fituation of Agrippina much more tolerable than the could have imagined. Her houfe had been fitted up by the Roman artifans in a ftyle of neatnefs and comfort, and her apartments furnithed according to the Roman tafte. Here, foon after the arrival of Sofia, the was one morning, when engaged in converfation with her friend, furprifed by the fudden entrance of the two ftranger youths, who had at the marriage-feaft fo

* Note X.

much 


\section{[ 486 ]}

much attracted her curiofity. Obferving in their looks the appearance of perturbation and anxiety, the endeavoured to infpire them with confidence by the kindnefs of her reception. After a hort paufe, the elder thus addrefled her:-

"You are the wife of a Roman, but the praifes I have heard beftowed upon your virtue infpires me with confidence. I do not however expect that you fhculd protect me, without knowing to whom that protection is extended; for thofe of your nation underftand not the claims of the ftranger."

Agrippina eagerly affured him, that the knew how to refpect the rights of hofpitality, and that he might depend on her pro. tection. "My name is of no importance," refuned the Atranger, "but I will not impofe upon you in regard to my fituation. This garb which I and my companion have affumed, belongs not to our fex. You fee before you an unhappy female, 


\section{$\left[\begin{array}{lll}087 & 0\end{array}\right]$}

who flies from the vengeance of an offended father to the protecting arms of a beloved hulband.

"The chief from whom I fprung, and he to whom I have been united, are equals in rank and in renown. They long were friends, and when I gave my heart to the hero, my father fmiled upon our loves; but alas! no fooner did difcord enter into their councils, than he commanded me to withdraw my affections from him to whom they had irrevocably been engaged. Obedience was impollible; nor could I be unfaithful to my vows without tarnifhing my honour. My lover urged me to fulfil the promife that had once been fanctioned by duty, my heart impelled me to a compliance with his requeft; and at the moment when iny father lad promifed me in marriage to a chief who was of his party in the quarrel, I cloped with the object of $\mathrm{my}$ affection, and became his wife. 'The rage of an incenfed father ftill purfues me. 


\section{[ $\begin{array}{ll}288 & \text { ] }\end{array}$}

Taking advantage of my hufband's abfence, lie refolves to get me into his power. I have by means of this difguife fucceeded in efcaping from his emiflaries, and could I be concealed under your roof till midnight, fhould have no doubt of being fafe from their purfuit. I adjure you then by your love for the hulband you adore, to affit in faving a wretched wife from the miferics of an eternal feparation!"

Here the ftranger paufed; but though her voice was filent, her eyes continued expreffively to convey her feelings to the foul of Agrippina. True generofity is prompt in its decifions. Agrippina did not hefitate to promife the defired protection, and immediately conveyed her guefts to a place where they would be fecure from all intrufion.

At the dead hour of midnight, Agrippina, faithful to her word, attended the fugitives. She urged their remaining in their prefent place of fafety, till the hutband of 


\section{[ [ $\begin{array}{ll}989 & \text { ] }\end{array}$}

the ftranger fhould be informed where his wife was now concealed, and could come to take her under his own protection. But the propofal was declined, and the German heroine, having thanked her benefactrefs with tears of genuine gratitude, departed in the affured hope of meeting her beloved lord at an appointed place before the dawn of day. 



\section{ADDITIONAI.}

NoTTS.

\section{(A.) p. 66. - (в.) p. 70:-(c.) p. 84}

$A$ RE: confoliclated into the following thort A thetch of the lite of Marcus Antonius, commonly called Nark Antony, and after his coalition wiah Octavius and Lepidus, difiveguifhed by the appe'lation of triumvir. $16 \mathrm{e}$ are informed b. Plutarch, that "he wats the fon of Antony, furnamed the Cretan, a man of no figure or confequence in the political world; but difinguithed for his integrity, benerolence, and liberality. His mother's name was Julia; the was of the family of the Cefars, and a woman of ditinguifhed merit and modefty. Under her aupices, Mark Antemy receivcd lis education; when, after the death of 


\section{[ $\quad 292]$}

his father, the married Cornelins Lentulu=, whom Cicero put to death for engaging in the confpiracy of Catiline. This was the origin: of that lafting enmity which fubfifted between Cicero and Antony. The latter affirmed, that his mother Julia was even obliged to beg the body of Ciccro's wife for interment; but thiis not true, for none of thofe who fuffered on the fime occafion under Cicero, were refufed this privilege. Antony was engaging in his perfon, and was unfortunate enough to fall into the good graces and friendhip of Curio, a man who was devoted to every fpecies of licentioufnefs; and who, to render Antony the more dependent on him, led him into all manner of excefles. Of courfe, he was foon deeply involved in debt, and owed at least two hundred and fifty talents, while he was a very young man. Curio was bound for the parment of this money; and his father being informed of it banifhed Antony from his houfe. Thus dimiffed, he attached himfelf to Clodius, that peftilent and audacious tribune, who threw the ftate into fuch dreadful diforder; till weary of his mad meafures, and fearful of his oppo'nents, he paffed into Greece, where he emploved 


\section{[ 293 ]}

ployed himfelf in military exercifes, and the ftudy of eloquence. The Afiatic ftyle was then much in vogue, and Antony fell naturally into it; for it was correfpondent with his manners, which were vain, pompous, infolent, and affunning." Having obtained a command of cavalry, he made a campaign in Syria under Gabinius, where he diftinguifhed himfelf by his courage, no lefs than by his profufion and licentioufnefs. He after this returned to Rome, which was now divided between the two parties of Pompey and Cæfar. With Curio and other young men of defperate fortune he joined the party of Cafar, who fupplied then with the means of gratifying that unbounded prodigality which had rendered their circumftances fo embarraffed. In the wars of Cæfar againft the senate, Antony diftinguined himfelf in every battle that was fought, particularly in that of Pharfalia, where Pompey was defeated, and Rome reduced to fubjection. In the abfence of Cæa ar, Antony now governed Rome, and had a full opportunity of difplaying the talents in which he chiefly gloried. Every one who could difcover a new and unheard of extravagance, was fure of his farour and pro. tection. 


\section{[ 294 ]}

tection. But at is to be remarked that neither his prodigality to players and buffoons, nor his noted intemperance, nor even his chariots drawn by lions, gave fuch difguft to the people, as the till then unheard-of indecency of carrying about a miftrefs with an equipage as well appointed as that of his mather! He divoreed his wife Antonia to marry Fulvia the widow of Claudius, a worvan of high paftions, imperious, ambitious, and vindictive. It was to Fulvia, therefore, that Cleopatra was obliged for teaching Antony due fubmiffion to female authority. He had gone through fuch a couri: of difcipline as made him perfectly tractable when he came into her hands.

On the death of Cæfar, having gotten poffeflion of his treasures and privatc papers, he put himfelf at the head of the party, defpifing the youth of OAtavius, who was then only eighteen ycars of age, and who appeared inclined to $t-$ poufe the caufe of the fenate; by tis promiles deceiving Cicero and all who entertained any hopes of the reftoration of the conftitution. Anteny and Oetarius foon faw it their mutual intereft to come to an underftanding: and heing joined by Lepidus who was the commander 


\section{[ 295 ]}

of a third army, they met in a fmall ifland not far from Bologna, and divided between them the empire of the world like a paternal inheritance; whom they hould fpare and whom they fhould deftroy, it was not fo eafy to adjult. Whi e each was for faving his refpective friends, and putting to death his enemies. At length their refentment againft the latter overcame their kindnefs for the former. Octavius gave up Cicero to Antony, and Antony facrificed his uncle to Octavius; while Lepidus had the privilege of putting to death his own brother Paulus! Never was any thing fo atrocious, or fo execrably favage as this commerce of murder; having marked down fuch as they intended to put to death, (in number three hundred) they cemented their confederacy by the alliance of Octavius with Claudia the daughter of Fulvia. The murder of the great Cicero was the firft fruits of this infamous coalition, which was followed by a fcene of blood and rapine not to be defcribed. Having thus fatiated the paffions of ararice and revenge, Antony proceeded to take poffeffion of the provinces allotted to him in the eaft; where in Cleopatra he might truly be firid to mect with a congenial nuind. This 


\section{[ 296 ]}

feducing and voluptuous beauty, who had captivated the hearts of Cæfar and of Pompcy, war retolved that Antony thould not efeape her chains. She foon obtained the moft abfolute dominion over his affections, and induced him to make a facrifice of honour and even of amhition to fenfuality. Fulvia, in hopes of withdrawing him from her dangerous rival, fet out from Rome, but died by the road; and by her death made way for his marriage with Octaria, the eldeft fifter of Octavius, which was celebrated foon after his return to Rome.

Octaria was the widow of Marcellus, a man of high rank and great reputation, by whom the had one fon and three daughters; but the was rounger than Cleopatra, equalled her in treauty, and was as remarkable for the poffertion of every virtue, as her rival was odious for very crime. She had one daughter by Antony called Antonia, who was after marrice? to Drufus the fon of Livia; but his chiluren by Fulvia were no lefs the objects of her maternal care. The purity of Oetavia's mind Wid not fuit the diffolute Antony, who, in reaning his infamous connection with Cleopa\%. compleated his ruin. Octaria wa long the 


\section{[ $\left.\begin{array}{lll}297 & \text { ] }\end{array}\right]$}

the peace-maker.between her lufband and her her brother. "The eyes of all," faid the, "upon an occafion of this nature, are necetfarily turned on me, who am the wife of Antony and the fifter of Cxfar; and fhould thefe chicfs, mifled by hafty counfels involve the whole in war, whatever may be the event, it will be unhappy for me." Antony's injurious treatment. of fuch a woman excited general indignation; and the diftribution he made of the provinces that had been conquered by the Roman arns: to his children by Cleopatra, increafed the public difcontent. While Antony continued to wafte his giddy hours in every fpecies of luxuryand diffipation with her abandoned rival, Oetaria deroted herfelf to the case and chucation of his children; nor after he harl paid the forfeit of his folly and his crimes at the battle of Actium, did his virtuous widow fortake the charge of his unhappy orphans. Ot his two fons by Fulvia, the elder was inled put to death by Octurius; but Luribs the rolmger was bronght up with the clildien of Oetaria, and marred we dangher liachla. a reluted in the test. 


\section{[ 298$]$ \\ (D.) p. 85.-Ovation}

Was an inferior fpecies of triumph, in which the general entered the city, not in a triumphal chariot, but on foot, or on horfeback, crowned with myrtle; and inftead of a bullock, facrificed a fheep.

\section{(F.) p. 95 .}

The paffare alluded to, is thus translated by $\mathrm{D}_{\mathrm{R}} \mathrm{YDEX}$ :

" ENEAS here bcheld, of form dirine,

"A godlike youth in glitt'ring armour hine,

"With great Marcellus keeping equal pace;

"But gloomy were his eyes, dejected was his face.

" He faw, and wond'ring, afk'd his airy guide,

"What, and of whence, was he who prefs'd the

" hero's fide?

"His son, or one of his illuftrious name:

"How like the former, and almoft the fame!

" Obferve the crowds that compafs him around;

" All gaze, and all admire, and raire a thouting found.

" But hov'ring mifts around his brows are fpread,

"And night with fable thades involves his head.

"Seek not to know (the ghoft reply'd with tears)

" The forrows of thy fons in future years.

"This youth (the blifful vifion of a day)

"Shall juft be fhewn on earth, and fnatch'd awar.

"'The gods too high had rais'd the Roman fite:

" (Were but their gifts as permanent as great!)

"What 


\section{[ $\left.\begin{array}{ll}299 & \text { ] }\end{array}\right]$}

5i What groans of men Mall fill the Martian field!

"How frerce a blaze his flaming pile fhall yield!

" What fun'ral pomp' thall floating Tyber fee,

"When riling from his bed he views the fad folem" nity!

"No youth fhall equal hopes of glory give;

" No youth afford fo great a caufe to grieve.

"The Trojan honour, and the Roman boaft;

"Adnir'd when living, and adorn'd when loft!

"Mirror of ancient faith in carly youth!

"Undaunted worth, inviolable truth!

"No foe, unpunill'd, in the fighting field

"Shall dare thee foot to foot with fword and hield;

"Much lefs in arms oppofe thy matchlefs force,

"When thy fharp fpurs thall urge thy foaming horfe.

"Ah, hould't thou break thro' face's fevere decree;

"A new Marcellus thall arite in thee!

" Full cinifters of fragrant lilies bring,

"Mix'd with the purple rofes of the finging:

" Let mo with fun'ral fiow'rs his body itrow;

"This grift which parents to their children owe, $\}$

"This unarailing gift at leat I may beftow!"

$$
\text { (G.) 1\% } 10 \% \text {. }
$$

The exact period of wir Saviour's birth has been a matter of dipute to the commentators, fome afferting it to have taken place three and others four years, before that which is commonorated be the Christim world as the rear 


\section{[ 300 ]}

of our Lord. But as the exact time of the crent is of no real importance, the vulgar ara has been in the text adopted.

\section{(H.) p. 109. \\ Virgines Vestales.}

"Virgins confecrated to the worlhip of Vefta, a priefthood derived from Alba; for Rhea Sylvia, the mother of Romulus, was a veftal originally from Troy, Virg En. xi. 290. The veftal virgins were chofen firf by the kings, and after their expulfion by the Pontifex Maximus; who, according to the papian law, when a vacancy was to be fupplied, felected from among the people twenty girls above fix and below fixteen years of age, free from any bodily defeet, whofe father and mother were both alive, and free-born citizens. It was determined by lot in an affembly of the people, which of thofe twenty thould be appointed. Then the Pontifex Maximus went and took ber on whom the lot fell, from her parents. The Pontifex Maximus might choofe any one he thought proper, with the confent of her parents. and the requifite qualifications. The vetal 


\section{[ 301 ]}

virgins were bound to their miniftry for thirty years. For the firlt ten they learned the facred rites; for the next ten, they performed them; and for the laft ten, they taught the younger virgins. The oldeft was ealled Maxima. After thirty years fervice they might leave the temple, and marry; which, however, was feldom done, and always reckoned ominous.

The office of the veftal virgins was, ift, in keep the facred fire always burning, watching it in the night-time alternately, and whoever allowed it to go out was feourged. This accident was always efteemed unlucky, and expiated by offering extraordinary facrifices. The fire was lighted up again, not from another fire, but from the rays of the fun; in which manner it was renewed every year on the lft of March, that day being anciently the beginning of the year.- Ed, To kecp the fecret pledge of the empire; fuppofed to have been the palladium or the penates of the Roman people, kept in the imnermoft recefs of the temple, vifible only $t / 2$ the virgins, or rather to the Veftales Maxima alone; fometimes removed from the temple of Veftaby the virgins, when tumult and llaughte: frevailed in the city, or in cafe of a fire. Their 


\section{[ 302 ]}

prayers and vows were always thought to have great influence with the gods. In their devo tions they worfhipped the god Falcinus to guard then from envy. The veftal virgins wore a long white robe, bordered with purple; their heads were decorated witli fillets, and ribbons. When firtt chofen, their hair was cut off and buried under an old lotes or lote tree in the city, but it was afterwards allowed to grow. The veftal virgins enjoyed fingular honours and privileges. The pretors and confuls when they met them in the ftrect, lowered their fafces, and went out of the way to hew them refpect. They had a lictor to attend them in public, at leat after the time of the triumvirate; Plutarch fays always. They rode in a chariot, fet in a diftinguifhed place at the fpectacles; were not forced to fivear, unlefs they inclined, and by none other but Vefta. They might make their teftament, although under agre; for they were not fubject to the power of a parent or guardian, as other women. They could free a criminal from punifhment, if they met him accidentally, and their interpofition was always greatly refjected. They had a falary from the public. They were held 


\section{[ 303 ]}

in fuch veneration, that teftaments and the moft important deeds werc committed to their care, and they cnjoyed all the privileges of matrons who had three children.

"When' the veftal virgins were forced thro" indifpofition to leave the Atrium Veste, probably a houfe adjoining to the temple, and to the palace of Numa, it not a part of it, where the virgins lived, they were entrufted to the care of fome venerable matron. If any veftal violated her vow of chaftity, after being tried and fentenced by the Pontifex, Mhe. was buried alive with funeral folemnities, in a place called the Campus Sceleratus, near the Porta Collina; and her paramour fcourged to death in the Forum; which method of punifhment is faid to have been firft contrived by Tarquinius Prifcus. The commiffion of this crime was thought to forbode fome dreadful calamity of the ftate, and therefore was always expiated with extraordinary facrifices."

Adams's Antiquities.

$$
\text { (I.) p. } 113 .
$$

The toga was a loofe woollen robe which covered the whole body; round, and clofe at 


\section{[ 304 ]}

the bottom, but open at the top down to the girdle, and without fleeves. None but Roman citizens were pernitted to wear the toga, and banifhed perfons were prohibited the ufe of it. The colour of the toga was white, except in mourning, when it was changed for one of black or fome dark colour. Under the toga was a veft or tunic, with or without fleeves, as the fathion varied. Young men when they affumed the toga, or manly robe, received from their parents a tunic, embroidered in a particular manner. This change of drefs took place at the age of 16 or 17 , and was deemed an event of great importance to the Roman youth, form. ing a fort of new æra in their exiftence.

$$
\text { (к.) p. } 119 .
$$

The pelcinar appears to have been a fom of balcony commanding a view of the circus, the place appropriated to the horfe and chario races, fighting of wild beafts, \&ic. The ciranfian games here mentioned were infituted by Julius Cafar, to be celebrated annually on the 4th or 5th of April; and to him did the populace owe the marnificent edifice of the cirms; 


\section{$\left[\begin{array}{lll}305 & 1\end{array}\right.$}

mile in circumference, and furrounded with porticos three ftories high. Before the games began, the images of the gods were led along in procefion on carriages, or on men's flould. ers, with a great train of attendants, fome on horfeback and fome on foot. Next followed the dancers, muficians, Eic. When the procelfion was over, the confuls and priefts performed facred rites. The thews exhibited were chariot and horfe races, wild leafts fighting with one another, or with men, who fometimes undertook to amufe the fiectators with this favage fport roluntarily for live; but as $f(\mathbb{w}$ could be bronght thus to ritk their lives of their own accord, the number wanted to fumifh out the entertainment was fupplice from thofe who had becu condenned to punifment for real or imputed erimes!

Contefts of agility and ftrength, as ruming, leaping, boxing, Exc. were likewife eshibited at the circus.-Adams's Antigitities.

Frequent allufions to thefe farourite amufements are to be met with in the writing of $\mathrm{St}$. Paul, as in 1 Cor. ix. 24.; x. $32 . ;$ Lph. ri. 11.
rot. I.
$x$
(1.) p. 1:1 


\section{[ 306 ] \\ (L.) p. 121.}

Claudius is reprefented by Suctonius as hav. ing becn, cren after the expiration of his minority, under the direction of a pedagngue, of whom he complained that "he was a barbarous wretch, and formerly a mafter mule-driver, that was retained as his governor, on purpofe to correct him fererely on every trifling occation." By another writer, he is faid to have had the historian Salluet for his preceptor. Be this as it may, his manners and apnearance were fo little flattering to his family, that "when he aftumed the manly robe, he was carried in a chair at midnight into the capitol, without the winal ceremony."-Suet.

$$
\text { (a.) P. } 130 \text {. }
$$

sempronius Gracchus is reprefented by Taints as "detcended from a noble fanily; a rar poftedid of thents, and atomed with elo.

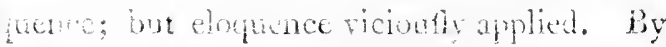
he wat and accomplithmont: he feduced

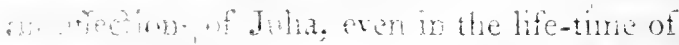
ichand Agripa. Nor did his pation there: wen the wat afterwardonarmed to 


\section{[ 307 ]}

Tiberius; he was ftill a perfevering adulterer, and by fecret artifices poifoned the mind of the wife againft her hurband. The letter to Auguftus, in which the treated the character of Tiberius with contempt, was gencrally thought to be his compofition." This was an offence which could never meet with forgivenefs from wounded pride.

After pafling fourtecn years in difmal folitude in an ifland on the coaft of Africa, he met his death from the hands of affaffins, fent by Tiberius to difpatch him. His appearance was fuch as to excite compaffion cren from his murderers. The gay feducer of Julia is reprefented by Tacitus as having been found by his affaffins " ftanding on the point of a prominent neck of land, with a countenance fixed in forrow and defpair. As foon as the ruffians approached, he required a fhort delay that he might write the fentiments of a dying man to his wife Alliaria. Had this memorial of his regret and penitence been preferved, it would probably have afforded a convincing proof of the power of confcience, and might have been of fome ufe in deftroying thofe dangerous Illufons, "hich lead to a belief in the all conquering 


\section{[ 308 ]}

quering power of iove. After fourtecn year: of exile Sempronius thought no longer of his mitrefs; but even in the hour of death his unfortunate wife was remembered with tender-. nefs and affection. Haring performed this laft duty, he retumed his fortitude, and calmly prefented his neck to the murderer"s ftroke, "in his laft moments," fay's the hiftorian, "worthy of the Sempronian name!"

$$
\text { (o.) and (P.) p. } 161 \text {. }
$$

There is no article in which the Romans appear to have been more extravagantly luxurious, than in the number and fize of their villas. Pling has left a particular defcription of feveral that belonged to him; particularly of that in Tufcany, which feems to have been bis principal feat. The apartments are by many fuppofed not to have been all under one roof, but feattered about in different parts of the garden, and united with each other by covered porticos. To thofe who are macquainted with the fubiect, the following account of the inal. left of thefe villas, may nut be altogether unarceptable: 


\section{[ 309 ]}

"My villa is large enough to afford conveniences, without being extenfive The porch before it is plain, but not mean, through which you enter into a portico in the form of the letter $\mathrm{D}$, which includes a fmall, but agreeable area. This affords a rery commodions retreat in bad weather, not only as it is inclofed with windows, but particulaily as it is theltered by an extrandinary projection of the roof From the midalle of this portico you pars into an inward court extremely pleafant, and from thence into a handfome hall which runs cut towards the fea; fo that when there is a fouth-weft wind, it is gently wathed with the waves, which fpend themfelves at the foot of it. On ewery ficic of this hall, there are either folding.. doors or windows equally large; by which means you have a view from the front and the two fides as it were of three different leas. From the back part you fee the middle court, the portico, and the area; and by another view you lork through the portico into the forch, from whence the profpect is terminated by the woods and mountains, which are feen at a diftance. On the lsfi-hand of this hall lies a large drawing-room; and byond that a fecond 


\section{[ 310 ]}

cond of a fimaller fize, which has one window to the rifing and another to the fetting fun; this has likewife a profpect of the fea, but bcing at a greater diftance, is lefs incommoded by it. Contiguous to this is a room forming the fegment of a circle, the windows of which are fo placed as to receive the fun the whole day: in the walls are contrived a fort of cafes, which contain a colletion of fuch authors, whofe: works can never be read too often. From hence you pats into a bed-chamber through a paffage, which being boarded and fufpended as it wcre over a ftove, which runs underneath, tempers the heat which it receires and conveys to all parts of this room. The remaining fide of the houfe is appropriated to the ufe of my flaves and freed-men; but, however, moft of the apartments in it are fufficiently neat to entertain any of my friends, who are inclined to be my guefts. In the oppofite wing is a room ornamented in a very elegant taftc; next to which lies another room, which, though large for a parlour, makes but a moderate dining-room. Beyond this is a bed-chamber together with its anti-chamber, the height of which renders it cool in fummer, as its being fhelteres? 


\section{[ 311 ]}

Aneltercd on all fides from the winds makesit warm in winter. To this apartment another of the fame fort is joined by one common wall. From thence you enier into the grand and fpacious cooling-room belonging to the baths, from the oppofite walls of which two circular bafons project, large enongh to fwim in. Contiguous to this is the perfuming-room, then the fweating room, and beyond that the furnace which conveys the heat to the baths: adjoining are two other little bathing-rooms, which are fitted up in an clegant rather than coftly manner. Annexed to this is a warm bath of extraordinary workmanthip, wherein one may fwim, and have a profpect at the fame time of the fea."

The reft of the defcription is too long for infertion; it muft, however, be obferved, that though Pliny profefles only to deferibe a part of this small villa, he gives in that part a litit of more than forty rooms!

$$
\text { (Q.) } 11.173 \text {. }
$$

When the rites of paganifm gave place to a purer fyftem, the gods of filver and of brafs were neceffarily banifhed from the tables of all wholnad enbraced the doctrines of Chritianity, but 


\section{$\left[\begin{array}{ll}312\end{array}\right]$}

but the focial meal was ftill held facred; and when the families of believers aftembled at the focial board, they were remincled of the prefence of the true aud invifible God br a fo. lemn invocation of the Deity. At the conch. fion of the repaft, the Divine Being whom they acknowledged as the giver of all good, was again addrefled with feelings of fuitable reverence and gratitude: and as gratitude and love to Gon were united in the mind of every true chriftian with benevolence and charity to man, thofe who had abundance did not forget upon thefe occafions to diftribute to the wants of the deftitute. The cufrom of confecrating every meal by akking a bleffing and returning thanks contiuned almoit to our own times to be very generally obferved, and is not as yet entirely fallen into difufe. May thofe who ought to fei the example prevent its ever bscoming obfoletc!

$$
\text { (ii.) p. } 174 .
$$

The foilowing very ingenious arrouments are adduced by Mliny, is an apolingy for thus reading what he intended for pubication:- "It is not," fays he, "whilft I am reading, but when I am real, that I aim at approbation; asd 


\section{[ 313 ]}

and for that reafon I omit no fort of method that can render my performances more correct. In the firlt place, I frequently revife my compofitions in private; afterwards I read them to two or three friends, and then give them to others to make their remarks. If after this I have any doubt concerning the juftnefs of their oblervations, I carefully weigh them again with a friend or two; and laft of all, I recite then to a more numerous affembly. This is the time, believe me, when I find myfelf beft able to cxercife all the feverity of the moft rigid criticifm, for my attention rifes in proportion to my folicitude; as nothing fo much awakens the judgment, as that reverence and modeft timidity which one feels upon thofe occafions. I never recite my works publicly, but only before a felect number of friends, whofe prefence I refpect, and whofe judgment I value; in a word, whofe opinions I obferve as if they were fo many individuals I had feparately confulted, at the fame time that I itand as much in fear of them, as 1 fhould of the moft numerous affembly. What Cicero fays of compofing, will, in my opinion, hold true of that awe we have of the public. It is the moft rigid eritic imaginable. 


\section{[ 314 ]}

imaginable. The very thoughts of reciting, the notion of entering an affembly, and the reverential concern when one is there; each of these circmuftances tend to improve and perfect an author's performance. Upon the whole, therefore, I cannot repent of a cuitom which I have experienced to be fo exceedingly beneficial; and am fo far from being difcouraged by the trifling objections of these censors, that I beg you would point out to me, if there be yet any other method of correction, that I may ald to this; for nothing can fufficiently fatisfy my care to render my compofitions finithed. I reflect, what an arduous undertaking it is to refign any work into the hands of the public; and I cannot but be perfuaded, that frequent and many confultations mult go to the finifhing of a performance, which one defires the world fhould univerfally and for ever admire." $-l^{\prime} l i$ ny's Epistles, vol. ii. p. 459.

$$
\text { (s.) p. } 189 \text {. }
$$

The triumphal robe was of purple, enriched with embroidcry in gold and filier, in the form of palm branches. It was worn over an embroidered tmic, ormanented in a manner equally fuperb.-Adems's antigutities. 


\section{[. 315$]$ \\ (T.) p. 201.}

The triumph of the fellin orer the focial principle appears in no inftance more firiking than in the defertion of infunts; a praftice fo, very common among the heathens, as ncither to have excited furprife nor abhorrence. The number of helplefs little innocents that wert expofed to perish, exceeds what could be believed, were the fact not afeertained by the bet? authorities : nor was any attempt inade to fave or to provide for thefe deftitute beings, till the benevolent fpirit of Christianity cxpanded the human heart; and by giving a lighther view of the dignity of human nature than philofophy had ever taught, exalted all that bore the human form into objects of tendernefs and love.

$$
\text { (v.) 1. } \simeq 60 \text {. }
$$

From the time of Acrippina's retiring to Ubi. orum Oppidum, till her return to the Roman camp, the only event recorded by the hiftorians is the birth of her daugbter. But though her part in the feenes that are in this chapter introduced, is merely conjectural, the defcription of Gcrman manmers will be found fo exaity to corsefpond 


\section{[ 356$]$}

comejont with that giren by Tucitus, that tine picture may be depended upon as gennine. The adrentures of Thufneida are related like. wite by the Roman hiftorian in nearly the fame woms as the is reprefented relating them to Agrippina; and therefore, tho the intervitw between the German heroine and the Roman princes may nerer actually here taken place, the tuth of hiftory cannot properly be faid to have been violated. Who now believes that the long foeches which the hiforians bave thouglat fit io put into the months of their prinecs and warriors were ever polin? Are they not univerfally confdered as a medium of Whefration, more animated and therefore more impreflec than any other mode in which the the fme idea could have been convered? All that the critic requires, is, that nothing fould be the introduced wheh is not frictly cheraneritic.

$$
\text { (i) p. } 069 \text {. }
$$

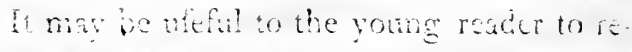
mork, that whe the reafoning faculty is, cither from wait of cultration, 3 is in the farage

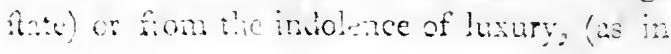




\section{$\left[\begin{array}{lll}317 & ]\end{array}\right.$}

the renned) permitted to lie chmant, the mind muft necelfarily be impellat to feck relief trom the wretclednets of racuity, by watersuncans it can be procured. To the perfon deftitute of intermal refources, the doom of earning his bread by the fiveat of his brow is in reality a bleffung. Confiant emplowent on the objects of perception, if it do not inuch expand the reafoning powers, is in fo far favourable to their improvement, as it lieeps the pafions in fubjection, and gives a conftant exercife to the faculty of attention. Which. where it has no fuch opportmities of exertion, nialt be awakened by the aid of poiverfal ftimulants. Hese, $a$ in many inftances, the extremes of barbarifn and of cirilization may be obferved to ancet. Idienets is conflicued as his pecultia prisilege by the farage as much as by the fine gentleman: but idlencis mut noceitarily produce emmi; and to get rid of fucla a trouble fone companion, the fame devices feent to have occured to both. "To derote," fays Tacitus in his aceount of the Germars, "both day and night to deen drinking, is a difgrace to no nan; thi-

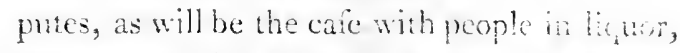

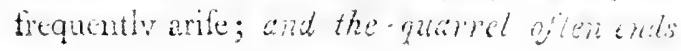




\section{[ 318 ]}

in scenes of blood! Even without the exercife of liquor, in their fober moments, ftrange as it may appear! they have recourse to dice, as to a scrious and regular business, with the molt defperate fpirit committing their whole fubftance to chance; and when they have loft their all, putting their liberty, and even their perions upon the laft hazard of the dye! Such is the effect of a ruinous and inveterate habit! They are victims to folly, and they call themfelves men of honour!"

Unfortunate men! yet who fhall fay that they were without excufe. The light of fcience had never beamed on their benighted minds,

" Tair knowledge to their eves her ample page,

" Rich with the fpoils of time, did ne'er enroll."

They were neceffirily, and not by choice, without olject or purfuit that was capable of siving constant and anple employment to all the glorions facultes, with which nature had entoved them. For the barbarian, therefore, lome apology may be made.

$$
\text { (x.) } 9.985 .
$$

Thether Sufia Gullat the wife of Silius, was rutin of Afinius Gallus, docs clcarly appear; 


\section{[ 319 ]}

appear; but the part he took on a future occio fion, when the unfortunate Sofia was, on account of her friendthip for Agrippina, perfecuted by Tiberius, leaves no room to doubt of their being connected; Afmius Gallus, by his marriage with Viptania, was now the brother-inlaw of Agrippina. If Socia was his filur, the was the daughter of Afinius Pollio, the difsinguifhed orator and confidential friend of Augutus, whofe name has been immortalized by Horace and Virgit. Pollio's intimacy with Anguftus muft have introluced his children, erein in infancy, to the acquaintance of Agrippins. Hence, perhaps, the origin of that firong atachment which they had for ach wher. 






University of California

SOUTHERN REGIONAL LIBRARY FACILITY

405 Hilgard Avenue, Los Angeles, CA 90024-1388 Return this material to the library from which it was borrowed.

$\frac{2}{10}$

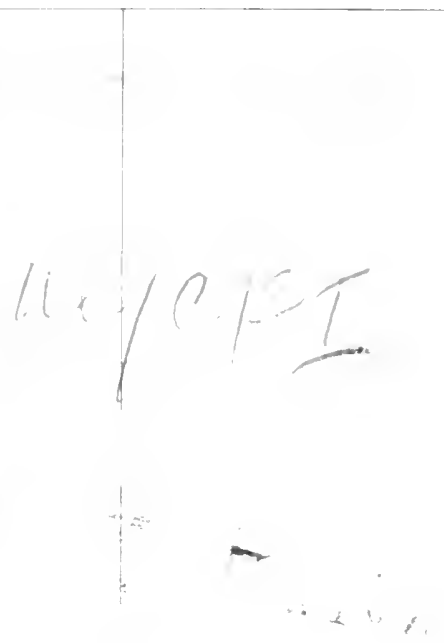

241: 


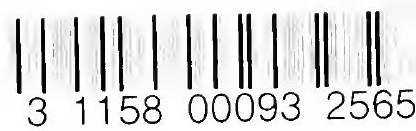

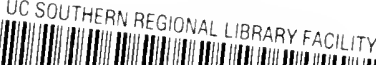
$A A \quad 000102802$ | AA 0001028026 
